Débora Mendonça Cardador Corrêa da Costa

\title{
Um olhar crítico sobre o projeto de interfaces tangíveis baseado na Engenharia Semiótica
}

\begin{abstract}
Tese de Doutorado
Tese apresentada como requisito parcial para obtenção do título de Doutor pelo Programa de Pós-Graduação em Informática da PUC-Rio.
\end{abstract}

Orientador: Prof. Hugo Fuks

Rio de Janeiro

Abril 2014 
Débora Mendonça Cardador Corrêa da Costa

\title{
Um olhar crítico sobre o projeto de interfaces tangíveis baseado na Engenharia \\ Semiótica
}

\begin{abstract}
Tese apresentada como requisito parcial para obtenção do título de Doutor pelo Programa de PósGraduação em Informática da PUC-Rio. Aprovada pela Comissão examinadora abaixo assinada.
\end{abstract}

Prof. Hugo Fuks

Orientador

Departamento de Informática - PUC-Rio

Profa. Raquel Oliveira Prates

UFMG

Profa. Thais Helena Chaves de Castro

UFAM

Profa. Clarisse Sieckenius de Souza Departamento de Informática - PUC-Rio

Profa. Simone Diniz Junqueira Barbosa

Departamento de Informática - PUC-Rio

Prof. José Eugenio Leal Coordenador Setorial do Centro Técnico Científico - PUC-Rio

Rio de Janeiro, 07 de Abril de 2014 
Todos os direitos reservados. É proibida a reprodução total ou parcial deste trabalho sem autorização da universidade, do autor e do orientador.

\section{Débora Mendonça Cardador Corrêa da Costa}

Graduou-se em Licenciatura em Matemática pela Universidade de Brasília (UnB) em 1986. Obteve em 1990 o título de Mestre em Sistemas de Computação pelo Instituto Militar de Engenharia (IME). No mesmo ano concluiu sua especialização em Matemática Aplicada à Computação pela Universidade Federal Fluminense (UFF).

Ficha Catalográfica

Costa, Débora Mendonça Cardador Corrêa da

Um olhar crítico sobre o projeto de interfaces tangíveis baseado na Engenharia Semiótica / Débora Mendonça Cardador Corrêa da Costa ; orientador: Hugo Fuks. - 2014

$108 \mathrm{f}$ : il. (color.) ; $30 \mathrm{~cm}$

Tese (doutorado)-Pontifícia Universidade Católica do Rio de Janeiro, Departamento de Informática, 2014.

Inclui bibliografia.

1. Informática - Teses. 2. Interfaces tangíveis. 3. Projeto de interfaces de usuário. 4. Prototipação. 5. Engenharia semiótica. I. Fuks, Hugo. II. Pontifícia Universidade Católica do Rio de Janeiro. Departamento de Informática. III. Título. 
Para minha amada Bianca. 


\section{Agradecimentos}

Agradeço a Deus por estar sempre comigo. Minha gratidão a Ele é constante e maior do que posso expressar.

A minha filha Bianca pelos beijos e sorrisos.

Aos meus pais e minha família pelo amor, compreensão e apoio, sem os quais este trabalho não existiria.

Meu mais profundo agradecimento ao Prof. Hugo Fuks pelo o privilégio de tê-lo tido como meu orientador. Agradeço pelo interesse, pelas orientações, pelo apoio, a paciência, o incentivo e, sobretudo, pela amizade durante os anos de doutorado.

Aos meus professores, em especial, à Profa. Clarisse Sieckenius de Souza por ter me introduzido ao mundo da Engenharia Semiótica e pelas muitas contribuições para este trabalho, feitas sempre com interesse e paciência.

À Profa. Simone Barbosa pelo suporte e contribuições para este trabalho.

Aos meus companheiros Kátia Vega, Wallace Ugulino e Bruno Gadelha pela amizade que só os anos juntos num doutorado podem forjar, pelas conversas, risos e muitos cafés que tornaram tudo melhor.

Aos meus colegas do laboratório SecondLab, pelo suporte e contribuições para esta pesquisa.

A toda a equipe do DI pelo apoio, convívio e profissionalismo, que criam um excelente ambiente para seus alunos.

A todos vocês agradeço por terem, de alguma forma, tornado meus anos como aluna de doutorado na PUC uma das melhores épocas da minha vida.

Agradeço também à PUC-Rio e ao CNPq por terem tornado meu sonho de fazer doutorado uma realidade. 


\section{Resumo}

Costa, Débora Mendonça Cardador Corrêa; Fuks, Hugo. Um olhar crítico sobre o projeto de interfaces tangíveis baseado na Engenharia Semiótica. Rio de Janeiro, 2014. 108 p. Tese de Doutorado Departamento de Informática, Pontifícia Universidade Católica do Rio de Janeiro.

Com a incorporação de recursos computacionais aos elementos físicos, a computação evolui para a ubiquidade e está presente nos elementos do ambiente físico. Casas, móveis e objetos do dia-a-dia, isto é, o ambiente que nos cerca, são as novas interfaces com as quais as pessoas interagem para colaborar e se informar. Essas novas interfaces implicam em um novo paradigma de interação, ainda pouco conhecido e explorado, como é o caso das Interfaces Tangíveis (Tangible User Interfaces - TUIs), que usam artefatos físicos para representação e controle de informações digitais. Desenvolver Interfaces Tangíveis requer combinar o trabalho voltado para o concreto (forma) com a abstração característica do desenvolvimento de software (comportamento). Este trabalho propõe um método denominado Prototipação Colaborativa de Tangíveis Baseada na Engenharia Semiótica, que combina as abordagens de prototipação e da Engenharia Semiótica no projeto de interfaces tangíveis. Ao combinar estas abordagens, o método agrega os benefícios da experimentação continuada de forma estruturada proporcionada pela prototipação com as vantagens do foco na comunicabilidade da Engenharia Semiótica no projeto de tangíveis. Um estudo de caso é conduzido a fim de investigar a contribuição do método proposto para incorporação da perspectiva da Engenharia Semiótica ao projeto de interfaces tangíveis.

\section{Palavras-chave}

Interfaces Tangíveis; Projeto de Interfaces de Usuário; Prototipação; Engenharia Semiótica. 


\section{Abstract}

Costa, Débora Mendonça Cardador Corrêa; Fuks, Hugo (Advisor). A critique of tangible user interface design based on Semiotic Engineering. Rio de Janeiro, 2014. 108 p. PhD Thesis - Departamento de Informática, Pontifícia Universidade Católica do Rio de Janeiro.

With the embedding of computing resources into physical elements, computing is moving toward ubiquity (or pervasiveness) and is present throughout the physical environment. Homes, furniture, and everyday life objects are the interfaces with which people now interact. Such new interfaces harbinger a new interaction paradigm that is little known and exploited to date, such as Tangible User Interfaces (TUIs) that use physical artefacts for representing and manipulating digital information. Developing TUIs means acknowledging both concrete (form) and abstract (behavior) aspects of an interface. This work proposes a method called Collaborative Tangible Prototyping Based on Semiotics Engineering that combines prototyping and Semiotic Engineering approaches to tangible interfaces design. By combining these approaches, the method brings together the benefits of continued structured experimentation provided by prototyping with the advantages of a focus on communicability from Semiotic Engineering for designing tangibles. A case study is conducted to investigate whether the proposed method contributes to incorporate the Semiotic Engineering perspective in the design of tangible user interfaces.

\section{Keywords}

Tangible User Interface; User Interface Design; Prototyping; Semiotic Engineering. 


\section{Sumário}

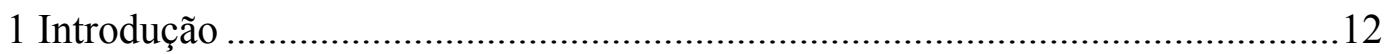

1.1. Questão, objetivo e método de pesquisa ................................................16

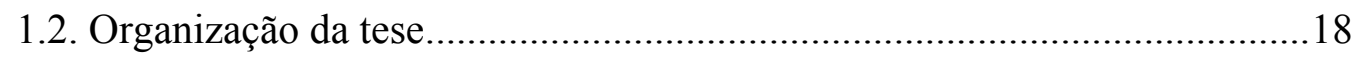

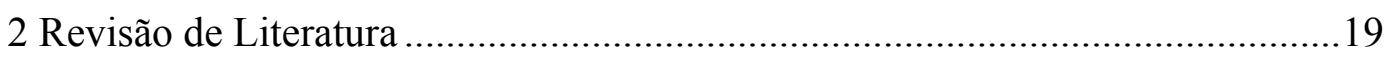

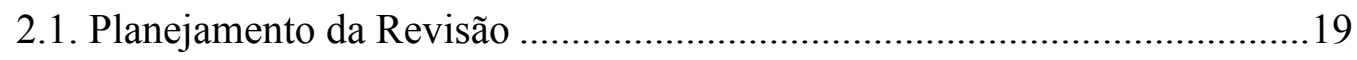

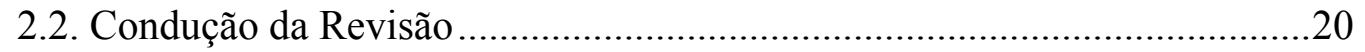

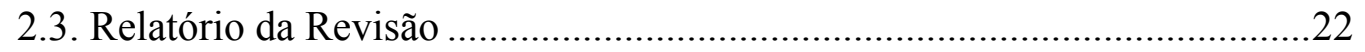

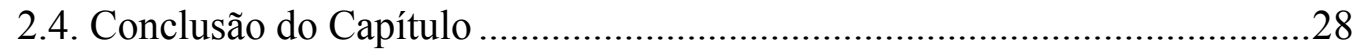

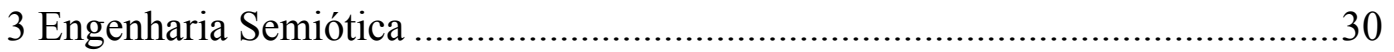

3.1. Projeto e Avaliação de interfaces baseados na Engenharia Semiótica ........32

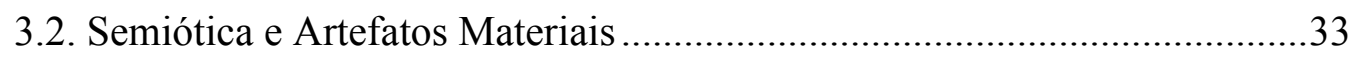

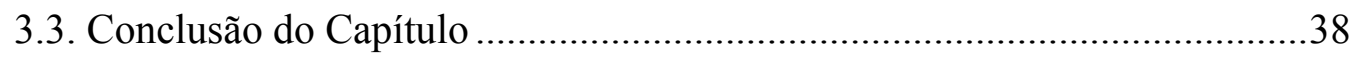

4 Prototipação Colaborativa de Tangíveis Baseada na Engenharia Semiótica......41

4.1. Preparação para Aplicação do Método ..........................................................46

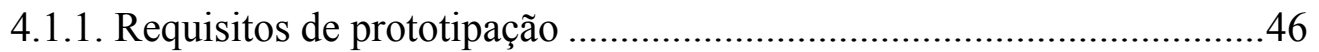

4.1.2. Conceitos de Engenharia Semiótica, orientações, formulário e esquema geral para elaboração da Metamensagem........................................48

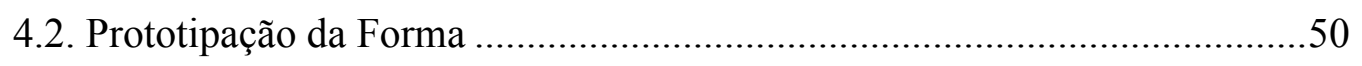

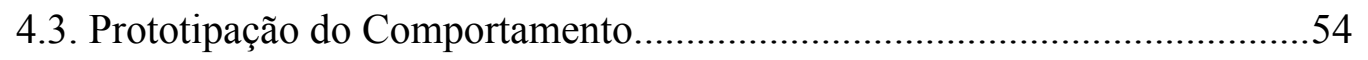

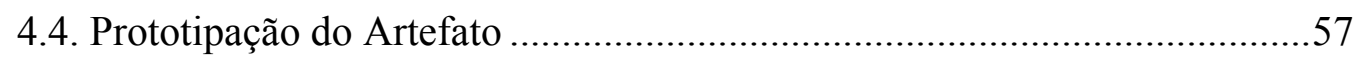

4.4.1. Análise Inicial do Artefato pelo Usuário...............................................59

4.4.2. Teste com Cenário .....................................................................................6 60

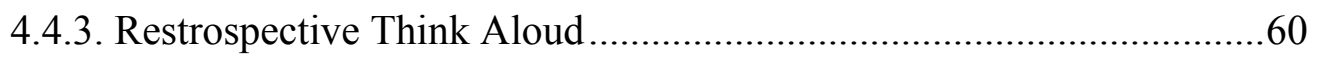

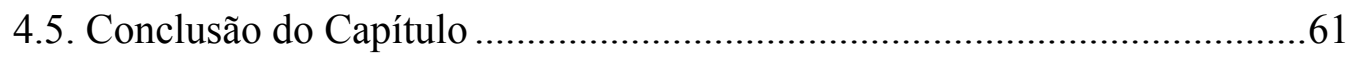

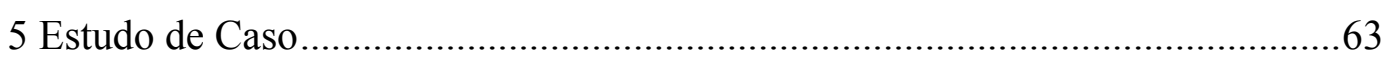

5.1. Caracterização do Estudo de Caso ..............................................................63

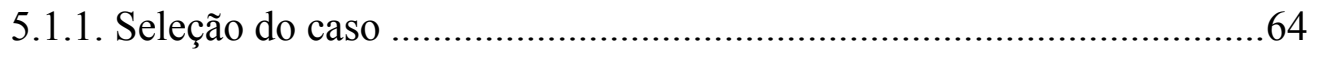

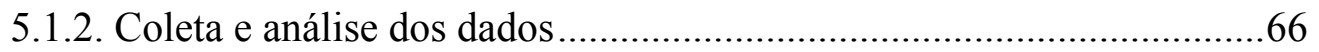

5.2. Desenvolvimento do Estudo de Caso .............................................................68

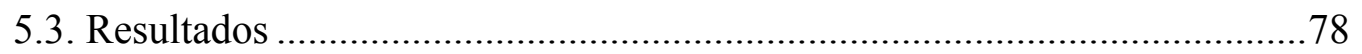


5.3.1. Exame de questões de projeto relacionadas à comunicabilidade da

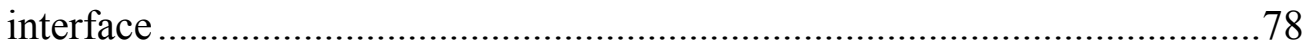

5.3.2. Emprego correto de conceitos de Engenharia Semiótica .....................83

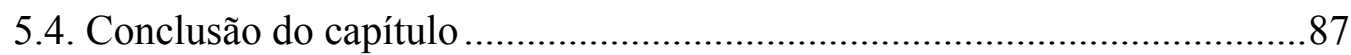

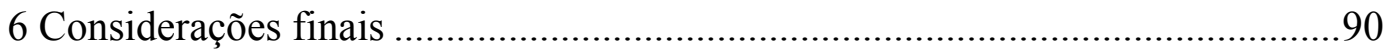

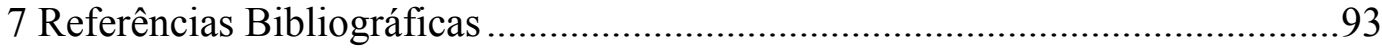

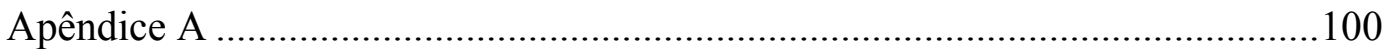

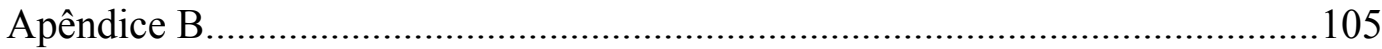

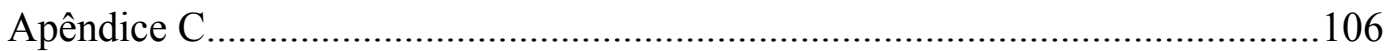

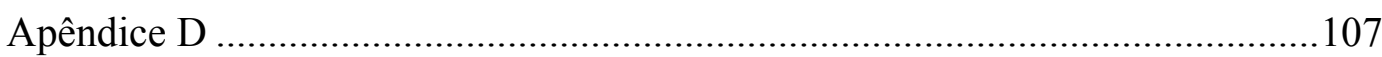




\section{Lista de Figuras}

Figura 1: (a) Soap-buble user interface (Döring et al., 2010) -

(b) Shape-shifting lamp (Yao et al., 2013) -

(c) Illuminating Clay (Ishii et al., 2004) -

(d) e (e) Workshop com estudantes (Brade et al., 2013) -

(f) Interação com simulação da luz do dia (Nasman e Cutler, 2013). 13

Figura 2: Exemplos de diferentes significações para um mesmo objeto................15

Figura 3: Resultados da seleção de artigos. .......................................................21

Figura 4: Número de artigos selecionados por ano de publicação.........................22

Figura 5: Ciclo de Vida da Prototipação...............................................................25

Figura 6: Relação Triádica de Peirce........................................................................34

Figura 7: Semiose ilimitada (Prates e Barbosa, 2007, p.270)...............................35

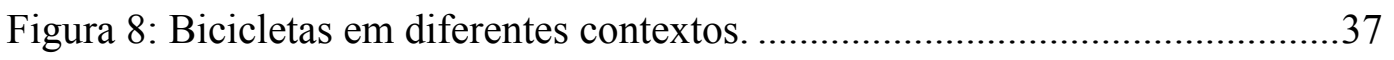

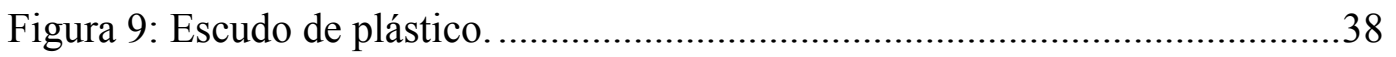

Figura 10: Teste de usabilidade do Paper Prototyping (Snyder, 2003). ................43

Figura 11: Exemplo de esboço utilizando o DENIM (Lin, Thomsen E Landay, 2002)

Figura 12: As três etapas da Prototipação Colaborativa de Tangíveis Baseada na

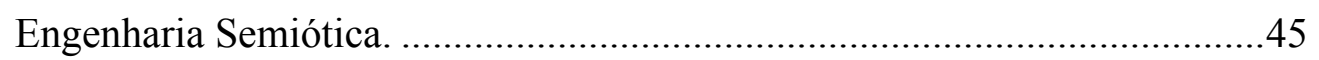

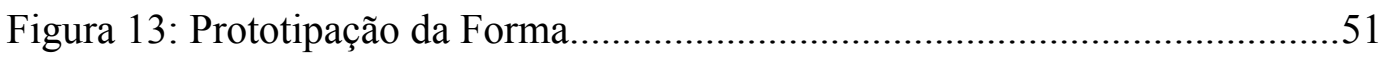

Figura 14: Exemplos de Prototipação da Forma....................................................52

Figura 15: Prototipação do Comportamento...........................................................55

Figura 16: Exemplo de circuito e programação implementados com a

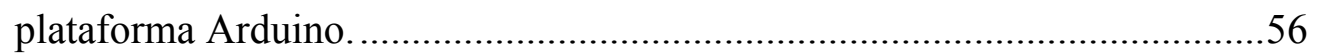

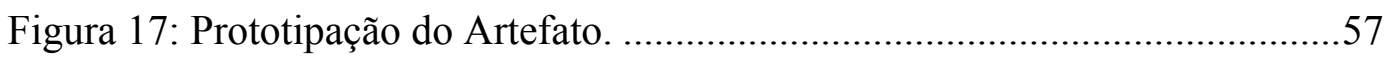

Figura 18: Exemplos de construção do Artefato...................................................58

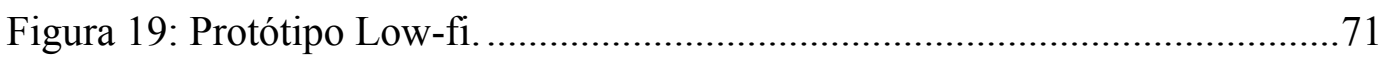

Figura 20: Prototipação do Artefato. .................................................................... 73

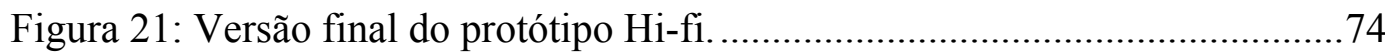




\section{Lista de Tabelas}

Tabela 1: Planejamento da Revisão. 19

Tabela 2: Número de Publicações Relacionadas a projeto e avaliação de TUIs. ..23

Tabela 3: Métodos, modelos, técnicas e abordagens para projeto de TUIs. .23

Tabela 4: Métodos de avaliação utilizados e aspectos relacionados ao uso de TUIs. .27

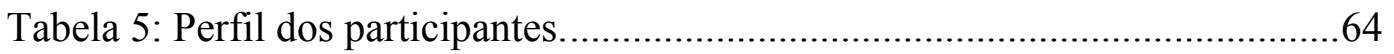

Tabela 6: Parâmetros de análise...........................................................................66

Tabela 7: Testes com usuários durante a etapa de Prototipação do Artefato..........76

Tabela 8: Resultados da observação direta relativos ao exame de questões de projeto relacionadas à comunicabilidade da interface.

Tabela 9: Resultados da análise de documentos relativos ao exame de questões de projeto relacionadas à comunicabilidade da interface.

Tabela 10: Resultados da entrevista relativos ao exame de questões de projeto relacionadas à comunicabilidade da interface.

Tabela 11: Resultados individuais relativos ao exame de questões de projeto relacionadas à comunicabilidade da interface.

Tabela 12: Resultados da observação direta relativos ao emprego correto de conceitos de Engenharia Semiótica na etapa de Prototipação da Forma

Tabela 13: Resultados da observação direta relativos ao emprego correto de conceitos de Engenharia Semiótica na etapa de Prototipação do Artefato....85

Tabela 14: Resultados da análise de documentos relativos ao emprego correto de conceitos de Engenharia Semiótica.

Tabela 15: Resultados da entrevista relativos ao emprego correto de conceitos de Engenharia Semiótica.

Tabela 16: Resultados individuais relativos ao emprego correto de conceitos de Engenharia Semiótica.

Tabela 17: Resultados individuais para cada parâmetro de análise. .88

Tabela 18: Artigos selecionados na revisão sistemática. 100

Tabela 19: Benefícios percebidos pelos participantes. 107 


\section{Introdução}

Nas décadas de 80 e 90, as interfaces de usuário evoluíram de interpretadores de comandos - paradigma "remember and type" - com interação via teclado em terminais de computador, para interfaces gráficas de usuários paradigma "see, point and click" - nas quais uma metáfora do mundo real é representada por meio de elementos gráficos para apoiar o uso dos sistemas. Recentemente, com a incorporação de recursos computacionais aos elementos físicos, a computação está presente nos elementos do ambiente físico. Casas, móveis, e objetos do dia-a-dia, isto é, o ambiente que nos cerca, são as novas interfaces com as quais as pessoas interagem para colaborar e se informar, incorporando a visão de Mark Weiser, que advoga que as tecnologias mais profundas são as que desaparecem e "weave themselves into the fabric of everyday life until they are indistinguishable from it" (Weiser, 1991). Essas novas interfaces implicam em um novo paradigma de interação, ainda pouco conhecido e explorado.

Milênios de evolução resultaram no desenvolvimento de habilidades sofisticadas que seres humanos possuem para sentir e manipular seu ambiente físico. Segundo Ishii (2008), estas habilidades são ainda pouco exploradas na interação com o mundo digital, pois esta é predominantemente por meio de interfaces gráficas (GUIs), que são adaptáveis o suficiente para emular graficamente uma variedade de mídias, mas não tiram vantagem de nossas habilidades em manipular objetos físicos. Diferentemente de GUIs, as interfaces tangíveis (Tangible User Interfaces - TUIs ${ }^{1}$ ) empregam formas físicas com o intuito de tirar vantagem das habilidades que os usuários têm de manipular objetos. Interfaces tangíveis "dão forma física à informação digital [...] tornando a informação digital diretamente manipulável e perceptível através de nossos

\footnotetext{
${ }^{1}$ Termo cunhado por Ishii e Ullmer (1997).
} 
sentidos por meio de sua incorporação física" (Ishii, 2008), o que possibilita "combinar os benefícios dos modelos físico e digital na mesma representação" (Ratti et al., 2004).

Interfaces tangíveis são usadas em diferentes domínios, como solução de problemas, entretenimento e aprendizagem, podendo ser combinadas com GUIs, superfícies interativas, realidade virtual e realidade aumentada, criando formas diversas de interação. Interagir com uma interface tangível envolve o uso de sentidos, como o tato (e.g. toque, sensação de movimento, pressão, temperatura, força mecânica) e olfato (odores), e o corpo de maneiras pouco exploradas em outros tipos de interface, como ilustram os exemplos da Figura 1. Diferentemente dos computadores desktop e outros dispositivos computacionais atualmente utilizados, a interação com o usuário (ou com o ambiente) pode acarretar alterações relativas à sua forma (formato, cor, luminosidade, articulações, textura, temperatura, etc.). TUIs podem ainda ser dotadas com a capacidade de sentir o modo como o usuário interage, por exemplo, como seguram ou manipulam partes ou toda a interface, e ajustar a forma de interação (Schmid, Rümelin e Richter, 2013).

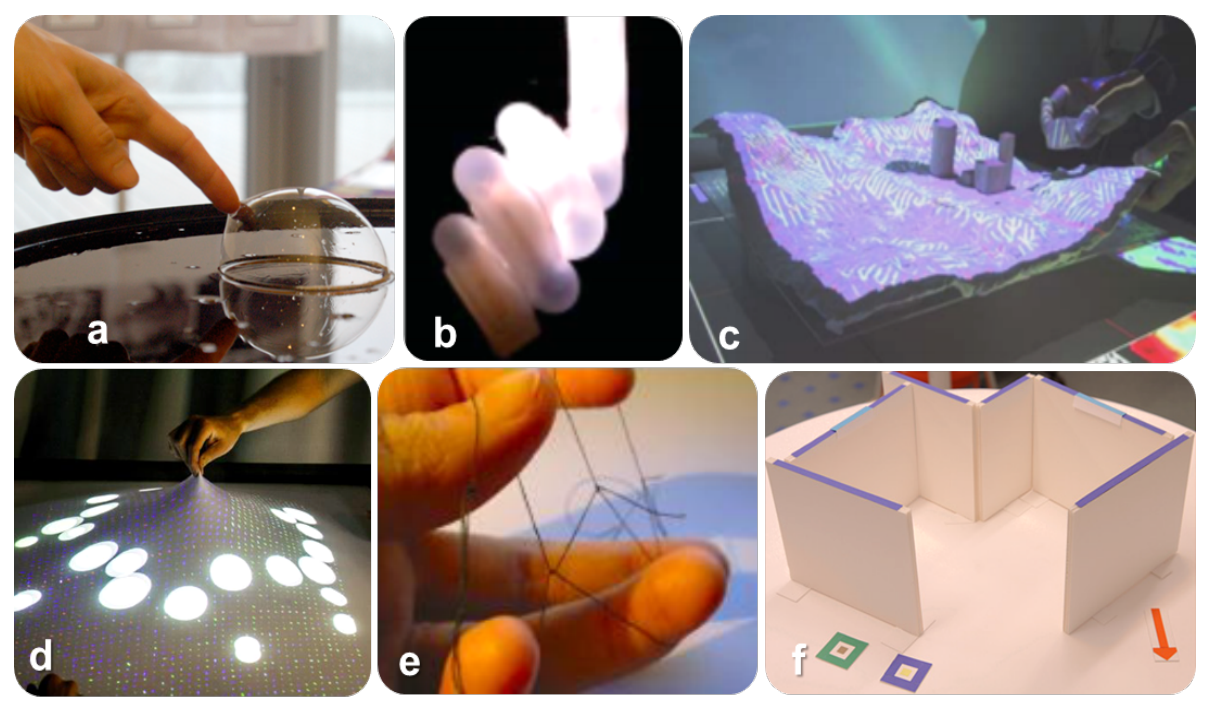

Figura 1: (a) Soap-buble user interface (Döring et al., 2010) - (b) Shapeshifting lamp (Yao et al., 2013) - (c) Illuminating Clay (Ishii et al., 2004) - (d) e (e) Workshop com estudantes (Brade et al., 2013) - (f) Interação com simulação da luz do dia (Nasman e Cutler, 2013).

Desenvolver interfaces tangíveis requer combinar o trabalho voltado para o concreto (forma) com a abstração característica do desenvolvimento de software (comportamento). O design de interfaces tangíveis não é necessariamente gráfico, 
envolvendo também aspectos físicos, como forma e materiais (Figura 1). Características como formato, flexibilidade e textura compõem novas dimensões para projeto de interfaces.

Os aspectos físicos envolvidos na interação com este tipo de interface é a principal característica que a diferencia das demais. É também um dos maiores desafios para o projeto de tangíveis, uma vez que a interface é um objeto físico com as funções advindas de sua forma, mas também possui um comportamento incluído intencionalmente pelo designer, que é agregado ao tangível por meio de software. O comportamento corresponde às intenções do designer e pode até mesmo não envolver a função inicialmente associada à forma do tangível. Pode, por exemplo, ter como objetivo tornar o tangível mais divertido, surpreendente ou até mesmo subverter as expectativas do usuário. Um travesseiro que ri, uma luminária que faz elogios ou uma espada que faz cócegas são alguns exemplos de possíveis tangíveis que, pela inclusão de comportamento (software), agregam ou modificam funcionalidades de um objeto, deste modo alterando a forma de interação do usuário com a interface. Nestes casos, uma abordagem exclusivamente funcional não fornece uma base suficientemente abrangente para o projeto de TUIs.

Desde o início de nossas vidas, boa parte de nossa interação com o mundo que nos cerca envolve a interação com objetos (artefatos materiais ${ }^{2}$ ). De maneira geral, artefatos materiais visam primariamente cumprir uma função prática ou estética, mas “não há artefato que não esteja impregnado de significado" (Danesi e Perron, 1999). Nosso talento para perceber os aspectos funcionais de um artefato se origina de nossa habilidade natural de perceber affordances ${ }^{3}$ em objetos. No entanto, esta não é nossa única capacidade com relação à percepção dos objetos. Somos capazes de fazer uso da razão para interpretar as características dos artefatos e inferir intenções e objetivos de outras pessoas (Keil et al., 2007 apud Siefkes, 2012). Nossa interação com os artefatos materiais, portanto, não se limita apenas a seu uso ou função, mas pode ocorrer em função de seu significado,

\footnotetext{
${ }^{2} \mathrm{O}$ termo artefato denota algo criado por humanos (de Souza, 2005); artefatos materiais são aqueles formados por matéria.

${ }^{3}$ O termo "affordance", criado pelo psicólogo James J. Gibson (1979), refere-se às possíveis ações disponíveis no ambiente para um ator (uma pessoa ou animal), independentemente da capacidade do ator percebê-las; suas affordances determinam como o artefato pode ser utilizado.
} 
envolvendo memórias, apego emocional, necessidades psicológicas, estilos, conotação social ou referências culturais (Siefkes, 2012). Uma cadeira como um móvel para se sentar é uma percepção baseada em sua função (affordance), por exemplo. No entanto, a visão ou utilização de uma cadeira "promove sensações, sentimentos e ideias no observador ou usuário e de significações decorrentes da percepção deste tipo de objeto no mundo" (Teixeira, Matos e Perassi, 2011) que vão além de seu uso. Os elementos visuais de um artefato, como materiais, cores e símbolos gráficos, são capazes de configurar a significação do objeto, como ilustram os exemplos da Figura 2. Cada uma destas cadeiras, mesmo tendo a mesma função, por sua forma e elementos visuais geram diferentes impressões relativas ao contexto de uso (casa, trabalho, ar livre,...) e a seu usuário (criança, executivo, vovó,...) e representam diferentes conceitos, que diferem também em função das experiências de seu observador ou usuário, sua classe social, sexo, etnia, etc.

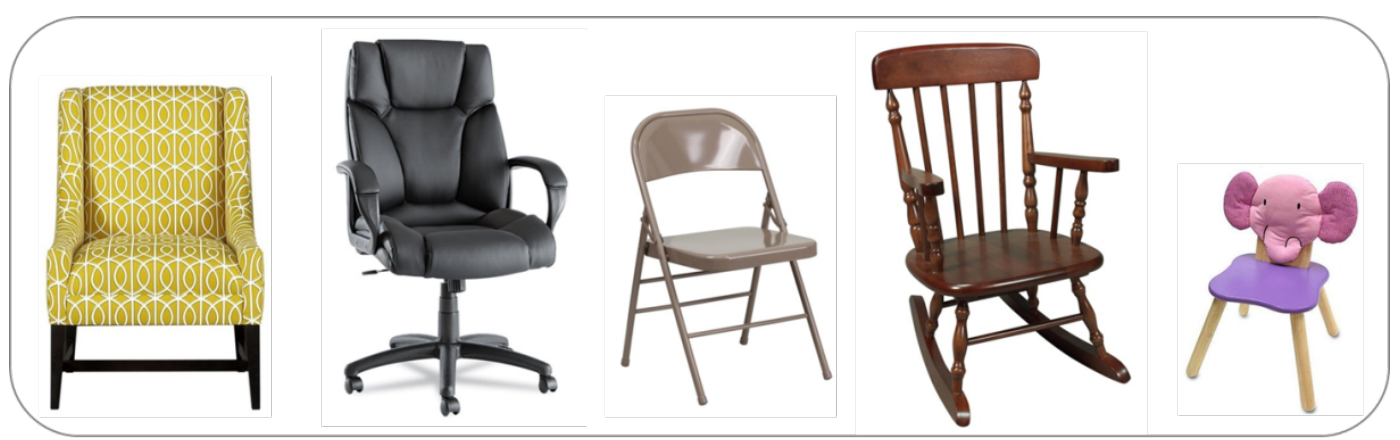

Figura 2: Exemplos de diferentes significações para um mesmo objeto.

Tendo isto em vista, é importante adotar uma abordagem de projeto para tangíveis que possibilite a percepção da interface como um artefato material e, portanto, algo físico, construído intencionalmente e impregnado de significados. Neste sentido, as abordagens que têm como base teórica a semiótica, disciplina que estuda os processos de significação e comunicação em geral, mostram-se apropriadas ao projeto de TUIs. A semiótica, por ser centrada na comunicação, considera o processo de significação do artefato tanto do ponto de vista do usuário (receptor da mensagem/interpretação) como do designer (emissor da mensagem/intenção). Esta significação envolve também os aspectos materiais do artefato, endereçando também a questão da fisicalidade deste tipo de interface.

Dentre as abordagens envolvendo semiótica, destaca-se a Engenharia Semiótica (de Souza et al., 2001; de Souza, 2005), uma teoria explicativa de IHC, 
na qual a interação humano-computador é, de fato, uma comunicação humana mediada por computador. Do ponto de vista da Engenharia Semiótica, o significado da interface "está intrinsicamente associado tanto à intenção de seu criador como à interpretação de seu usuário de como, quando e onde pode ser utilizada" (de Souza, 2005). Através da interface, de diversas maneiras, direta ou indiretamente, os designers comunicam aos usuários como podem ou devem interagir com o artefato. Para a Engenharia Semiótica, "o projeto de interface para a interação humano-computador é vista como uma engenharia de comunicação" (Bim, 2009).

Este trabalho propõe um método denominado Prototipação Colaborativa de Tangíveis Baseada na Engenharia Semiótica, detalhado no Capítulo 4, que combina as abordagens de prototipação e da Engenharia Semiótica no projeto de interfaces tangíveis. Ao combinar estas abordagens, o método agrega os benefícios da experimentação continuada de forma estruturada proporcionada pela prototipação com as vantagens do foco na comunicabilidade da Engenharia Semiótica no projeto de tangíveis, abordada no Capítulo 3. O método proposto incorpora a um método de prototipação colaborativa pré-existente a perspectiva da Engenharia Semiótica, adaptando-o de modo a promover a aplicação de conceitos de Engenharia Semiótica ao longo do processo de prototipação sem que para isto os designers necessitem ter conhecimento prévio destes conceitos. Um estudo de caso é conduzido a fim de investigar se o método proposto efetivamente contribui para incorporação da perspectiva da Engenharia Semiótica ao projeto de interfaces tangíveis.

\subsection{Questão, objetivo e método de pesquisa}

O desenvolvimento de interfaces tangíveis e suas novas formas de uso são assuntos ainda pouco conhecidos e explorados. É preciso, portanto, avançar no estudo da interação com interfaces tangíveis sob a perspectiva de IHC, o que envolve a questão do projeto deste tipo de interfaces. Tendo isto em vista, a questão inicial pesquisa que motivou este estudo foi: "Como apoiar os designers no projeto de interfaces tangíveis?". Mais especificamente, este trabalho propõe a Engenharia Semiótica como base teórica para esta questão, o que resulta na seguinte questão de pesquisa: 
Como apoiar os designers no projeto de interfaces tangíveis adotando a abordagem centrada na comunicação proposta pela Engenharia Semiótica?

Diante desta questão, este trabalho pretende contribuir oferecendo aos designers um método fundamentado na Engenharia Semiótica que apoie o projeto de interfaces tangíveis. $\mathrm{O}$ método, denominado Prototipação Colaborativa de Tangíveis Baseada na Engenharia Semiótica, combina as abordagens de prototipação e da Engenharia Semiótica no projeto de interfaces tangíveis. Seu objetivo é incorporar a um método de prototipação de interfaces tangíveis, previamente existente, a perspectiva da Engenharia Semiótica, ${ }^{4}$ cujo foco é a comunicabilidade da interface, sem que os designers necessitem ter conhecimento prévio de conceitos de Engenharia Semiótica.

Para que o método proposto seja bem sucedido, é necessário que os designers efetivamente adotem uma perspectiva centrada na comunicação designer-usuário mediada pela interface no projeto do tangível. Por este motivo, define-se como objetivo geral desta pesquisa:

Investigar se o método proposto contribui para a incorporação da perspectiva da Engenharia Semiótica ao projeto de interfaces tangíveis.

A efetiva adoção desta perspectiva envolve a aplicação dos conceitos de Engenharia Semiótica, em alguns casos desconhecidos pelos designers. Considerando esta necessidade, o método foi estruturado de modo a promover a aquisição $^{5}$ e aplicação de conceitos $^{6}$ de Engenharia Semiótica no projeto da interface ao longo do processo de prototipação, como detalhado no Capítulo 4. Uma vez que a aquisição e aplicação de conceitos de Engenharia Semiótica ao longo do processo de prototipação é fator crítico de sucesso na aplicação deste método, define-se como objetivos específicos desta pesquisa:

\section{- Investigar se o método proposto contribui para a aquisição de conceitos}

de Engenharia Semiótica no projeto de interfaces tangíveis; e

$4 \mathrm{Na}$ perspectiva da Engenharia Semiótica, a interação humano-computador é uma comunicação humana (designer-usuário) mediada por computador (de Souza, 2005).

${ }^{5}$ No escopo deste estudo, aquisição de conceitos refere-se à ação de compreender e assimilar (reter) um conhecimento.

${ }^{6}$ No escopo deste estudo, conceito (definição, concepção, caracterização) refere-se à formulação de uma ideia por meio de palavras. 
- Investigar se o método proposto contribui para a aplicação de conceitos de Engenharia Semiótica no projeto de interfaces tangíveis.

Neste estudo, foi conduzida uma pesquisa qualitativa que utiliza o método de pesquisa de Estudo de Casos. O estudo de caso desenvolvido foi baseado na aplicação do método proposto no projeto de uma interface tangível com uma equipe de designers com pouco ou nenhum conhecimento inicial relativo a conceitos de Engenharia Semiótica. A caracterização, desenvolvimento e os resultados deste estudo de caso encontram-se detalhados no Capítulo 5.

Vale ressaltar que não é escopo deste trabalho investigar outras questões referentes à aplicação deste método, nem investigar questões relacionadas à comunicabilidade de interfaces tangíveis. Seu ponto focal é a aplicação de conceitos de Engenharia Semiótica no projeto de tangíveis com a utilização do método proposto.

\subsection{Organização da tese}

Este capítulo teve por objetivo da uma visão geral acerca de questões pertinentes ao desenvolvimento deste trabalho, enfocando os principais conceitos e desafios envolvidos no projeto de interfaces tangíveis. Neste capítulo foi também apresentado o escopo, objetivos e métodos de pesquisa que nortearam o desenvolvimento deste trabalho.

O Capítulo 2 apresenta os resultados da revisão de literatura relacionada ao projeto de interfaces tangíveis (TUIs). O Capítulo 3 enfoca a Engenharia Semiótica, apresentando de forma sucinta seus principais conceitos e métodos. No Capítulo 4, é descrito em detalhes o método aqui proposto. O estudo de caso é apresentado no Capítulo 5 e seus resultados discutidos no Capítulo 6, que também apresenta sugestões para trabalhos futuros. 


\section{Revisão de Literatura}

Nesta seção, é apresentada a revisão de literatura relacionada ao tema deste trabalho: projeto de interfaces tangíveis (TUIs). Nesta revisão, a avaliação de TUIs será considerada como um tópico específico, a fim de incluir os estudos relativos à avaliação deste tipo de interface, mesmo quando ocorre fora do contexto de seu projeto. Os métodos da Engenharia Semiótica não serão incluídos nesta revisão, uma vez que são descritos no Capítulo 3.

A revisão aqui apresentada trata-se de uma revisão sistemática. Esta é "uma revisão planejada para responder a uma pergunta específica e que utiliza métodos explícitos e sistemáticos para identificar, selecionar e avaliar criticamente os estudos, e para coletar e analisar os dados destes estudos incluídos na revisão" (Castro, 2001). Na literatura, são encontradas diferentes descrições de como deve ser realizada uma Revisão Sistemática. Neste trabalho, são adotadas as três fases propostas por Kitchenham e Charters (2010):

a) Planejamento da revisão.

b) Condução da revisão; e

c) Relatório de revisão.

\subsection{Planejamento da Revisão}

O planejamento da revisão inclui a definição das questões de pesquisa, a estratégia de pesquisa, critérios para determinar a validade dos estudos selecionados e procedimentos para seleção dos estudos, apresentados na Tabela 1.

Tabela 1: Planejamento da Revisão.

\begin{tabular}{|l|c|}
\hline \multicolumn{1}{|c|}{ Item } & \multicolumn{1}{c|}{ Descrição } \\
\hline $\begin{array}{l}\text { Questões de } \\
\text { pesquisa }\end{array}$ & $\begin{array}{c}\text { SQ1: Que métodos, modelos, técnicas e abordagens são usados no } \\
\text { projeto e avaliação de TUIs? }\end{array}$ \\
& $\begin{array}{c}\text { SQ2: Dentre estes métodos, modelos, técnicas e abordagens, quais } \\
\text { envolvem semiótica? }\end{array}$ \\
\hline
\end{tabular}




\begin{tabular}{|c|c|}
\hline Item & Descrição \\
\hline & $\begin{array}{l}\text { Estágio 1: busca em bases de dados eletrônicas selecionadas em } \\
\text { função de sua relevância na área de informática; } \\
\text { Estágio 2: busca manual de estudos de grupos de pesquisa indicados } \\
\text { por especialista; e } \\
\text { Estágio 3: busca manual de livros indicados por especialista. }\end{array}$ \\
\hline $\begin{array}{l}\text { Critérios de } \\
\text { inclusão }\end{array}$ & $\begin{array}{l}\text { Estudos em inglês ou português, publicados no período de } 2003 \text { a } 2013 \\
\text { que contenham informações sobre métodos, modelos, técnicas e } \\
\text { abordagens usados para projeto e/ou avaliação de TUIs (questões de } \\
\text { pesquisa). }\end{array}$ \\
\hline $\begin{array}{l}\text { Critérios de } \\
\text { exclusão }\end{array}$ & $\begin{array}{l}\text { No caso de estudos que envolvam o uso de tangíveis em conjunto com } \\
\text { dispositivos móveis, tabletops, realidade aumentada ou realidade } \\
\text { virtual, estes somente serão considerados caso o projeto ou avaliação } \\
\text { da interface tangível seja o foco do estudo. }\end{array}$ \\
\hline $\begin{array}{l}\text { Procedimento } \\
\text { para seleção } \\
\text { dos estudos }\end{array}$ & $\begin{array}{l}\text { Passo 1: seleção de estudos em bases de dados eletrônicas e grupos de } \\
\text { estudo que sejam pertinentes às questões de pesquisa } \\
\text { definidas; } \\
\text { Passo 2: leitura dos títulos e resumos dos estudos selecionados no } \\
\text { passo 1; } \\
\text { Passo 3: exclusão dos estudos selecionados no passo } 1 \text { que não } \\
\text { atendam aos critérios definidos; } \\
\text { Passo 4: leitura integral dos estudos resultantes do passo 3; } \\
\text { Passo 5: exclusão dos estudos resultantes do passo } 3 \text { que não atendam } \\
\quad \text { aos critérios definidos; } \\
\text { Passo 6: coleta e registro de dados em planilha dos estudos resultantes } \\
\quad \text { do passo 5; e } \\
\text { Passo 7: tabulação e análise dos dados. }\end{array}$ \\
\hline
\end{tabular}

No caso da busca manual, o Prof. Hugo Fuks, orientador deste trabalho, atuou como especialista na indicação de grupos de pesquisa e livros. Estes são detalhados na seção a seguir.

\subsection{Condução da Revisão}

A busca de artigos foi realizada em um conjunto pré-definido nas bases eletrônicas: IEEE Xplore ${ }^{7}$, ACM Digital Library, ${ }^{8}$ ScienceDirect $^{9}$ e Web of Knowledge, ${ }^{10}$ e em sites de grupos de pesquisa reconhecidos como referência na área de TUIs - GroupLab ${ }^{11}$ ( University of Calgary) e Tangible Media Group ${ }^{12}$ (MIT). As palavras-chave utilizadas nesta pesquisa foram: "tangible user

\footnotetext{
${ }^{7} \mathrm{http}: / /$ ieeexplore.ieee.org

${ }^{8} \mathrm{http}: / / \mathrm{dl}$.acm.org

${ }^{9} \mathrm{http}: / / \mathrm{www}$. sciencedirect.com/

${ }^{10} \mathrm{http}: / /$ apps.webofknowledge.com/

${ }^{11} \mathrm{http}: / /$ grouplab.cpsc.ucalgary.ca/

${ }^{12} \mathrm{http}: / /$ tangible.media.mit.edu/
} 
interface", "wearable user interface", "design", "usability" e "semiotic", resultando na string “('tangible user interface' OR 'wearable user interface') AND ('design' OR 'usability' OR 'evaluation' OR 'semiotic')” para busca nos campos título, resumo e palavras-chave. Vale ressaltar que os termos "usability", e "evaluation" não são excludentes na busca. O termo "usability" foi incluído no intuito de incluir artigos que não mencionem o termo "evaluation", mas envolvam estudos relacionados à usabilidade, complementando assim a string de busca. $\mathrm{O}$ termo "semiotic" foi incluído especificamente para a identificação de artigos relacionados à semiótica e interfaces tangíveis na seleção inicial, independente do tipo de estudo.

As etapas de seleção e resultados são apresentados na Figura 3. O Apêndice A contém a relação dos 38 artigos selecionados.

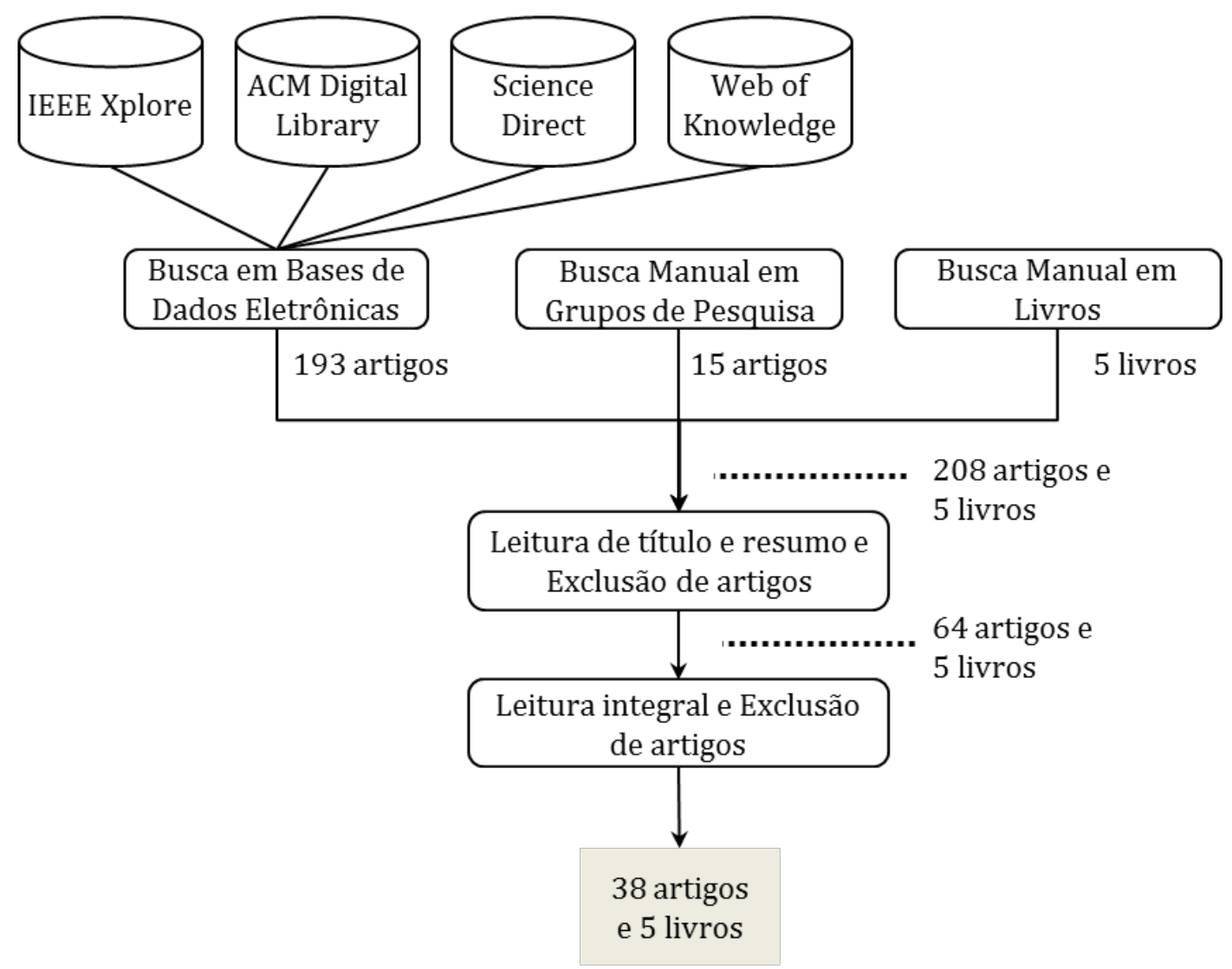

Figura 3: Resultados da seleção de artigos.

Além de artigos, foram incluídos nesta revisão os seguintes livros:

- Arnowitz, Arent e Berger, 2007 - Effective Prototyping for Software Maker;

- Bowman et al., 2004 - 3D User Interfaces: Theory and Practice; 
- Buxton, 2007 - Sketching User Experience: Getting the Design Right and the Right Design;

- Greenberg et al., 2011 - Sketching User Experiences: The Workbook; e

- Kortum, 2008 - HIC Beyond the GUI - Design for Haptic, Speech, Olfactory, and Other Nontraditional Interfaces.

\subsection{Relatório da Revisão}

Dentre os 208 artigos inicialmente selecionados, observa-se maior concentração de artigos publicados nos anos de 2009 (13\%) e 2010 (15\%), como mostra o gráfico da Figura 4. A maioria destes artigos (79\%) foi publicada em anais de conferências e os demais em periódicos. A base de dados eletrônica com maior número de publicações inicialmente selecionadas foi a Web of Knowledge (53\%), seguida da ACM Digital Library (46\%). A maioria dos artigos da seleção final foi resultante da busca na ACM Digital Library (55\%). Vale destacar que o mesmo artigo pode constar em bases distintas. Neste caso, 41 dos artigos iniciais foram encontrados em mais de uma base, mas totalizados apenas uma vez.

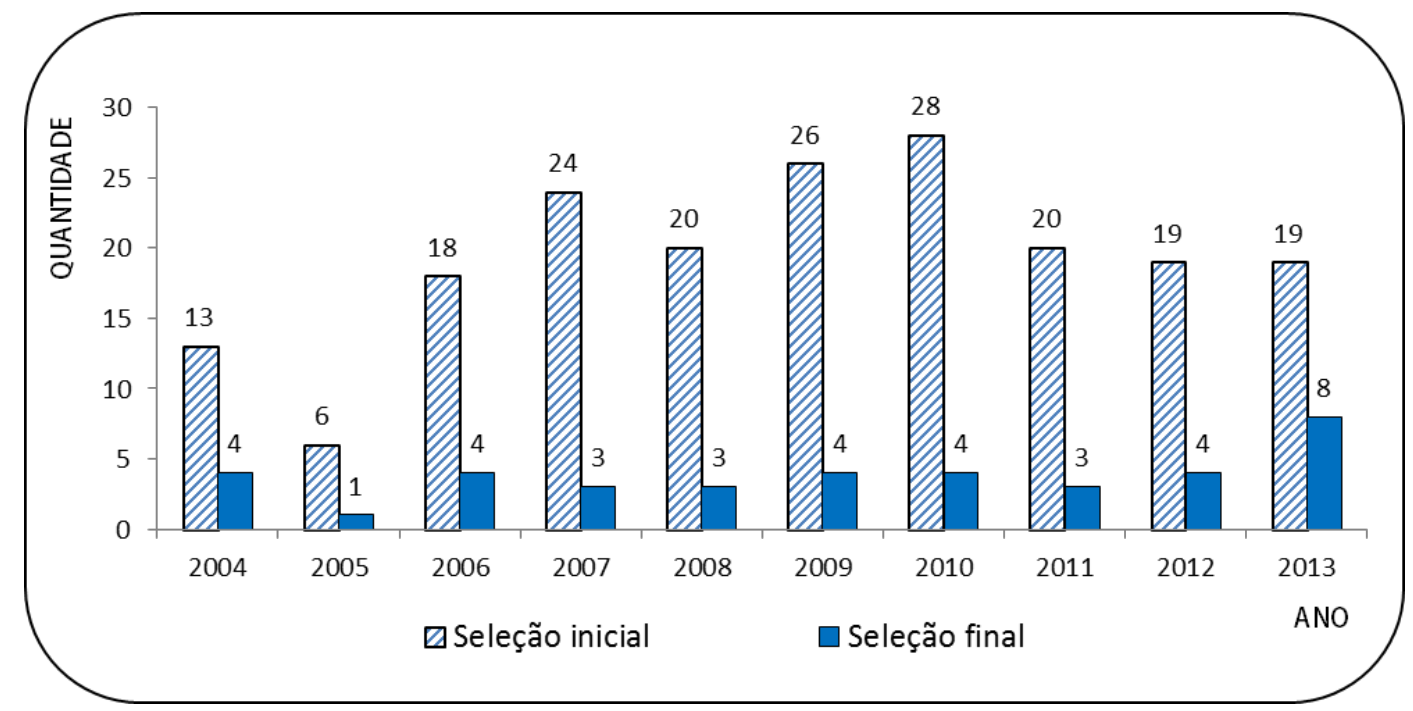

Figura 4: Número de artigos selecionados por ano de publicação.

Das publicações finais selecionadas (artigos e livros), 79\% apresentam métodos, modelos, técnicas ou abordagens para o projeto de TUIs e $60 \%$ enfocam a avaliação de TUIs, como mostram os resultados da Tabela 2. Algumas publicações trataram tanto de projeto como de avaliação, sendo consideradas na totalização em ambos os casos. Por este motivo, a soma das publicações relacionadas a projeto e a avaliação supera o número de publicações selecionadas nesta tabela. 
Tabela 2: Número de Publicações Relacionadas a projeto e avaliação de TUIs.

\begin{tabular}{|c|c|c|c|}
\hline \multirow{2}{*}{$\begin{array}{c}\text { Tipo de } \\
\text { Publicação }\end{array}$} & $\begin{array}{c}\mathbf{N}^{\mathbf{0}} \text { publicações } \\
\text { selecionadas }\end{array}$ & \multicolumn{2}{|c|}{$\mathbf{N}^{\mathbf{0}}$ de publicações relacionadas a... } \\
\cline { 3 - 4 } & 38 & projeto de TUI & avaliação de TUI \\
\hline Artigo & 05 & 28 & 24 \\
\hline Livro & 42 & $33(79 \%)$ & 01 \\
\hline Total & & 05 & $25(60 \%)$ \\
\hline
\end{tabular}

Com base nas publicações selecionadas, foram identificados diversos métodos, modelos, técnicas e abordagens utilizadas no projeto de TUIs, como mostra a Tabela 3. Estes podem ser organizados em três categorias principais:

- Prototipação; ${ }^{13}$

- Métodos, técnicas e abordagens usados na área de Design aplicados ao projeto de TUIs; e

- Teorias aplicadas, Modelos, Frameworks e Linguagens.

Tabela 3: Métodos, modelos, técnicas e abordagens para projeto de TUIs.

\begin{tabular}{|c|c|c|c|}
\hline \multicolumn{2}{|c|}{ Categoria } & Exemplos & Referências \\
\hline \multirow[t]{11}{*}{ Prototipação } & \multirow[t]{2}{*}{$\begin{array}{l}\text { Prototipação de } \\
\text { baixa fidelidade }\end{array}$} & $\begin{array}{l}\text { Prototipação Blank } \\
\text { Model }\end{array}$ & $\begin{array}{l}\text { Arnowitz, Arent e Berger, } \\
2007\end{array}$ \\
\hline & & Theatrical Sketches & Buxton, 2007 \\
\hline & \multirow[t]{6}{*}{$\begin{array}{l}\text { Prototipação com } \\
\text { toolkits }\end{array}$} & Phidget & $\begin{array}{l}\text { Greenberg e Fitchet, } 2001 \\
\text { apud Döring et al., } 2010\end{array}$ \\
\hline & & Sketch-a-TUI & Wiethoff et al., 2012 \\
\hline & & Paperbox & Wiethoff et al., 2013 \\
\hline & & Surflex & $\begin{array}{l}\text { Coelho et al., } 2008 \text { apud } \\
\text { Mendes et al., } 2012\end{array}$ \\
\hline & & DisplayObjects & $\begin{array}{l}\text { Akaoka, Ginn e Vertegaal, } \\
2010 \text { apud Döring et al., } \\
2010\end{array}$ \\
\hline & & WUI-Toolkit & Witt, Nicolai e Kenn, 2006 \\
\hline & \multirow{3}{*}{$\begin{array}{l}\text { Prototipação de } \\
\text { alta fidelidade }\end{array}$} & SoloFind & Wiethoff e Broll, 2011 \\
\hline & & ColorTable & $\begin{array}{l}\text { Maquil, Psik e Wagner, } \\
2008\end{array}$ \\
\hline & & Rope Revolution & Yao et al., 2011 \\
\hline \multirow[t]{2}{*}{$\begin{array}{l}\text { Métodos, } \\
\text { técnicas e } \\
\text { abordagens da } \\
\text { área de Design }\end{array}$} & \multirow[t]{2}{*}{ Sketching } & Sketch & $\begin{array}{l}\text { Greenberg et al., } 2011 \\
\text { Chang et al., } 2007 \\
\text { Buxton, } 2007\end{array}$ \\
\hline & & Storyboard & Greenberg et al., 2011 \\
\hline
\end{tabular}

${ }^{13}$ Por ser uma abordagem também utilizada na área de computação, a prototipação não é considerada nesta revisão como uma abordagem específica da área de Design. 


\begin{tabular}{|c|c|c|c|}
\hline \multicolumn{2}{|l|}{ Categoria } & \multirow{2}{*}{$\begin{array}{c}\text { Exemplos } \\
\text { Animação ou vídeo }\end{array}$} & \multirow{2}{*}{$\begin{array}{l}\text { Referências } \\
\text { Greenberg et al., } 2011 \\
\text { Bonanni e Ishii, } 2009 \\
\end{array}$} \\
\hline & & & \\
\hline & $\begin{array}{l}\text { Design Centrado } \\
\text { no usuário }\end{array}$ & Etnografia & $\begin{array}{l}\text { Banga e Timpkaa, } 2007 \\
\text { Feltham, } 2008\end{array}$ \\
\hline & Design centrado & Soap Bubble & Döring, 2012 \\
\hline & & Illumination Clay & Ishii et al., 2004 \\
\hline & & SandScape & Ishii et al., 2004 \\
\hline \multirow{7}{*}{\multicolumn{2}{|c|}{$\begin{array}{l}\text { Teorias, Modelos, } \\
\text { Framewoks e Linguagens }\end{array}$}} & $\begin{array}{l}\text { Aplicação de conceitos } \\
\text { de semiótica }\end{array}$ & $\begin{array}{l}\text { Banga e Timpkaa, } 2007 \\
\text { Hsieh et al., } 2010\end{array}$ \\
\hline & & Radio Play Method & Pirhonen e Murphy, 2008 \\
\hline & & $\begin{array}{l}\text { Framework Interaction } \\
\text { Frogger }\end{array}$ & $\begin{array}{l}\text { Blackwell, } 2003 \text { apud Edge } \\
\text { Blackwell, } 2006\end{array}$ \\
\hline & & $\begin{array}{l}\text { The Cognitive } \\
\text { dimensions (CDs) } \\
\text { framework }\end{array}$ & Shaer e Jacob, 2009 \\
\hline & & $\begin{array}{l}\text { User Interface } \\
\text { Description Language } \\
\text { for TUIs (TUIML) }\end{array}$ & Fjeld, Morf e Krueger, 2004 \\
\hline & & Activity Theory & $\begin{array}{l}\text { Feijs, Peters e Eggen, } 2004 \\
\text { apud Jingyan, Yan } \\
\text { Huiwen, } 2009\end{array}$ \\
\hline & & $\begin{array}{l}\text { Model-Control- } \\
\text { Representation } \\
(\mathrm{MCRpd})\end{array}$ & $\begin{array}{l}\text { Ullmer e Ishii, } 2001 \text { apud } \\
\text { Feltham, } 2008\end{array}$ \\
\hline
\end{tabular}

O uso de métodos, técnicas e abordagens empregados na área de Design (Tabela 3) para o projeto de TUIs é frequente, em especial o uso de técnicas de Sketching (construção de esboços). Buxton (2007, p.139) diferencia este tipo de técnica da prototipação:

"Sketches (esboços) e protótipos são ambos instanciações de conceitos de design. No entanto, servem a diferentes propósitos, e, portanto, se concentram em diferentes estágios do processo de design. Sketches dominam os estágios de ideação iniciais, enquanto os protótipos se concentram mais nos estágios mais nas fases posteriores $[\ldots]$ ”. ${ }^{14}$

Dentre as abordagens estudadas, a prototipação é a mais utilizada para o projeto de TUIs. Diferentes métodos e técnicas são utilizados, resultando em protótipos de baixa ou alta fidelidade. Os protótipos de alta fidelidade apresentados nos artigos e livros, seguem as etapas definidas no Ciclo de Vida da Prototipação (Figura 5), enquanto os protótipos de baixa fidelidade são resultantes

\footnotetext{
${ }^{14}$ Tradução desta autora de trecho de texto original em língua inglesa do autor.
} 
da aplicação de métodos específicos, como Prototipação Blank Model (Arnowitz, Arent e Berger, 2007) e Theatrical Sketches (Buxton, 2007).

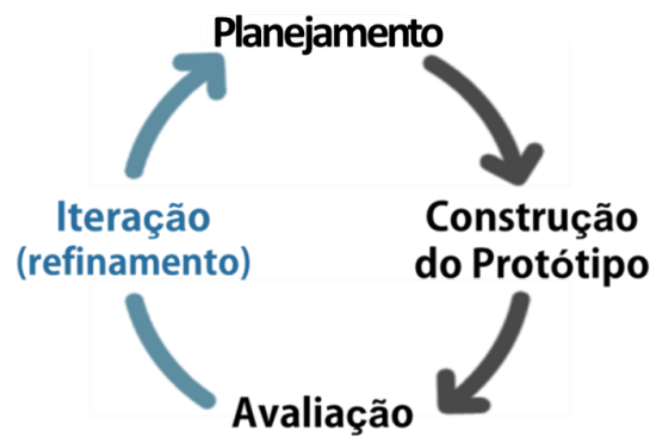

Figura 5: Ciclo de Vida da Prototipação.

O uso de toolkits para prototipação é motivado pela necessidade de se criar ferramentas para a construção de tangíveis que possibilitem a experimentação rápida com a forma da interface, como explica Wiethoff (2013): “enquanto ferramentas de prototipação estão prontamente disponíveis para GUIs, estas são raras no caso de interação com tangíveis [...] poucas ferramentas estão disponíveis para uma investigação detalhada de fatores relacionados à forma" ${ }^{\text {" }}$. Um exemplo deste tipo de toolkit é o Paperbox Toolkit, desenvolvido pelo GroupLab (Wiethoff et al., 2013). O Paperbox Toolkit é composto por objetos feitos de cartolina branca, com diferentes formas (cubos, cones, triângulos, etc.) e tamanhos. Os protótipos são construídos usando fita crepe para compor formas mais complexas e uma caneta com tinta condutiva de modo a fazer com que o objeto seja reconhecido por qualquer tela de toque capacitivo. Os protótipos resultantes do uso deste toolkit funcionam em conjunto com telas, e são feitos com material pouco resistente. Outros exemplos deste tipo de toolkit são o Surflex (Coelho et al., 2008, apud Mendes et al., 2012), e o DisplayObjects (Akaoka, Ginn e Vertegaal, 2010, apud Döring et al., 2010), como se observa na Tabela 3. No entanto, nota-se que este tipo de solução não apresenta flexibilidade na construção da forma, uma vez que as configurações resultantes são limitadas pelas combinações possibilitadas pelas unidades básicas utilizadas para a construção do tangível.

\footnotetext{
${ }^{15}$ Tradução desta autora de trecho de texto original do autor em língua inglesa.
} 
Poucos artigos enfocam a aplicação de teoria ou a proposta de modelos, linguagens e frameworks para o projeto de TUIs. Estes artigos destacam algumas questões que necessitam ser abordadas neste contexto, dentre elas: a integração do uso dos sentidos humanos no desenvolvimento da interface, a adaptação de objetos físicos existentes para o uso como componentes de uma TUI e a incorporação ao design das qualidades ou características inerentes aos objetos que possibilitam a um indivíduo realizar uma determinada ação (affordances).

Dentre os artigos selecionados, três deles contêm menção direta a semiótica no contexto de projeto de interface tangível (Banga e Timpkaa, 2007; Pirhonen e Murphy, 2008; Hsieh et al., 2010). Hsieh et al. (2010) e Banga e Timpkaa (2007) empregam conceitos de semiótica no projeto de interface. Pirhonen e Murphy (2008) propõem um método de projeto que aplica conceitos de semiótica.

Hsieh et al. (2010) apresenta a aplicação Yongzheng Emperor's Interactive Tabletop, que combina o uso de tangíveis com tabletop e mundos virtuais. A semiótica é utilizada como princípio de design e enfoca a criação de elementos físicos visando facilitar a compreensão de conceitos abstratos por meio de objetos concretos. Partindo de ilustrações do imperador Yongzheng, foram criados diferentes tangíveis com a imagem do imperador, cujos figurinos foram desenvolvidos para “interpretar sua vida na corte” (Hsieh et al.,2010).

Banga e Timpkaa (2007) apresentam um estudo sobre o uso de interfaces tangíveis um em sistema híbrido para apoio à execução de tarefas colaborativas envolvendo equipes clínicas co-localizadas. Segundo estes autores, estas interfaces foram projetadas aproveitando-se o "valor semiótico dos objetos físicos" utilizados nas tarefas diárias pelas equipes. O processo de identificação da "semiótica dos objetos físicos" utilizados na sala de emergência (pastas, formulários, caneta,...) resulta em um conjunto de padrões de comunicação que é utilizado como um framework no projeto da versão experimental do sistema.

No método Radio-Play proposto por Pirhonen e Murphy (2008), "os 'building blocks' para a abordagem adotada no método são: o design centrado no usuário, a criatividade no trabalho em grupo e a perspectiva semiótica no design de interface". Neste método, o projeto se baseia no uso de um tipo de cenário, denominado Rich Use Cenario, que tem por objetivo de incentivar a criatividade do grupo. No Radio-Play, "usuário e contexto são ambos compreendidos como 
semióticos, ou seja, são construtores de significado em vez de conceitos realistas"16 (Pirhonen e Murphy, 2008, p.333).

Para a análise dos métodos, modelos, técnicas e abordagens de avaliação de TUIs, foram consideradas as classificações de métodos de avaliação Investigação (entrevistas, questionários, grupos de foco, etc.), Inspeção (avaliação heurística, percurso cognitivo, inspeção semiótica, etc.) e Observação (estudo de campo, teste de usabilidade, avaliação de comunicabilidade, prototipação em papel, etc.) - e dos aspectos relacionados ao uso do sistema propostas por Barbosa e da Silva (2010):

- Analisar a apropriação da tecnologia;

- Comparar ideias e alternativas de design;

- Verificar a conformidade com um padrão; e

- Identificar problemas na interação e interface.

O resultado da análise dos 24 artigos relacionados à avaliação de TUIs é apresentado na Tabela 4.

Tabela 4: Métodos de avaliação utilizados e aspectos relacionados ao uso de TUIs.

\begin{tabular}{|l|c|}
\hline \multicolumn{1}{|c|}{ Aspecto } & N. de publicações \\
\hline Analisar a apropriação da tecnologia & 6 \\
\hline Comparar ideias e alternativas de design & 9 \\
\hline Verificar a conformidade com um padrão & -- \\
\hline Identificar problemas na interação e interface & 9 \\
\hline \multicolumn{1}{|c|}{ Total } & 24 \\
\hline
\end{tabular}

Dentre os artigos selecionados, foram identificados os seguintes casos de inovações em métodos de avaliação de TUIs, brevemente descritos a seguir:

- CoDeIn - COgnitive Description and Evaluation of Interaction (Christou et al., 2012, p.189):

"[...] propomos CoDeIn, um novo sistema de notação para GOMS (Card et $a l .$, 1983), com extensão para suporte à avaliação de RBIs. ${ }^{17}$ A notação fornece ferramentas para avaliar uma tarefa com relação ao conhecimento necessário para seu desempenho. Isto é feito por meio do uso de

${ }^{16}$ Tradução desta autora de trecho de texto original dos autores em língua inglesa: “[...] both 'user' and 'context' are understood as semiotic, or meaning-making, rather than realist concepts.".

17 Reality-Based Interfaces = termo utilizado que designa interfaces que se baseiam na forma como o usuário interage com o mundo real; é considerado um conceito amplo, que engloba diferentes tipos de interfaces, como NUIs e TUIs (Jacob et al., 2008). 
diagramas de notação que possibilitam que o projetista modele a interação em uma interface RBI, dados as ações da interface e o conhecimento que o usuário necessita para desempenhar cada ação". ${ }^{18}$

- Three spatial heuristics (Sharlin et al., 2004, p.338):

"Dado que somos seres espaciais e TUIs são objetos espaciais, mapeamentos bem sucedidos explorarão o conhecimento sobre como os humanos agem em seu ambiente espacial. Encontramos este conhecimento em pesquisas prévias sobre interação humana, percepção e teoria da atividade. Isolamos deste conhecimento três heurísticas. Primeiramente, mapeamentos físico/digitais devem ser mapeamentos espaciais bem sucedidos. Isto é, a relação entre as características espaciais do objeto (TUI) e seu uso deve ser congruente e/ou bem conhecida. Em segundo, mapeamentos físico/digitais devem unificar o espaço de entrada e saída. Aqui, defendemos que as distinções puramente digitais entre espaços de entrada e saída devem ser eliminadas. Finalmente, mapeamentos físico/digitais devem possibilitar atividades de tentativa-e-erro". ${ }^{18}$

A maioria dos artigos selecionados emprega métodos e técnicas comumente utilizados na avaliação de GUIs, como teste de usabilidade, aplicação de questionários e entrevistas. Em alguns casos, foram aplicadas teorias, modelos ou frameworks já utilizados para a avaliação de GUIs, tais como The Cognitive Dimensions Framework (Edge e Blackwell, 2006), GOMS - Goals, Operators, Methods, Selection Rules - (Christou et al., 2012) e Teoria da Atividade (Fjeld, Morf e Krueger, 2004), na avaliação de TUIs. Dentre os artigos selecionados não foram identificados estudos relativos à semiótica e avaliação de TUIs.

\subsection{Conclusão do Capítulo}

Este capítulo apresentou os resultados da revisão de literatura, que visou identificar métodos, modelos, técnicas e abordagens utilizados no projeto de interfaces tangíveis. Nos estudos revisados, a prototipação foi a abordagem predominante adotada no projeto de tangíveis, mas percebe-se que não há uma proposta de um método de prototipação específica para TUIs.

Algumas questões relativas a projeto de interface são abordadas nos estudos, como o uso de novos materiais, a integração do uso dos sentidos humanos no desenvolvimento da interface, a adaptação de objetos físicos existentes para o uso como componentes de uma interface tangível. Um dos conceitos adotados em projetos de interfaces revisados (e.g. Yao et al., 2011; Sharlin et al., 2004) é o conceito de affordances de Gibson (1979). A aplicação deste conceito

\footnotetext{
${ }^{18}$ Traduções desta autora de trecho de texto original dos autores em língua inglesa.
} 
desconsidera a interação em função de seu significado, o que limita a percepção do designer à interação funcional do usuário com o tangível.

Foram selecionados três artigos envolvendo semiótica e projeto de TUI. Em dois deles, a semiótica é incorporada ao processo de design: no primeiro caso, na análise de dados coletados (Banga e Timpkaa, 2007) e, no segundo, na concepção do método (Pirhonen e Murphy, 2008). Entretanto, em nenhum destes casos os conceitos de semiótica são aplicados diretamente na concepção da interface. Somente no caso dos tangíveis que representam o imperador Yongzheng (Hsieh et al.,2010) a semiótica foi aplicada na etapa de conceituação do projeto do tangível, enfocando a questão da sua significação para o usuário. Neste projeto, a semiótica foi adotada como abordagem genérica, desconsiderando o fato de se tratar de uma interação humano-computador.

A inexistência de um método de prototipação específico para o projeto de TUIs sinaliza uma oportunidade de pesquisa que vem sendo explorada pela equipe do PUC-Rio/LES/SecondLab ao desenvolver um método de prototipação colaborativa para tangíveis (Cardador et al., 2013). Neste trabalho, propõe-se incorporar a este método a perspectiva e conceitos da Engenharia Semiótica, uma teoria explicativa de IHC, na qual o projeto de interfaces tem como foco principal a comunicação designers-usuários mediada pela interface, neste caso o tangível, como descrito no Capítulo 4. Desta forma, o método proposto visa agregar os benefícios da experimentação continuada (prototipação) e da perspectiva de uma teoria de IHC centrada na comunicação (Engenharia Semiótica). 


\title{
3
}

\section{Engenharia Semiótica}

\author{
"Não vivemos no mundo real. Vivemos no \\ mundo que percebemos."
}

Jun Rekimoto

O ser humano é uma criatura que busca significado. Desde a época das cavernas nos valemos de habilidades avançadas e sofisticadas para representar nosso mundo por meio de desenhos, sons, gestos, etc., e "esta habilidade é a razão por que, ao longo do tempo, nossa espécie se tornou regida não pelas forças da seleção natural, mas por 'força da história', ou seja, pelos significados acumulados por gerações prévias, que foram capturados e passados adiante na forma de signos" (Danesi e Perron, 1999, p.29). Nossa percepção de nós mesmos e do mundo que nos cerca depende destes signos.

A semiótica estuda os signos e seus processos de significação e comunicação (Eco, 1976) e é o alicerce da Engenharia Semiótica. Signo, de modo geral, é qualquer coisa que significa algo para alguém em uma determinada circunstância. A interação humano-computador, como qualquer outra interação humana, ocorre por meio de signos.

A Engenharia Semiótica é uma teoria explicativa de IHC (de Souza et al., 2001; de Souza, 2005) que se baseia na noção de que a interação humanocomputador é, de fato, uma comunicação humana mediada por computador. Através da interface do sistema, de diversas maneiras, direta ou indiretamente, os designers comunicam aos usuários como podem ou devem interagir com o sistema para alcançar um conjunto particular de objetivos antecipados pelos designers (de Souza, 2005). Segundo Barbosa e da Silva, (2010):

"Seu foco é a comunicação entre designers, usuários e sistema. Os processos de comunicação investigados são realizados em dois níveis distintos: a comunicação direta usuário-sistema e a metacomunicação (i.e., a comunicação sobre uma comunicação) do designer para o usuário mediada pelo sistema, através de sua interface". 
A mensagem transmitida pelo artefato é indireta, "por meio dos diversos elementos da interface" (Bim, 2009). Em tempo de interação, os usuários decodificam e interpretam gradualmente a metamensagem do designer, que comunica a visão dos designers sobre quem são os usuários, o que desejam ou precisam fazer, preferencialmente de que forma, e por quê. A metamensagem do designer para o usuário pode ser resumida no seguinte esquema geral (de Souza et al., 2010):

"Este é o meu entendimento de quem você é, do que entendi que você quer ou precisa fazer, de que maneira você prefere fazer, e por quê. Este, portanto, é o sistema que projetei pra você, e esta é a forma como você pode ou deve utilizá-lo para alcançar uma gama de objetivos que se encaixam nesta visão."

Prates e Barbosa (2007) apresentam o seguinte exemplo de metamensagem para o software Student Life - uma agenda voltada para estudantes:

"Caro estudante, eu entendo que você pode ficar sobrecarregado com suas atividades acadêmicas. Assim, estou lhe propondo uma forma de manter suas atividades e prazos organizados. Você registra as informações relativas às disciplinas e seus prazos, e o sistema lhe mostra seus horários e agendamentos do dia ou do mês. Para as disciplinas e trabalhos, você pode cadastrar seus contatos, possibilitando um acesso rápido às suas informações. Além disso, você pode solicitar que lembretes dos prazos mais importantes lhe sejam enviados com antecedência. Como você também tem uma vida social, você pode incluir aqui também seus compromissos e contatos pessoais. Este sistema foi feito principalmente para alunos cursando o sistema universitário americano e o inglês é nossa língua comum de comunicação. De todo jeito, ele pode ser útil também para alunos em outros países que entendam inglês."

Do ponto de vista da Engenharia Semiótica "uma boa interface deve conter elementos que facilitem a comunicação desta mensagem" (Bim, 2009). Portanto, a qualidade central do fenômeno de IHC para a Engenharia Semiótica é a comunicabilidade, ou seja: a capacidade de o sistema comunicar ao usuário, de forma organizada e consistente, "para que o sistema serve, a quem ele se destina, quais as vantagens de utilizá-lo, como ele funciona e quais são os princípios gerais que definem as possibilidades de interação com ele" (Prates e Barbosa, 2007). Os métodos e recursos propostos pela Engenharia Semiótica para o projeto e avaliação de interfaces focam em sua comunicabilidade, como detalha a Seção 3.1 . 


\subsection{Projeto e Avaliação de interfaces baseados na Engenharia Semiótica}

A Engenharia Semiótica foi proposta originalmente como uma abordagem para o design de linguagens de interface e, gradativamente, tornou-se uma teoria de IHC. Ao longo de sua evolução, foi definindo e articulando conceitos, construindo métodos e propondo recursos para o projeto e avaliação de interfaces.

Para apoiar o designer no projeto de interfaces, é proposta a linguagem MoLIC - Modeling Language for Interaction as Conversation - (de Paula, 2003; Silva, 2005), que possibilita a modelagem da interação humano-computador como uma conversa, projetada para apoiar os designers no projeto de interfaces. A modelagem da interação é a especificação das conversas que os usuários poderão travar com o sistema, visando servir como ferramenta epistêmica, dando suporte à reflexão do designer acerca da solução interativa sendo concebida por ele, partindo do ponto de vista de que ele tem o usuário como interlocutor em uma conversa" (Sangiorgi e Barbosa, 2010). Para usar o MoLIC, é necessário que os designers tenham um conhecimento mínimo sobre a linguagem.

Os métodos propostos pela Engenharia Semiótica para a avaliação de interfaces são: o Método de Inspeção Semiótica (MIS) e o Método de Avaliação de Comunicabilidade (MAC). Estes métodos de avaliação podem ser utilizados em conjunto, em uma triangulação metodológica, que possibilita a comparação dos resultados das aplicações dos métodos.

O MIS (de Souza et al., 2006) é um método de inspeção no qual um especialista explora e analisa a interface. Seu foco está na emissão da mensagem de metacomunicação pelo designer. Visa desconstruir, segmentar e reconstruir a mensagem de metacomunicação, procurando explicitar as estratégias de comunicação usadas pelo designer. São examinadas a consistência e coerência entre os segmentos que compõem a mensagem global do designer, e também como o ele trabalhou com redundância e distribuição de classes de signos ao longo de toda a mensagem para atingir uma comunicação eficaz e eficiente com o usuário. Este método parte da identificação dos signos contidos na interface, sua classificação e análise, e envolve, em suas etapas finais, a reconstrução da mensagem original do designer por um ou mais especialistas. 
O MAC (de Souza, 2005) dá ênfase à recepção da mensagem pelos usuários e envolve a observação da interação de usuários com a interface por um (ou mais) especialista(s). A base da análise no MAC é a identificação das rupturas de comunicação que ocorrem durante a interação por um processo denominado etiquetagem. A etiquetagem consiste em analisar a interação durante a aplicação do teste (gravada em vídeo) em busca de rupturas de comunicação, que são classificadas de acordo com uma caracterização pré-estabelecida de problemas de expressão, conteúdo e intenção (de Souza, 2005). Quanto maior a severidade e o número de rupturas, mais baixa a comunicabilidade da interface (Prates e Barbosa, 2007).

\subsection{Semiótica e Artefatos Materiais}

A Engenharia Semiótica trata do processo de construção, emissão e recepção da mensagem de metacomunicação do designer por meio de signos contidos em uma aplicação computacional (software). $\mathrm{Na}$ perspectiva da Engenharia Semiótica, uma aplicação computacional é um artefato intelectual (de Souza, 2005). De forma geral, um artefato intelectual é qualquer artefato que resulta da engenhosidade humana e um exercício intelectual. Este tipo de artefato é gerado a partir da interpretação de um designer sobre uma situação-problema e sua concepção de solução, que é apresentada em uma codificação linguística. Engenharia Semiótica motiva o designer a transmitir ao usuário, através da interface do sistema, as decisões de projeto que foram tomadas, deixando tão claro quanto possível que estas decisões são resultado da interpretação do projetista para os problemas, tarefas e situações de uso.

Interfaces tangíveis são artefatos intelectuais que combinam partes físicas e linguísticas, o que tem grande impacto em seu projeto. A materialidade do tangível viabiliza o uso de signos não possíveis no caso de um software. Além de ícones, texto e efeitos sonoros, pode-se, por exemplo, utilizar texturas, materiais, vibrações, movimentos, formas geométricas e efeitos luminosos, que de alguma forma terão impacto na comunicação designer-usuário. Esta subseção visa apresentar e discutir aspectos relativos à materialidade das interfaces tangíveis, sob o ponto de vista da semiótica.

A semiótica (do grego semeiotiké ou "a arte dos sinais") tem sua origem na Grécia e remonta a Aristóteles, mas suas bases teóricas foram lançadas entre o 
final do século XIX e o início do século XX, por dois cientistas: o filósofo e matemático americano Charles Peirce (1839-1914) e o linguista suíço Ferdinand de Saussure (1857-1913). Os estudos de Peirce e Saussure seguiram caminhos independentes. Enquanto Saussure focava na caracterização formal de linguagens naturais, Peirce focava nos processos de significação e descoberta do conhecimento (de Souza, 2013).

$\mathrm{Na}$ concepção de Saussure, o signo correlaciona uma imagem acústica (significante) e um conceito (significado). Enquanto na visão de Peirce, um signo é algo que, sob certo aspecto ou modo, representa algo para alguém, não importando de que espécie seja - verbal, abstrato, concreto, etc. Para Peirce, um signo correlaciona uma representação (representamen), um referente (objeto) e um elemento mediador (interpretante), que relaciona o objeto a seu representante na mente de alguém, como no exemplo apresentado na Figura 6.

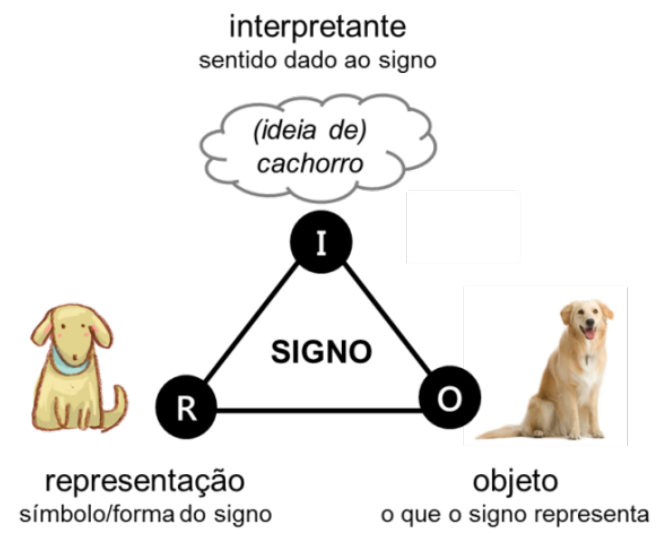

Figura 6: Relação Triádica de Peirce.

É importante notar que qualquer objeto $(\mathrm{O})$ é representado de uma maneira específica $(\mathrm{R})$ e devido a isso ele terá uma interpretação específica (I), que pode ser consciente ou não. A capacidade (inata) de produzir e compreender os signos é denominada semiose (Danesi e Perron, 1999). O processo de interpretação pode ocorrer por meio da associação de ideias, no qual "cada interpretante pode gerar novos interpretantes, e a esse processo dá-se o nome de semiose ilimitada" (Eco, 1976), como ilustra a Figura 7. 


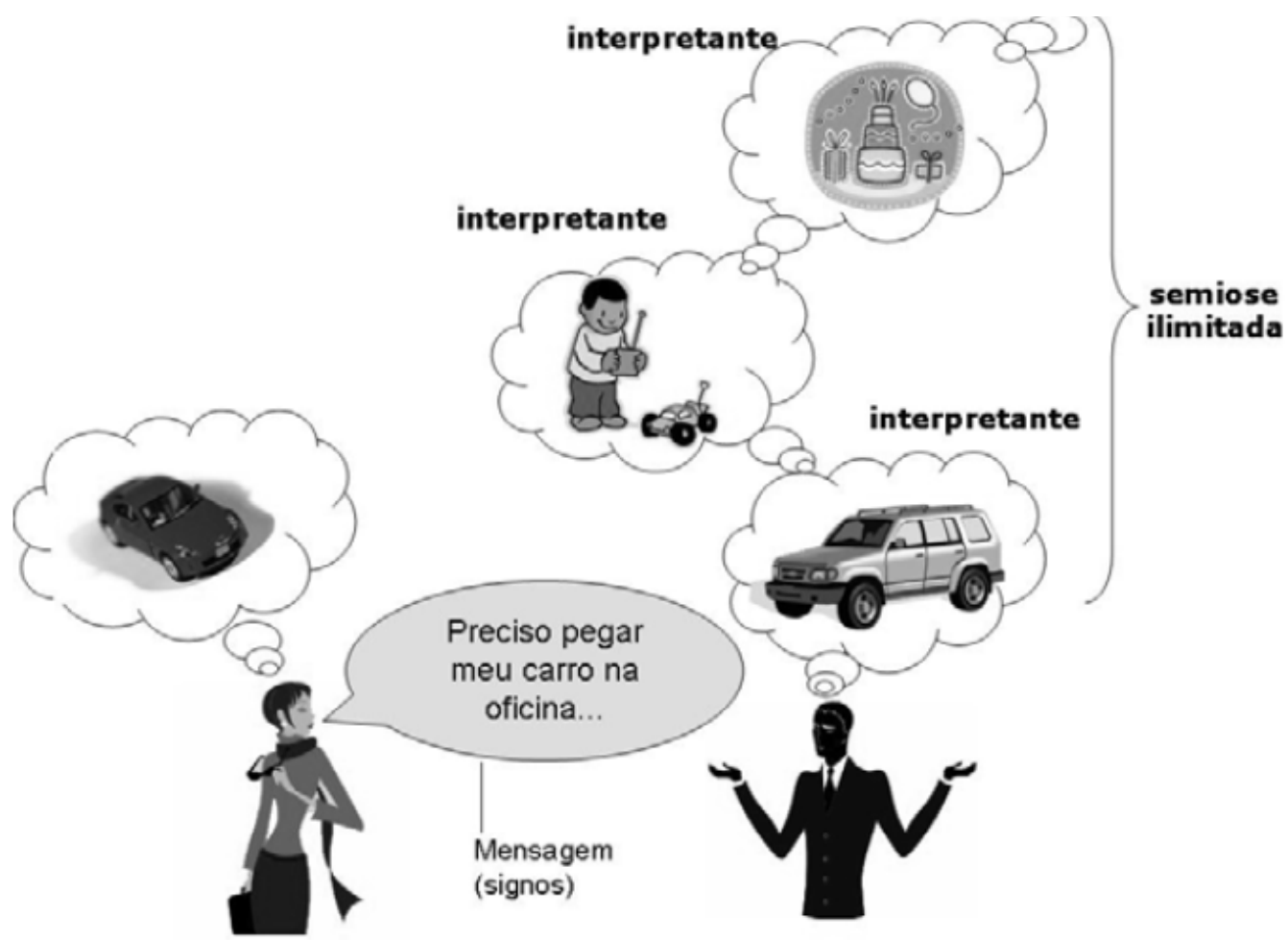

Figura 7: Semiose ilimitada (Prates e Barbosa, 2007, p.270).

A capacidade de criar e usar signos torna possível saber e lembrar o que é sabido. A Semiótica se interessa não apenas pelos signos, mas também em como estes são criados e compreendidos, buscando as raízes biológicas, psicológicas e sociais para a necessidade do ser humano por significado (Danesi e Perron, 1999).

Como outras espécies, o ser humano sempre viveu em grupo, buscando proteção e refúgio. Os primeiros signos foram criados em contextos tribais para auxiliar na forma como nos comunicávamos. As práticas e ações sociais relativas à cultura, como crenças, mitos, valores, instituições e comportamentos, influenciam fortemente a criação e compreensão dos signos. Eco (1976) introduz a cultura como um aspecto determinante em dois processos fundamentais da semiótica: significação e comunicação. Segundo de Souza (2013):

"Significação é a correlação entre conteúdo e expressão. Sistemas de significação são coleções de 'unidades [...] ou vastas porções de discurso, desde que a correlação tenha sido previamente determinada por uma convenção social'. [...] A teoria de produção de signos proposta por Eco define comunicação como um processo que manipula signos, 'considerando ou ignorando a existência [socialmente convencionada] de códigos' (Eco, 1976, p.152)."

Nossa capacidade de resolver problemas e interagir com o ambiente depende amplamente dos artefatos que construímos. Entretanto, nossa interação 
com os artefatos materiais não se limita apenas a seu uso ou função. Siefkes (2012) propõe que esta interação pode ser baseada em:

- função (function-based interaction) - comumente indicadas em seu design, em signos que comunicam funções ou por meio de aprendizado; ou

- $\quad$ significado (meaning-based interaction) - que pode envolver memórias (e.g. a cadeira da vovó), apego emocional (e.g. o chinelo favorito), necessidades psicológicas (e.g. segurança), estilos (e.g. art nouveau), conotação social (e.g. status) ou referências culturais (e.g. óculos usado por um ator em um filme).

De maneira geral, artefatos não são construídos como signos, mas visam primariamente cumprir uma função prática ou estética. No entanto, Danesi e Perron (1999) afirmam que "não há artefato que não esteja impregnado de significado". O exemplo dado por Teixeira, Matos e Perassi (2011) ilustra bem este conceito: “a visão e a utilização de uma cadeira no cotidiano promove sensações, sentimentos e ideias no observador ou usuário; assim, estabelece uma série de significações decorrentes da percepção deste tipo de objeto no mundo". Uma cadeira antiga, além de se expressar como objeto utilitário, pode representar conceitos como descanso e conforto (Teixeira, Matos e Perassi, 2011), ou infância, se associada à memória de "conversas com o vovô quando era criança" (Siefkes, 2012). A interpretação de um signo "sempre depende das experiências de seu intérprete, sua classe social, sexo, etnia, etc.” (Westerlund, 2002).

Toda uma categoria de artefatos pode adotar significados diferentes em diferentes culturas. Um guarda-chuva, por exemplo, em várias culturas é associado à proteção ou segurança. No Japão, no entanto, guarda-chuvas são associados ao amor, pois quando compartilhados por um casal, são considerados uma expressão romântica (Siefkes, 2012).

O contexto em que o artefato se encontra é também um aspecto que influencia o processo de significação. Uma bicicleta adquire diferentes atributos em diferentes contextos, como nova, feminina ou quebrada (Figura 8), mas as características que a identificam como uma bicicleta raramente são modificadas em função do contexto. Figuras geométricas simples encontradas em diversos artefatos, no entanto, "informam muito pouco sobre si mesmas e estão 
normalmente aptas a assumir vários significados em diferentes contextos" (Krippendorff e Butter, 2007).
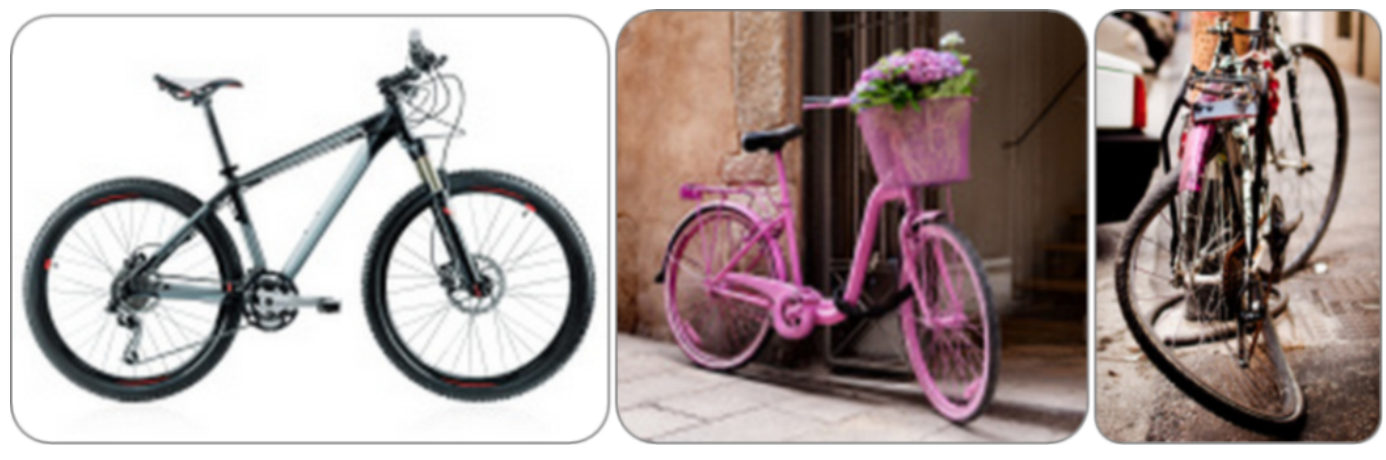

Figura 8: Bicicletas em diferentes contextos. ${ }^{19}$

De acordo com os materiais utilizados em sua fabricação e a composição de sua forma, ${ }^{20}$ um artefato pode gerar diferentes impressões e representar diferentes conceitos. Segundo Teixeira, Matos e Perassi (2011), "os elementos visuais de um objeto [artefato material], em particular ou em conjunto, são considerados signos capazes de configurar a significação do objeto". Além dos elementos visuais, como o formato, as cores e símbolos gráficos, outros elementos também podem ser considerados signos, como textura, cheiro, luzes e sons produzidos pelo artefato, seu posicionamento e o material utilizado (Westerlund, 2002).

O tipo e o modo de utilização do material na construção do artefato tem um grande impacto no que o material expressa. Segundo Karana e Hekkert (2010), o significado de um material se baseia nas interações entre o indivíduo e o artefato e seu(s) material(is). Os autores também afirmam que:

"[...] materiais, além de expressar significados (e.g., moderno, sexy e sóbrio), [...] podem também expressar qualidades particulares dos materiais, como toy-like, business-like, e 'associado com fábricas'. [...] As pessoas associam certos materiais a determinadas formas (e.g., plástico com formas geométricas arredondadas, metal com formas geométricas afiadas). Estas associações se devem principalmente ao uso predominante do material em certa forma em produtos de uso diário".

Os materiais e a forma são referenciados também em outros exemplares, possibilitando sua comparação com artefatos da mesma categoria, produzidos em outros momentos ou lugares (Teixeira, Matos e Perassi, 2011). O escudo de

${ }^{19}$ Imagens de uso gratuito disponíveis no site http://www.istockphoto.com.

${ }^{20}$ Neste trabalho, o conceito de forma engloba características visuais, como formato (feitio, dimensão), cor, luminosidade, articulações e configuração dos elementos visuais, e outras características perceptuais como som, consistência, textura, peso, temperatura, etc.; a forma pode ser estática ou dinâmica. 
plástico apresentado na Figura 9, por exemplo, pelo material utilizado em sua composição, é interpretado como um artefato com finalidade lúdica (brincadeira). O formato arredondado, a estrela e os círculos coloridos na superfície do escudo remetem a uma referência bastante popular em diversas culturas - o herói Capitão América -, reforçando assim a noção de que se trata de um brinquedo.

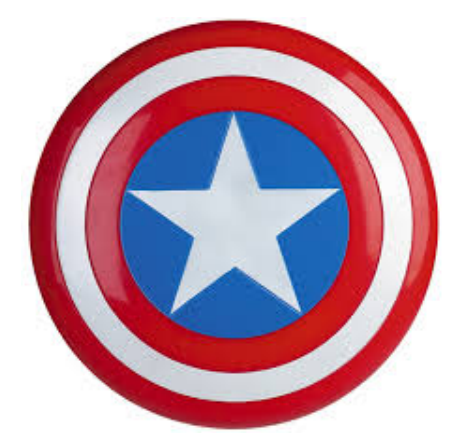

\section{Figura 9: Escudo de plástico.}

Além da análise do corpo do artefato, Mattozzi (2010) ressalta que este não deve ser analisado de modo isolado, mas percebido como "um ponto de interseção em uma rede de relacionamentos (Hjelmslev, 1943)" e que um artefato "toma parte em relações sociais (Latour, 1994 apud Matozzi, 2010), nas quais atua e é usado". Deve, portanto, ser analisado como parte de uma rede que envolve outros atores, a partir das relações que emergem da prática de uso. O artefato per se deve ser considerado um signo e potencial representação de uma categoria e de funções e práticas de uso a ela relacionadas.

\subsection{Conclusão do Capítulo}

Neste capítulo, foram apresentados os principais conceitos e os métodos da Engenharia Semiótica. Foram também apresentados conceitos e exemplos relativos à semiótica e artefatos materiais que reiteram a adequação da semiótica como base teórica para o projeto de TUIs, dentre eles:

- O artefato per se deve ser considerado um signo;

- Um artefato (ou parte dele) pode ser associado a uma categoria e a funções e práticas de uso a ela associadas;

- Os elementos visuais ou propriedades de um artefato, em particular ou em conjunto, são signos capazes de configurar a significação do artefato num dado contexto; e

- A maneira como os usuários interagem com um artefato depende de seu material, sua forma e das relações que emergem da prática de uso. 
A Engenharia Semiótica é uma teoria explicativa de IHC fundamentada na semiótica, com foco na comunicação entre designers, usuários e sistema. De diversas maneiras, direta ou indiretamente, os designers comunicam (intencionalmente) aos usuários como podem ou devem interagir com o sistema através de sua interface. A noção de que a interação humano-computador é uma comunicação humana mediada por computador introduzida pela Engenharia Semiótica centra o projeto do tangível em sua comunicabilidade e fomenta questionamentos sobre o que os designers sabem sobre o usuário, que problemas a interface pode resolver e como interagir com ela.

Por ser fundamentada na semiótica, a Engenharia Semiótica abrange a percepção do tangível tanto com relação a sua funcionalidade (práticas de uso) como a seu significado. Consequentemente, possibilita (ou até mesmo facilita) a incorporação ao projeto de intenções do designer não relacionadas diretamente à função do tangível, como torná-lo mais divertido, surpreendente ou subversivo. A Engenharia Semiótica possibilita a percepção da interface como um artefato material construído intencionalmente e impregnado de significados, desta forma se caracterizando como uma abordagem adequada ao projeto de tangíveis. 


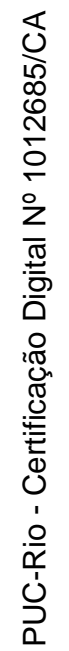




\section{4}

\section{Prototipação Colaborativa de Tangíveis Baseada na Engenharia Semiótica}

O método proposto, denominado Prototipação Colaborativa de Tangíveis Baseada na Engenharia Semiótica, combina as abordagens de prototipação e da Engenharia Semiótica no projeto de interfaces tangíveis. Ao combinar estas abordagens, o método agrega os benefícios da experimentação continuada de forma estruturada proporcionada pela prototipação com as vantagens do foco na comunicabilidade da Engenharia Semiótica no projeto de tangíveis.

Este método se origina de um método de prototipação já existente denominado Prototipação Colaborativa de Tangíveis (Cardador et al., 2013), desenvolvido por uma equipe do LES/SecondLab da PUC-Rio, por meio de pesquisa-ação $^{21}$ envolvendo a aplicação deste método no projeto de interfaces tangíveis em diferentes contextos de ensino e pesquisa, de março de 2011 a dezembro de 2013. Para a incorporação da perspectiva da Engenharia Semiótica a este método, este foi adaptado de modo a promover a aplicação de conceitos de Engenharia Semiótica ao longo do processo de prototipação. É importante ressaltar que o método proposto não tem como pré-requisito o conhecimento prévio de conceitos de Engenharia Semiótica e, por este motivo, este também contempla a aquisição destes conceitos.

O método aqui proposto, bem como o original, adota uma abordagem de prototipação. A prototipação possibilita refazer o que estamos fazendo, enquanto estamos fazendo. É esta experimentação contínua que auxilia o designer a encontrar uma solução viável para sua necessidade, não com um método de tentativa-e-erro, mas por meio de decisões fundamentadas e ações intencionais. O método proposto utiliza tecnologias disponíveis - plataformas de prototipação -

21 A pesquisa-ação procura unir a pesquisa à ação ou prática. Na pesquisa-ação, “o pesquisador conduz as ações, participa do ambiente em que as investigações são realizadas e relata suas observações e impressões do que vivenciou" (Filippo, 2008). 
para o desenvolvimento de protótipos de alta fidelidade, que "dão forma" às ideias e possibilitam avaliar a integração entre forma e comportamento, dois componentes centrais da interação com tangíveis.

Protótipo é um primeiro exemplar, usado como um modelo a partir do qual outros exemplares são criados, ou como uma base ou padrão para outras etapas de desenvolvimento de um produto (Arnowitz, Arent e Berger, 2007). Schrage (1993) acrescenta que "mais que simples modelos, protótipos são indicadores da cultura de uma empresa e de sua habilidade de inovação”. A prototipação é uma abordagem para o desenvolvimento de protótipos com um ciclo de vida bem definido que envolve o projeto, a construção do protótipo e sua avaliação (Figura $5)$.

A prototipação possibilita a experimentação de sucessivas versões de um artefato de forma rápida e auxilia na obtenção de feedback de usuários e desenvolvedores. Segundo Arnowitz, Arent e Berger (2007), este tipo de abordagem possibilita explorar e testar ideias, validar suposições e requisitos de design e comunicar ideias para um grupo interdisciplinar. No estágio inicial de desenvolvimento, reduz custos e os riscos de "poor design" (Arnowitz, Arent e Berger, 2007; Wiethoff et al., 2012), uma vez que agiliza a adequação do projeto, os ajustes em sua construção e novos testes. Um protótipo não precisa ser completo, ou seja, não é necessário que ele contenha todas as funcionalidades previstas para o produto final. A construção de um protótipo pode ter por objetivo testar ou validar aspectos ou partes específicas do produto em desenvolvimento.

Há diferentes métodos de prototipação que visam etapas distintas do desenvolvimento de produtos. Em função do grau de similaridades entre o protótipo resultante e o produto idealizado, os métodos de prototipação são:

- Prototipação de Baixa Fidelidade (Low-fi) - prototipação rápida (Beaudouin-Lafon e Mackay, 2007), com baixo investimento de tempo e recursos em sua construção e modificação; mais indicada para a fase de concepção do produto; resultam em artefatos sem adição de funcionalidade, como no caso de croquis e storyboards, ou modelos com funcionalidade(s) relacionada(s) à forma, como maquetes e mockups; ${ }^{22}$

${ }^{22}$ Segundo Paschoarelli, Silva e da Silva (2011), “mockup é um modelo físico em escala real (escala 1:1), da proposta de produto, cujas dimensões e forma são fidedignos àquelas que assinalam o design proposto". 
- Prototipação de Alta Fidelidade (Hi-fi) - mais próximos do que serão os produtos, os protótipos Hi-fi são detalhados e representam claramente os aspectos estéticos e os componentes envolvidos; partes do protótipo podem ser reutilizadas no produto; mais indicados para a fase final do desenvolvimento do produto;

- Prototipação de Média Fidelidade - este tipo de prototipação combina características das prototipações Low-fi e Hi-fi; usualmente envolvem o uso de algum tipo de tecnologia para simular funcionalidades, como, por exemplo, o método Video Prototyping (Young e Greenlee, 1992) que usa animação/vídeo para a simulação das funcionalidades.

Em computação, a prototipação é uma abordagem baseada numa visão evolutiva do desenvolvimento de software. São exemplos de métodos de prototipação utilizados no desenvolvimento de sistemas:

- Low-fi - este tipo de prototipação dá ênfase ao projeto da interface, usualmente por meio da representação de telas estáticas, com interação por meio de testes simulados; o Paper Prototyping (Snyder, 2003) é um exemplo de método de prototipação específico para GUIs, que resulta em um protótipo construído com papel e com avaliação baseada na simulação do uso da interface (Figura 10).

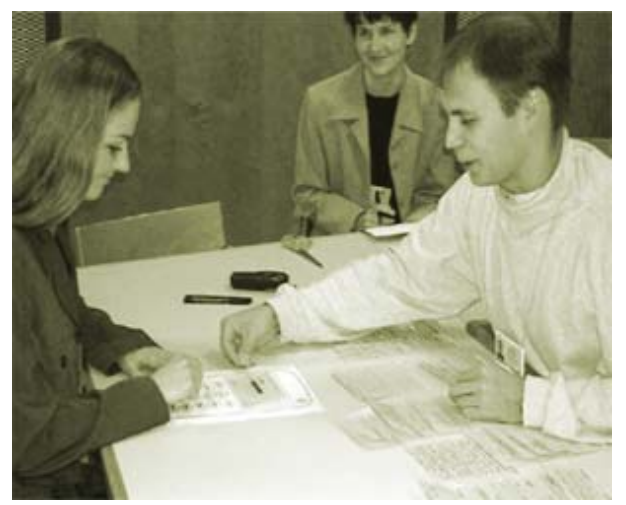

Figura 10: Teste de usabilidade do Paper Prototyping (Snyder, 2003).

- Média Fidelidade - os protótipos de média fidelidade consistem em implementações computadorizadas contendo parte das funções previstas no sistema, utilizadas para avaliar alguns cenários ou para suporte a estudos com o usuário; o DENIM (Design Environment for Navigation and Information Models) é um exemplo de sistema (Lin, Thomsen E Landay, 2002) que dá suporte à construção de protótipos de média 
fidelidade em estágios iniciais do processo de concepção do sistema; este auxilia o designer na elaboração de interfaces, possibilitando a criação dos esboços das páginas e inserção de links de forma rápida (Figura 11).

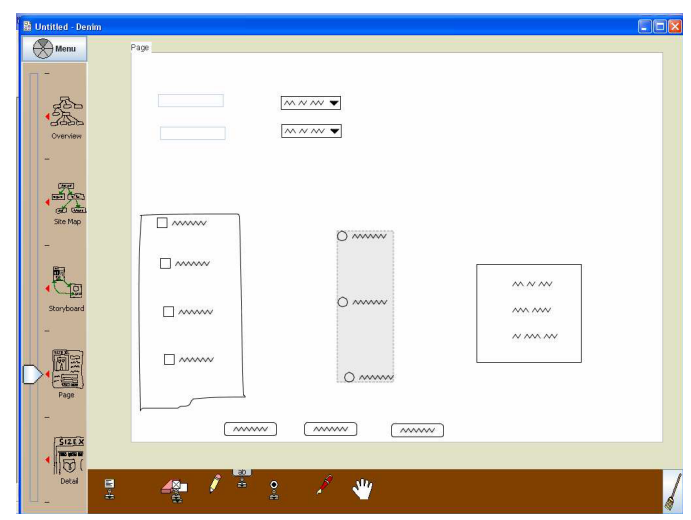

Figura 11: Exemplo de esboço utilizando o DENIM (Lin, Thomsen E Landay, 2002).

- Hi-fi - esses protótipos contêm as principais funcionalidades presentes no futuro sistema e são construídos com o uso de uma linguagem de programação; os aspectos estéticos (padrão, fonte, cor, tamanhos de botões, etc.) e os componentes de navegação são claramente definidos (Aguiar et al., 2007).

A maioria dos métodos de prototipação de sistemas enfoca o desenvolvimento de GUIs, não considerando aspectos relacionados a outras formas de interação. No caso de TUIs, um dos aspectos fundamentais a ser considerado é a forma do tangível. Paschoarelli, Silva e da Silva (2011, p.328), ressaltam a importância da representação física de um instrumento (neste caso o tangível) no desenvolvimento de um produto ou sistema:

"Testes de usabilidade aplicados no desenvolvimento de projetos de instrumentos manuais demonstram serem procedimentos essenciais para a avaliação e validação ergonômica do produto ou sistema. Tais testes exigem, entre outros aspectos, a manipulação do instrumento manual, então caracterizado - ou materializado - na forma de um modelo físico tridimensional".

Este texto trata especificamente de instrumentos manuais, mas este conceito pode ser ampliado para outros tipos de instrumentos que envolvam outras formas de interação física direta com o usuário. Vale ressaltar que no caso de TUIs, a representação física possibilita a avaliação não só dos aspectos ergonômicos, mas também de aspectos relativos à interação com o usuário. 
Segundo de França e do Amaral (2013), é indicado que o protótipo Hi-fi seja desenvolvido apenas após a otimização do projeto por meio de testes com um protótipo Low-fi. Tendo isto em vista, o método aqui proposto, denominado Prototipação Colaborativa de Tangíveis Baseada na Engenharia Semiótica, é composto por três etapas: (1) Prototipação da Forma, (2) Prototipação do Comportamento e (3) Prototipação do Artefato. As etapas, apresentadas na Figura 12, seguem o ciclo de vida de prototipação - planejamento, construção e avaliação - e resultam no protótipo Hi-fi da interface tangível. Cada uma das três etapas compreende um método de prototipação específico, que atende aos objetivos, necessidades e características daquela etapa. O método proposto é resultante da composição destes métodos.

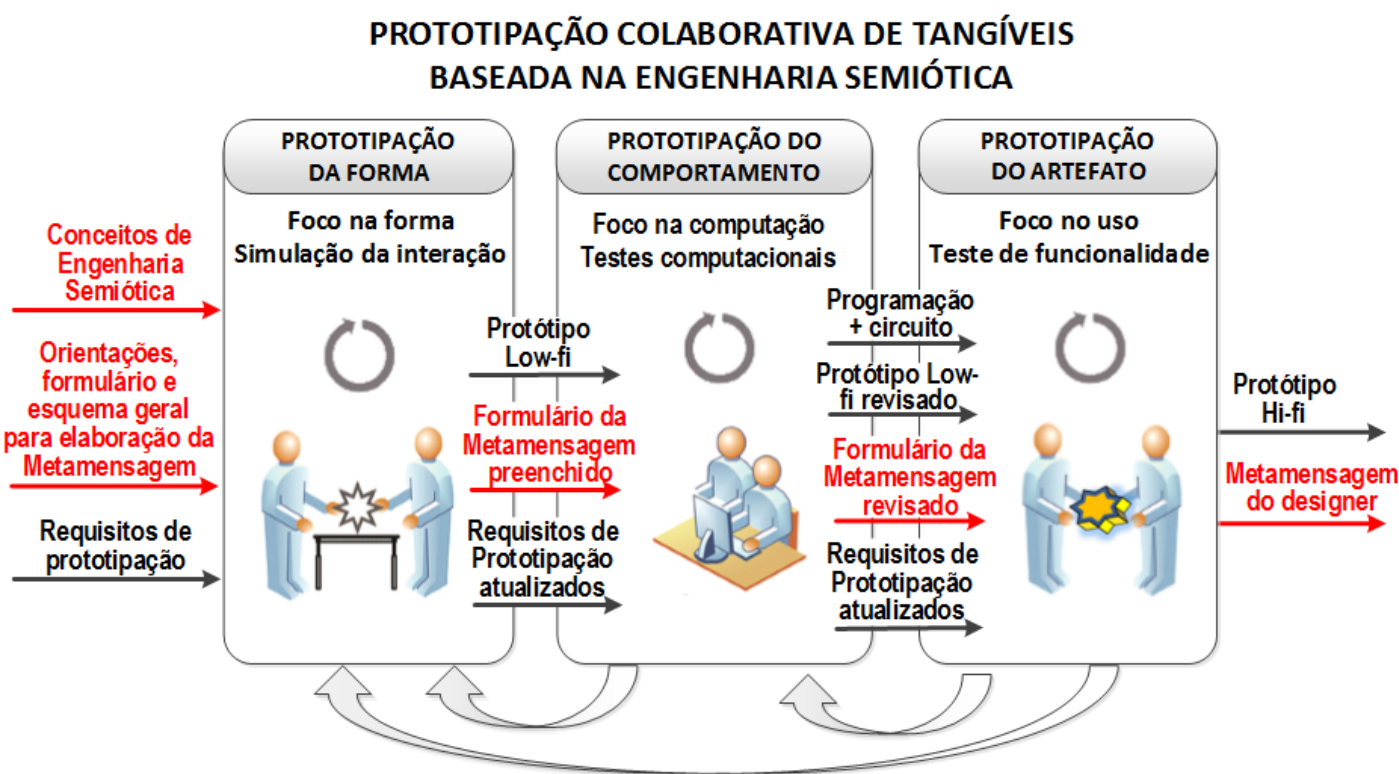

Figura 12: As três etapas da Prototipação Colaborativa de Tangíveis Baseada na Engenharia Semiótica.

Os itens destacados na Figura 12 identificam as alterações efetuadas no método de prototipação original, que visam promover a aquisição e aplicação de conceitos de Engenharia Semiótica. Nota-se na Figura 12 que o método resulta na Metamensagem do Designer, além do protótipo Hi-fi.

Assim como o método original (Prototipação Colaborativa de Tangíveis), o método proposto pode ser utilizado em diferentes contextos, como projetos de pesquisa, no ensino ou como parte do processo de desenvolvimento de produto. No caso do contexto educacional, o método de prototipação pode ser incorporado ao método pedagógico visando promover o aprendizado, como a experiência 
relatada por Cardador et al. (2013), ou ser adotado como um método comum para interface desenvolvidas pelos alunos.

Caso nenhum dos participantes tenha experiência anterior com este método, sugere-se, se possível, a participação de um facilitador com esta experiência, que atue orientado o grupo. No entanto, a participação de um facilitador não é condição necessária para que o método seja empregado. É importante destacar que o papel do facilitador se resume a fornecer aos participantes orientações e recursos (conceitos, formulários, modelos, exemplos) necessários para a aplicação do método e, dependendo do contexto, prover os recursos necessários para a construção do protótipo, como no caso de contexto de ensino, no qual o professor assume o papel de facilitador.

\subsection{Preparação para Aplicação do Método}

\subsubsection{Requisitos de prototipação}

A prototipação parte de um conjunto de requisitos que fornecem a base necessária para o desenvolvimento do protótipo, denominados requisitos de prototipação. Requisitos de prototipação não devem ser confundidos com requisitos de software. Na construção de um protótipo, geralmente, não é necessário incluir requisitos tais como desempenho e aspectos de segurança. Os requisitos de prototipação devem explicitar os objetivos a serem alcançados, características desejadas, perfil de usuário e outras informações pertinentes ao desenvolvimento do protótipo. O levantamento destes requisitos é feito a priori e, geralmente, não é incluído no método de prototipação.

O levantamento de requisitos de prototipação pode empregar diferentes abordagens e métodos, priorizando a compreensão do problema e dos usuários do protótipo/produto. No método de levantamento de requisitos proposto por Arnowitz, Arent e Berger (2007), por exemplo, os requisitos de prototipação partem de pressupostos, que são identificados, inventariados e priorizados, resultando em uma tabela de requisitos. Outro exemplo de método para levantamento destes requisitos é apresentado por Moura et al. (2012), que utiliza uma abordagem centrada no usuário e combina diferentes técnicas, como observações diretas, entrevistas e co-design. 
O método Prototipação Colaborativa de Tangíveis Baseada na Engenharia Semiótica pode ser utilizado em diferentes contextos, cada contexto com motivações e necessidades específicas com relação aos requisitos de prototipação. Por exemplo, quando o método é aplicado como parte do método de ensino, visando promover o aprendizado, os requisitos se baseiam fundamentalmente nas necessidades e limitações do contexto educacional (objetivos, duração, perfil dos alunos, recursos disponíveis). No desenvolvimento de produto, aspectos como custo, durabilidade do produto final e sua manutenção devem ser contemplados.

No caso deste método, os requisitos de prototipação se confundem com os requisitos de design, uma vez que o objetivo da prototipação é o desenvolvimento de uma interface tangível. No entanto, o levantamento de requisitos ocorre em etapas distintas em cada caso. Na prototipação, este levantamento é feito a priori, enquanto o levantamento de requisitos de design é tipicamente uma fase inicial no desenvolvimento do projeto de interface. Tendo isto em vista e considerando a variedade de contextos de aplicação, optou-se por não incluir o levantamento de requisitos como parte integrante do método, mas deixar em aberto esta questão para que a equipe de design escolha o método que julgar mais adequado ao contexto em questão. Os requisitos serão considerados pré-requisitos para a aplicação do método.

Independente do tipo de método de levantamento adotado pela equipe de design, visando organizar e homogeneizar a descrição dos requisitos e garantir que estes contenham as informações mínimas necessárias para a aplicação do método, define-se um conjunto de itens padronizados para a descrição dos requisitos:

1. Informações sobre o perfil de usuário e contexto - descrição geral, objetivos, necessidades e preferências dos usuários e informações sobre o contexto (escopo) de uso do protótipo;

2. Critérios - características gerais do protótipo, como, por exemplo, "deve apoiar a interação entre usuários", "prover entretenimento" ou "ser amigável para iniciantes em tecnologia";

3. Diretrizes - descrição de características específicas, como funcionalidades, aspectos físicos ou tecnológicos, restrições financeiras ou relativas a outros recursos, etc.; por exemplo: "interface baseada em água"; "as leituras dos RFIDs contidos nas unhas são a única forma de 
leitura a ser utilizada"; "o protótipo deve ser desmontável e seus componentes devem caber em um container com $72 \times 48 \times 28 \mathrm{~cm}$ e ter peso máximo de $23 \mathrm{~kg}$ ” e "o tangível se comunica com o servidor através de rede sem fio segura por meio do uso de módulos XBee" (Faludi, 2008); e

4. Cenários de uso - descrevem de maneira sucinta os cenários a serem contemplados nos testes de uso do protótipo com usuários.

A definição destes itens não se baseia em um método de levantamento de requisitos específico. Estes foram definidos de forma empírica, a partir das experiências com a utilização do método de prototipação original em diferentes contextos.

\subsubsection{Conceitos de Engenharia Semiótica, orientações, formulário e esquema geral para elaboração da Metamensagem}

Para que o método proposto seja bem sucedido, é necessário que os designers efetivamente adotem uma perspectiva centrada na comunicação designer-usuário mediada pela interface no projeto do tangível. Com esta finalidade, foram incorporadas ao método de prototipação original atividades que atuam como pontos focais de aplicação dos conceitos de Engenharia Semiótica. As atividades propostas são: (i) a elaboração da metamensagem do designer e (ii) a avaliação da interface com base na metamensagem. Os conceitos de Engenharia Semiótica adotados são aqueles considerados fundamentais para que os designers possam realizar estas atividades. São eles:

a. O projeto de interfaces deve ter como foco principal a comunicação designers-usuários mediada pela interface;

b. O artefato comunica uma mensagem do designer para os usuários sobre o que o faz, como pode ser utilizado e por quê.

c. A interface comunica ao usuário, durante a interação, a metamensagem do designer sobre o que sabem sobre o usuário, que problemas a interface pode resolver e como interagir com ela.

Tendo em vista que o método pode ser empregado sem que os designers necessitem ter conhecimento prévio de conceitos de Engenharia Semiótica, a introdução destes conceitos é prevista no método e deve ser realizada de forma breve e resumida, antes do início da prototipação. Esta introdução deve: 
- Utilizar linguagem adequada ao perfil dos designers;

- Incluir uma breve introdução sobre Engenharia Semiótica;

- Incluir exemplos de comunicação designers-usuários mediada pela interface;

- Incluir a definição, esquema geral da metacomunicação e exemplos de metamensagem.

Caso haja um facilitador orientando o grupo, este pode conduzir a introdução dos conceitos, mas caso a equipe não conte com o auxílio de um facilitador, indica-se a leitura de trecho introdutório do Capítulo 3 (p. 30-22). A introdução de conceitos de Engenharia Semiótica somente é dispensável caso todos os designers já tenham participado da aplicação do método anteriormente.

A elaboração da metamensagem passa por duas fases: a primeira envolve o preenchimento de um formulário específico, denominado Formulário de Metamensagem, a segunda visa o preenchimento do esquema geral da metacomunicação (p.22). O formulário é preenchido pela equipe de design na etapa inicial de prototipação, na qual é utilizado para a avaliação do protótipo Low-fi. O Formulário de Metamensagem contém os campos que correspondem às informações necessárias para o preenchimento do esquema geral da metacomunicação. São eles:

(1) Quem é o usuário?

2 O que ele quer ou precisa fazer?

3 De que maneira ele prefere fazê-lo e por quê?

4 Qual o sistema projetado?

5 De que forma ele pode ou deve ser utilizado?

A finalidade do formulário é proporcionar uma forma de registro da metamensagem na fase inicial de prototipação de forma simplificada. O formulário preenchido é utilizado nas etapas de prototipação seguintes, servindo na etapa final como base para a segunda fase de elaboração da metamensagem, que emprega o esquema geral da metacomunicação proposto por de Souza (2005):

"Este é o meu entendimento de (1)quem você é, 2 do que entendi que você quer ou precisa fazer, 3 de que maneira você prefere fazer, e por quê. Este, portanto, 4 é o sistema que projetei pra você, e 5 é a forma como você pode ou deve utilizá-lo para alcançar uma gama de objetivos que se encaixam nesta visão." 
Esta metamensagem é utilizada na fase avaliação do protótipo Hi-fi (etapa final) como referência para os testes com usuários Hi-fi. Esta mensagem é também uma das saídas do método, provendo uma importante documentação sobre o projeto desenvolvido.

\subsection{Prototipação da Forma}

O objetivo principal nesta etapa é a concepção da interface e sua avaliação por meio da construção de um protótipo físico Low-fi, dando enfoque à forma do protótipo e sua interação com o usuário. É fundamental que o método adotado nesta etapa possibilite a experimentação 'rápida' com diferentes ideias relativas à forma e à interação com o usuário.

O método de prototipação proposto para esta etapa é derivado do método de Prototipação Blank Model (Blank Model Prototyping - BMP), descrito por Arnowitz, Arent e Berger (2007). O BMP é um método de prototipação rápida que utiliza role-playing e materiais facilmente disponíveis na construção de representações rústicas de um conceito tecnológico, de acordo com um determinado cenário (Moura et al., 2012). Seu objetivo é "coletar impressões e ideias de potenciais usuários sobre uma tecnologia de hardware ou software inexistente, incluindo funções requeridas, controles e necessidades de interação" (Arnowitz, Arent e Berger, 2007). No BMP, é criada uma representação física da forma e suas funções, enquanto o comportamento é simulado para possibilitar uma investigação inicial sobre a adequação forma-comportamento e sobre a interação com o usuário. A Prototipação da Forma (Figura 13) se baseia no BMP, especialmente nas etapas de planejamento e construção, mas foram feitas alterações no método original relativas à duração de atividades, à necessidade de colaboração e, principalmente, com relação à avaliação do protótipo. Neste último caso, visando a incluir a aplicação de conceitos de Engenharia Semiótica. 


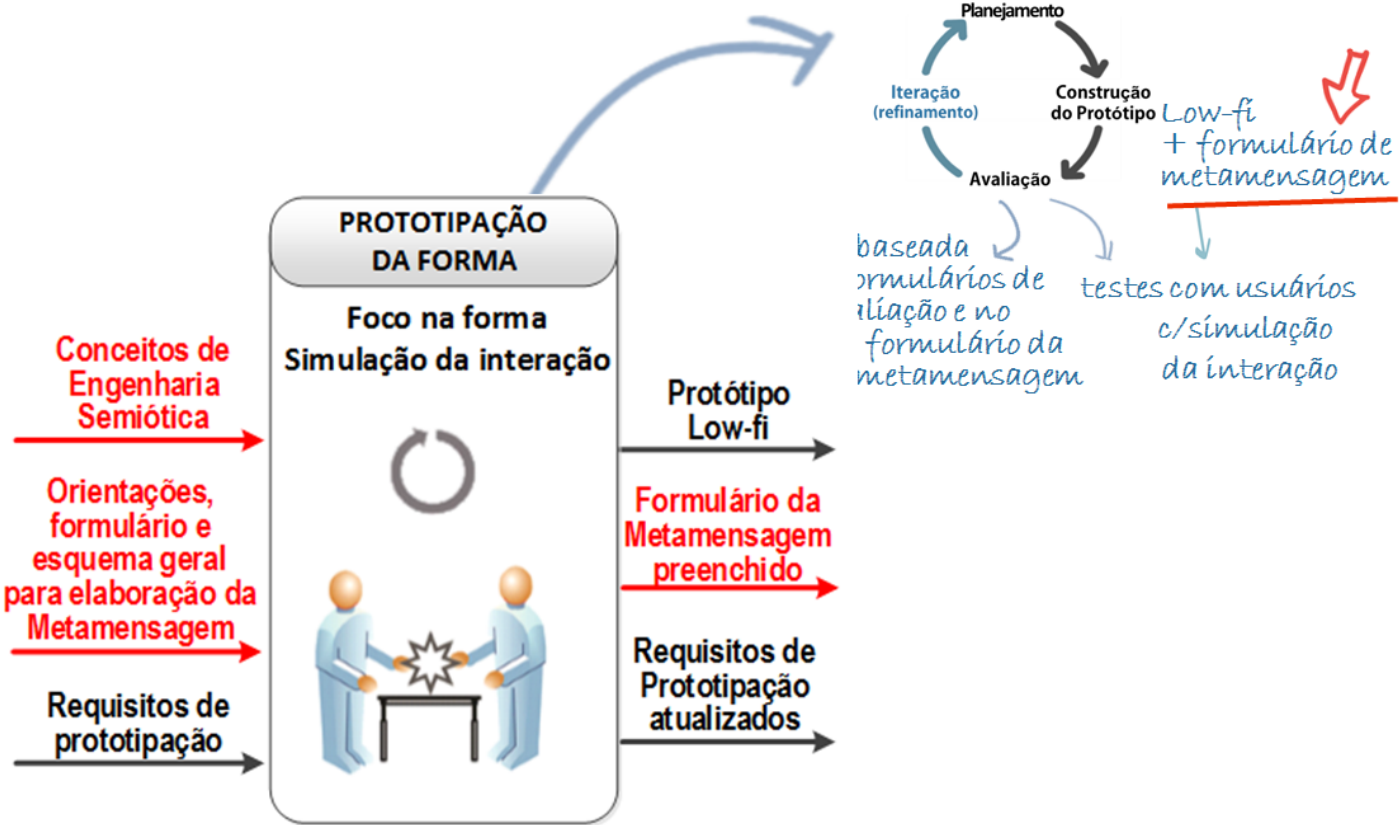

Figura 13: Prototipação da Forma.

$\mathrm{Na}$ fase de planejamento (Figura 14-P), ocorre a ideação da interface, registrada por meio de esboço e anotações. Nesta etapa, é importante que a equipe discuta alguns dos aspectos tecnológicos envolvidos na construção do tangível, especificamente sobre os componentes físicos (computacionais ou eletrônicos) necessários para a futura implementação do protótipo $\mathrm{Hi}$-fi, uma vez que a quantidade, forma e tamanho destes componentes podem impactar a forma do tangível. Os protótipos Low-fi construídos nesta etapa devem ser suficientemente detalhados para os testes com simulação, mas não necessitam ser duráveis, uma vez que não serão utilizados como parte do protótipo Hi-fi.

A fase de construção do protótipo Low-fi (Figura 14-C) visa criar a representação de um conceito tecnológico empregando materiais de fácil acesso, como papel, tecido, canetas coloridas e fita crepe. Além do protótipo (Figura 14L), ao término desta fase, os designers devem preencher o Formulário de Metamensagem. 


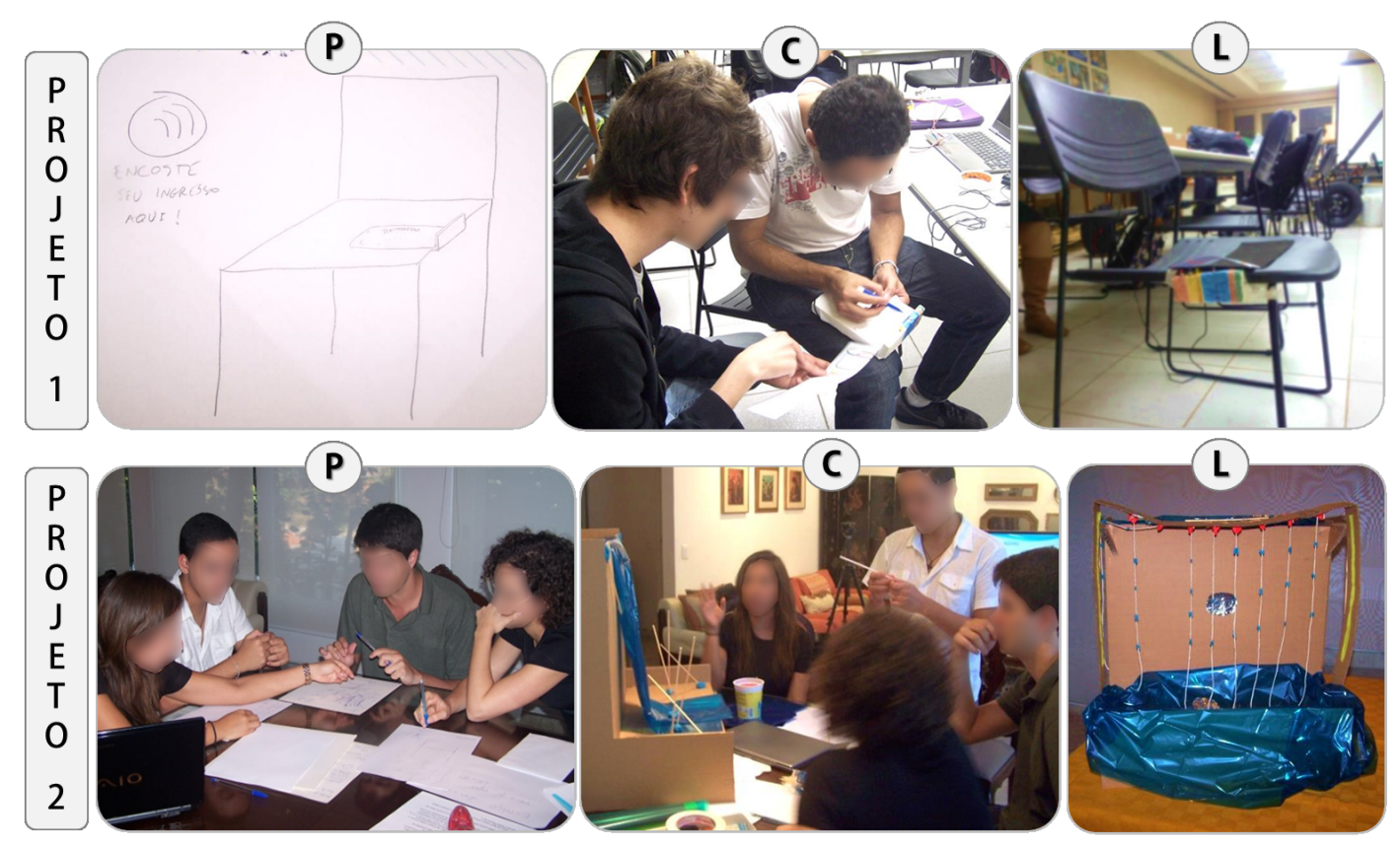

Figura 14: Exemplos de Prototipação da Forma.

O teste é simples e rápido: o usuário é informado sobre a natureza da interface (o que, e.g.: é uma cadeira, um boné, um convite) e seu propósito (para o que é utilizado, e.g.: valida o ingresso, move o mouse na tela, informa sobre um evento). Em seguida, é orientado a examinar o artefato e executar determinadas tarefas, definidas a partir dos Cenários de Uso contidos nos requisitos de prototipação, sem que sejam dadas orientações sobre como a interface deve ser utilizada. Por exemplo: "Este é uma cadeira utilizada em eventos que auxilia o usuário na localização de seu assento e na solicitação de atendimento da equipe do evento. Você deve validar seu ingresso para poder utilizar a cadeira e, depois, abrir uma chamada de atendimento" (Figura 14-Projeto 1). A dinâmica de exploração da interface e identificação da forma de utilização pelo usuário possibilita aos designers observarem e analisarem aspectos da comunicação designer-usuário mediada pela interface.

Como o protótipo é uma representação, o teste é realizado com a simulação das funcionalidades previstas para a interface, envolvendo os seguintes papéis:

- Usuário - participante externo, não pertencente à equipe de projeto; deve atender ao perfil definido nos requisitos;

- Facilitador - participante da equipe que orienta o usuário durante a avaliação, dando as informações necessárias para o teste; 
- Computador - participante da equipe que simula as operações de E/S que seriam realizadas pelo computador em resposta às ações do usuário;

- Observador - participante da equipe que faz observação direta das ações do usuário e registra no Formulário de Avaliação os pontos considerados pertinentes para análise do grupo.

São necessários pelo menos três participantes além do usuário para a realização do teste (facilitador, computador e observador). Caso a equipe seja formada por apenas dois componentes, os papéis de facilitador e computador podem ser acumulados. Caso a equipe seja composta por mais de três designers, podem-se incluir outros observadores no teste, desta forma possibilitando que mais dados sejam coletados para posterior análise do grupo acerca do teste. Cada observador deve utilizar um formulário individual. É recomendado registrar o teste através de gravação de vídeo. O vídeo poderá servir como fonte para consulta no caso de dúvidas da equipe sobre o teste durante a sua análise.

Após a realização do teste, os designers analisam os pontos considerados pertinentes por meio de discussão em grupo, comparando o que foi observado e registrado no Formulário de Avaliação com as informações sobre o projeto contidas no Formulário de Metamensagem. Os resultados desta discussão devem ser incluídos no Formulário de Avaliação, nos campos "Modificações indicadas" e "Recomendações relativas ao protótipo para iterações ou etapas seguintes". Algumas recomendações resultantes da avaliação podem ser necessárias para o desenvolvimento de etapas de prototipação, como, por exemplo, observações sobre peso ou dimensão do tangível, ou indicação sobre o uso de um material ou posicionamento de um componente na construção do protótipo Hi-fi. Estas recomendações devem ser incluídas nos Requisitos de Prototipação. Este método admite a atualização dos requisitos de prototipação, com a inclusão de itens definidos pelos designers no conjunto de requisitos iniciais, desta forma possibilitando que resultados, conclusões e observações de uma etapa sejam considerados nas etapas seguintes.

As iterações de prototipação são rápidas, de modo a possibilitar vários ciclos de planejamento, construção e avaliação pela equipe. No caso de iteração, o Formulário de Metamensagem é revisado e o protótipo Low-fi é adaptado ou refeito de modo a incorporarem as alterações definidas na avaliação anteriormente realizada, indicadas no Formulário de Avaliação. Ao final desta etapa, obtém-se 
um protótipo Low-fi testado de forma iterativa, o Formulário da Metamensagem preenchido, e recomendações resultantes da avaliação, que são utilizados como subsídio para as etapas posteriores de prototipação.

Uma questão importante a ser abordada é a quantidade de testes com usuário necessários a cada iteração de prototipação. $\mathrm{O}$ objetivo da avaliação do protótipo é identificar necessidades de ajustes no projeto, desta forma, promovendo o aperfeiçoamento do protótipo a cada iteração. A prototipação, como aqui proposta, deve ser rápida e, portanto, não deve envolver um grande número de testes de usuários a cada iteração. Deve-se ressaltar que estas avaliações não são avaliações de usabilidade. Seu objetivo é identificar rupturas de comunicação. Caso uma ruptura seja identificada já no primeiro teste, não há necessidade de se proceder outros testes na mesma iteração, a não ser que a equipe deseje confirmar suas conclusões e para isso opte por efetuar outros testes com usuário(s) com perfis distintos. Caso o teste não tenha resultado em uma indicação de ajuste, antes de encerrar o ciclo e concluir a etapa a equipe deverá verificar se há necessidade de realização de outros testes, considerando as seguintes questões:

- Os participantes dos testes realizados representam a diversidade de perfis de usuário?

- Algum dos ajustes efetuados deve ser validado por algum tipo de perfil de usuário específico?

Tendo estas questões em vista, o método não propõe um número mínimo ou máximo de testes com usuário. Caso a equipe julgue que os testes realizados foram suficientes, deve dar esta etapa de prototipação como concluída.

\subsection{Prototipação do Comportamento}

Na Prototipação do Comportamento, o objetivo é desenvolver o programa e construir o circuito que serão partes integrantes do protótipo Hi-fi. O protótipo Low-fi, juntamente com o Formulário da Metamensagem preenchido, as recomendações da avaliação e os requisitos de prototipação definidos são os pontos de partida para o desenvolvimento do código de programação e circuitos nesta etapa (Figura 15) e direcionam o trabalho de implementação. 


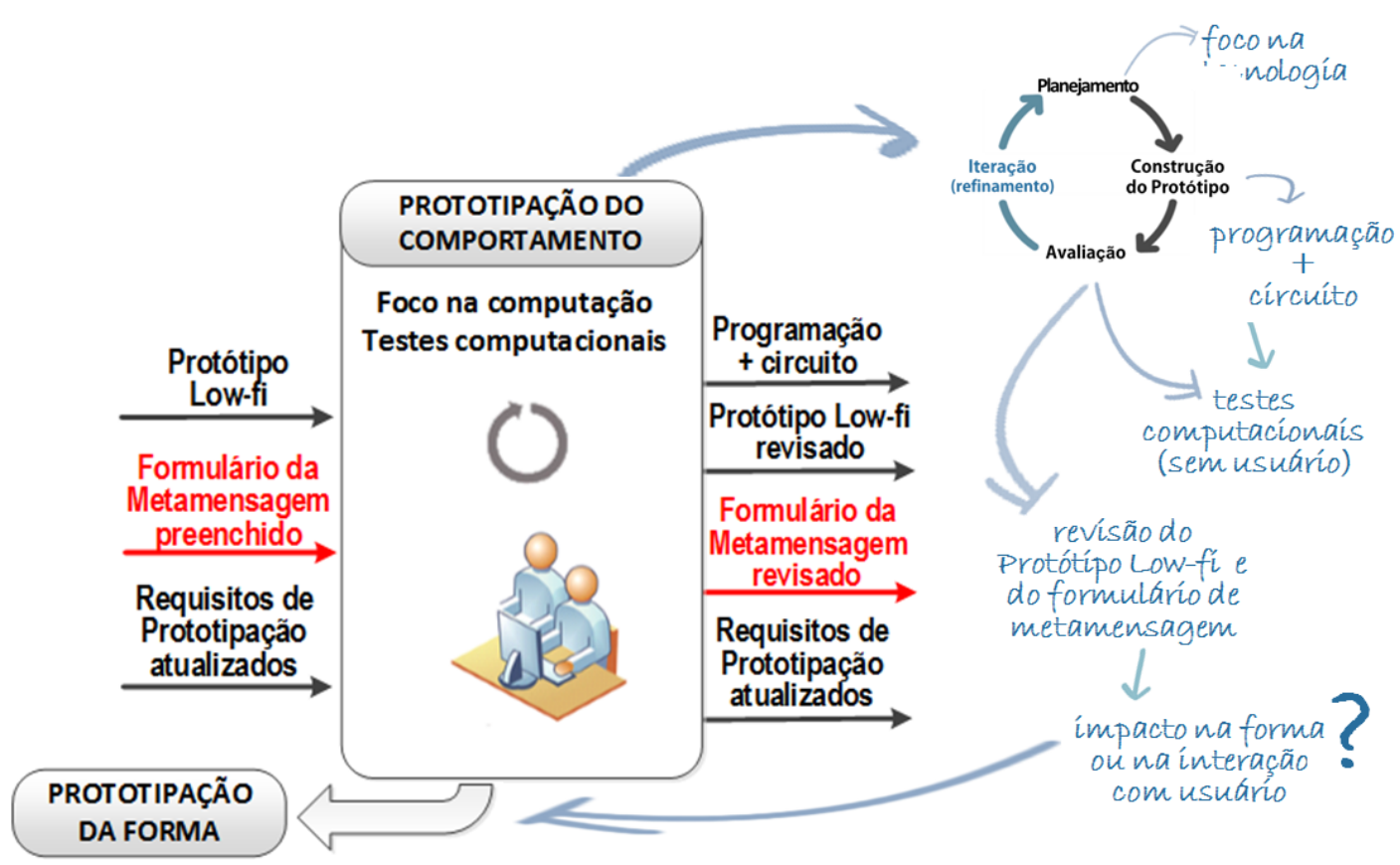

Figura 15: Prototipação do Comportamento.

O protótipo Low-fi desenvolvido na etapa anterior cumpre um papel importante no desenvolvimento desta etapa, uma vez que "a prototipação do código deve ser precedida por métodos mais rápidos e baratos de prototipação para testar determinados aspectos críticos" (Arnowitz, Arent e Berger, 2007). Mas, diferentemente do protótipo Low-fi, o protótipo resultante desta etapa (programa e circuito) será parte integrante do tangível, configurando um caso de prototipação evolucionária (Beaudouin-Lafon e Mackay, 2009).

O planejamento desta etapa envolve: um esboço mais detalhado do tangível, a definição da plataforma de prototipação (caso não esteja descrita nos requisitos ou não tenha sido definida pela equipe na etapa anterior) e a seleção dos componentes eletrônicos e de computação e demais materiais necessários para a construção do circuito.

Por envolver o desenvolvimento de código de programação, o método utilizado nesta etapa é a Prototipação Codificada (Coded Prototyping), proposta por Arnowitz, Arent e Berger (2007). Com base nos Cenários de Uso definidos nos requisitos de prototipação, a cada iteração de prototipação são aplicados os seguintes passos na avaliação do protótipo:

1. Selecionar cenário;

2. Identificar os elementos de interface com o usuário para o cenário selecionado; 
3. Implementar os elementos de interface - programa e circuito;

4. Testar a implementação para o cenário selecionado;

5. Revisar o protótipo - programa e circuito.

O uso de uma plataforma de prototipação implica na implementação simultânea do programa/software e do circuito/hardware, durante a fase de construção do protótipo (item 3), como ilustra o exemplo da Figura 16.

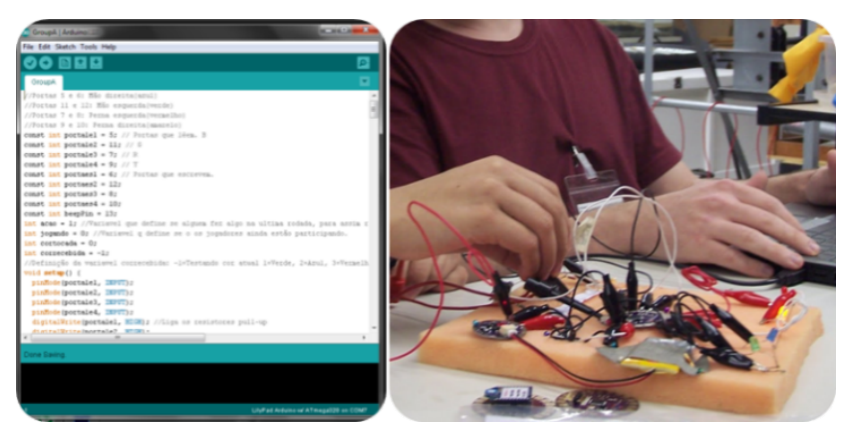

Figura 16: Exemplo de circuito e programação implementados com a plataforma Arduino.

A avaliação (itens 4 e 5) é realizada na forma de teste das funcionalidades computacionais previstas. Esse tipo de prototipação emprega uma estratégia de prototipação vertical (Nielsen, 2006; Beaudouin-Lafon e Mackay, 2009), dado que privilegia o entendimento de poucas funcionalidades a cada iteração. Nesta etapa, não é utilizado o Formulário de Avaliação, uma vez que seu objetivo é apoiar a avaliação dos testes com usuário, que não ocorrem nesta etapa. No entanto, pode ocorrer de algum acréscimo ou alteração nas Recomendações

Ao término dos testes com todos os cenários de forma satisfatória, dá-se por encerrada esta etapa. É importante que estes testes ocorram antes da implementação do protótipo Hi-fi, uma vez que cada um deles pode envolver alterações no código ou na construção do circuito.

Ao se concluir a implementação do programa e do circuito, é necessário se efetuar a revisão do protótipo Low-fi e do Formulário de Metamensagem a fim de se averiguar se há necessidade de alguma alteração nos mesmos. Caso alguma alteração no protótipo Low-fi esteja relacionada à forma do tangível ou sua interação com o usuário, é necessário refazê-lo - planejar, construir e avaliar - e, para isso, retorna-se à etapa anterior, como indicado no diagrama da Figura 15, a fim de se avaliar os impactos destas alterações no projeto original. 


\subsection{Prototipação do Artefato}

$\mathrm{Na}$ última etapa, o objetivo é o desenvolvimento do protótipo Hi-fi da interface, que integra forma e comportamento. Os designers constroem o tangível com base em protótipos desenvolvidos em etapas anteriores (Low-fi, programação e circuito) e nos requisitos de prototipação atualizadas, como ilustra a Figura 17. O protótipo Hi-fi deve ser mais resistente que os protótipos das etapas anteriores, pois será usado em testes com usuários e, possivelmente, em demonstrações.

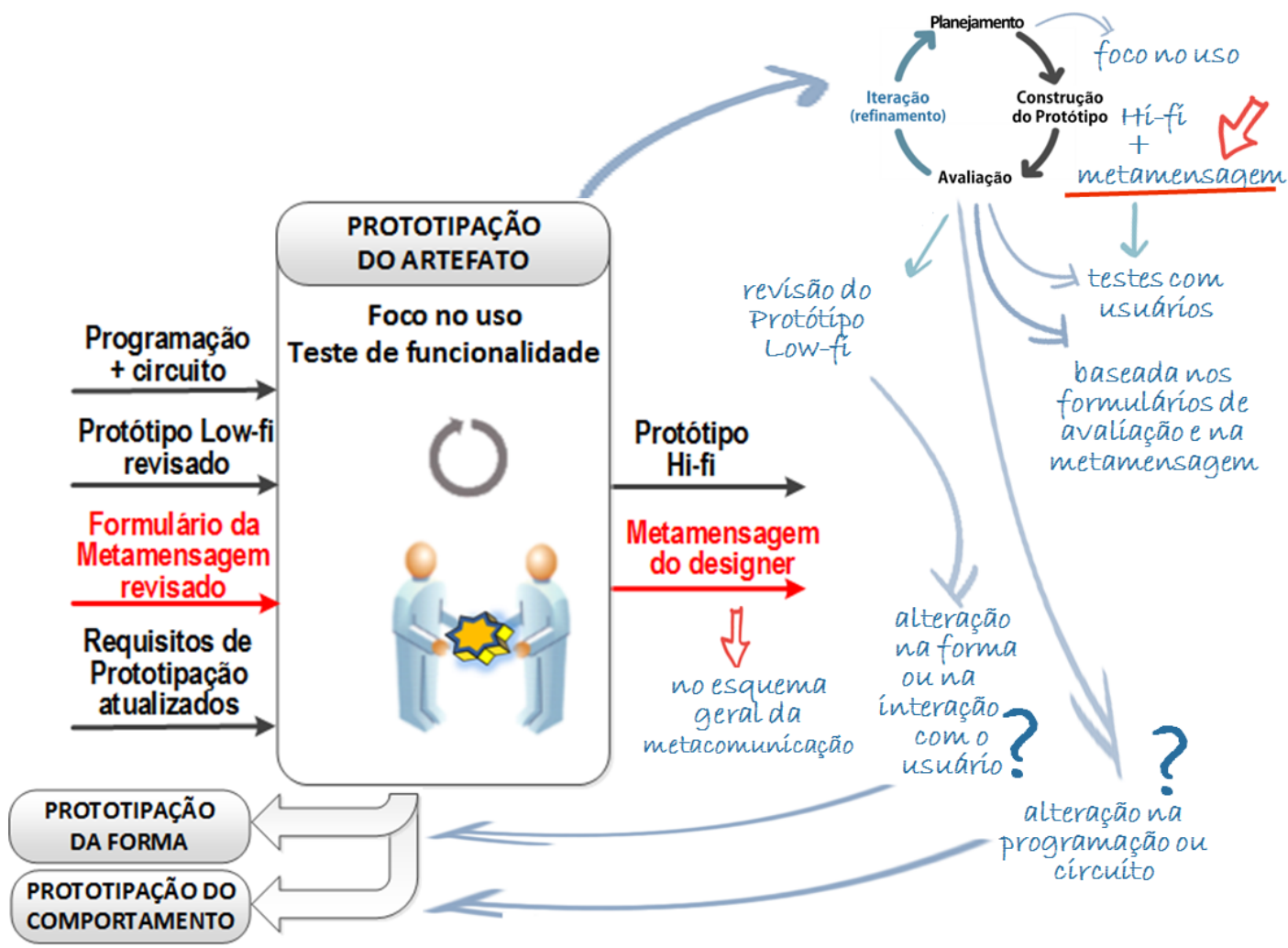

Figura 17: Prototipação do Artefato.

A etapa de planejamento desta fase envolve a seleção de materiais e definição de fases de execução do projeto do protótipo, ou seja: a divisão da tarefa de construção em partes (fases). A construção do protótipo é iterativa e incremental, com fases distintas, cada uma delas contemplando um ou mais aspectos do protótipo previsto. Após planejar a construção do protótipo Hi-fi, os passos a cada iteração são:

1. Selecionar fase do projeto do protótipo para execução;

2. Identificar os elementos do protótipo envolvidos na fase selecionada;

3. Proceder à construção dos elementos da fase selecionada; 
4. Testar todas as funcionalidades disponíveis no protótipo com base nos cenários definidos;

5. Revisar o protótipo e efetuar ajustes em seu projeto ou na execução, caso necessário.

Durante a construção (Figura 18), os testes de implementação de funcionalidades (item 4) são realizados pela própria equipe de projeto. Ao final da fase de construção, quando o protótipo inclui todas as funcionalidades previstas relativas à forma e comportamento -, é iniciada a fase de avaliação do protótipo $\mathrm{Hi}-\mathrm{fi}$, que envolve testes com potenciais usuários.
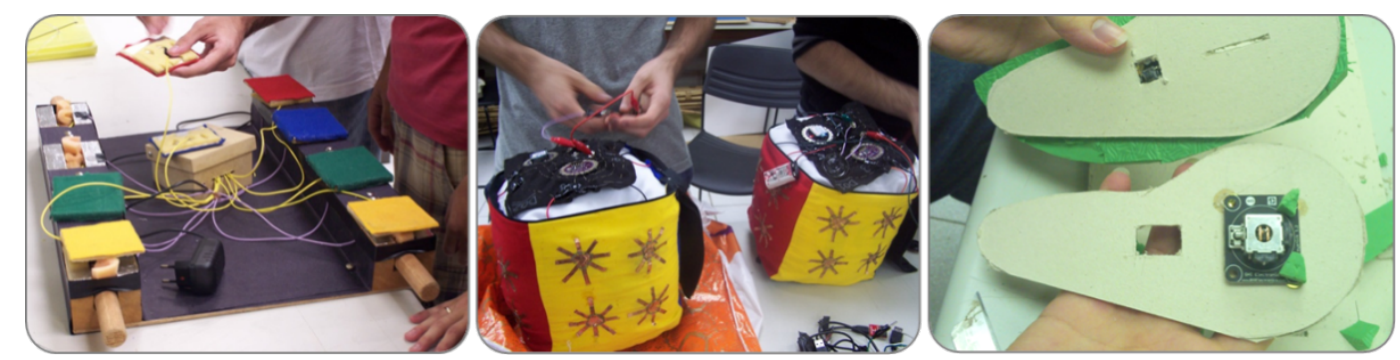

Figura 18: Exemplos de construção do Artefato.

Ao final da fase de construção, os designers preenchem o esquema geral da metacomunicação (p.22), tendo como base o conteúdo do Formulário de Metamensagem preenchido e revisado nas etapas anteriores. Esta metamensagem orienta a observação e análise dos testes com usuário. Cada teste com usuário de fato envolve uma sequência de atividades, detalhadas nas subseções seguintes:

1. Análise inicial do artefato pelo usuário;

2. Teste com Cenário; e

3. Retrospective Think Aloud.

A realização destes testes envolve os seguintes participantes:

- Usuário - participante externo, não pertencente à equipe de projeto; deve atender ao perfil definido nos requisitos;

- Facilitador - participante da equipe que orienta o usuário durante a avaliação, dando as informações necessárias para o teste;

- Observador(es) - participante(s) da equipe responsável(is) pela observação direta das ações do usuário e seu registro no Formulário de Avaliação. 
Nesta etapa o registro do teste através de gravação de vídeo é necessário para a aplicação do Retrospective Think Aloud. O vídeo é também fonte de consulta sobre o teste durante a sua análise.

Ao final do teste, as observações registradas no Formulário de Avaliação e a metamensagem elaborada nesta etapa são utilizados em conjunto na análise do teste, resultando nas conclusões e recomendações da equipe para ajustes no tangível. Não há um número definido para a quantidade de testes com usuário em cada iteração de prototipação. Fica a critério da equipe a decisão sobre a necessidade de realizar mais de um teste para confirmar algum ajuste específico antes da próxima iteração. Dependendo da natureza do ajuste definido pela equipe, pode ser preciso retornar a uma etapa anterior de prototipação, para retomar o enfoque em questões relativas à forma, interação, programação (software) ou circuito (hardware).

Da mesma forma que na Prototipação da Forma, o método não define um número mínimo ou máximo de testes com usuários a serem realizados. A etapa de prototipação deve ser encerrada caso não seja identificado nenhum ajuste na fase de avaliação e a equipe julgue que os testes realizados com usuários foram suficientes, como detalhado na conclusão da Seção 4.2.

Nas subseções seguintes são detalhadas as atividades envolvidas nos testes com usuário.

\subsubsection{Análise Inicial do Artefato pelo Usuário}

A análise do artefato pelo usuário visa identificar como este interpreta as mensagens do designer sem orientações prévias sobre sua função e forma, com base apenas em suas impressões iniciais sobre o tangível. Para efetuar esta análise, o usuário interage com o artefato livremente (sem uma tarefa específica) durante um período de tempo pré-definido, com o objetivo de identificar "o que" faz o artefato. Ao término do período de experimentação livre, o usuário deve relatar resumidamente suas conclusões. Além do relato de suas conclusões ao final, o usuário é orientado a "pensar alto" durante a interação e seus comentários são registrados para posterior análise pela equipe. Enquanto o participante estiver interagindo com o tangível, o(s) observador(es) deve(m) ficar atento(s), procurando identificar possíveis acertos ou dificuldades na comunicação designerusuário mediada pela interface. 
A análise inicial deve ser realizada sem que o usuário tenha tido nenhum tipo de contato anterior com o artefato, de modo a garantir que não haja conhecimento prévio sobre seu uso ou função. Suas impressões são coletadas em duas etapas: $\left(1^{\mathrm{a}}\right)$ com o artefato desligado e $\left(2^{\mathrm{a}}\right)$ com o artefato em funcionamento. A análise do artefato desligado visa enfocar as questões específicas relativas à sua forma.

\subsubsection{Teste com Cenário}

O teste com cenário envolve a execução de tarefas definidas em um Cenário de Interação. Os usuários são observados durante sessões de execução de tarefas e sua interação é registrada através gravação de vídeo e observação direta para posterior análise pelos designers e aplicação do método Restrospective Think Aloud. As observações efetuadas devem ser registradas nos Formulários de Avaliação.

Neste teste, a execução das tarefas é precedida pela familiarização do usuário com o artefato e a leitura do Cenário de Interação. O Cenário de Interação descreve o contexto e as tarefas para a realização dos testes. Ele é elaborado antes do início do teste, com base nos Cenários de Uso descritos nos requisitos de prototipação.

Durante o período de familiarização, o facilitador orienta o usuário sobre o uso da interface e, em seguida, é dado ao usuário alguns minutos para exploração livre da interface pelo usuário. A quantidade de tempo a ser dedicada na orientação sobre o uso e na exploração depende da complexidade da interface. Pode-se ainda optar pela apresentação de um vídeo como forma de orientação.

O Cenário de Interação elaborado para o teste pela equipe de design é entregue ao usuário para leitura e é explicado que ele deve executar as tarefas descritas no cenário. Depois de o usuário ler o cenário, o facilitador pergunta a ele se a tarefa está clara e, se for preciso, explica verbalmente algum ponto que não tenha ficado compreendido. Após obter a confirmação de que está pronto para o início do teste, o usuário inicia a execução das tarefas, que é registrada por meio de gravação de vídeo.

\subsubsection{Restrospective Think Aloud}

Os protocolos Think Aloud (pensar alto) são empregados para que os usuários verbalizem seus pensamentos com relação à execução de uma ou mais 
tarefas durante os testes. A verbalização pode ocorrer durante a execução das tarefas ou, como no Restrospective Think Aloud - RTA - (Haak, de Jong e Schellens, 2003), após sua execução. O objetivo destes protocolos é possibilitar obter informações do próprio usuário sobre suas intenções e seu raciocínio durante a realização das tarefas. São úteis para enfatizar ou explicar dificuldades que o usuário tenha encontrado na realização das tarefas.

Uma das vantagens do RTA é possibilitar que o usuário concentre totalmente sua atenção na execução das tarefas durante o teste, garantindo assim que seu desempenho não seja prejudicado em função da necessidade de narração simultânea. O RTA mostra-se especialmente útil na identificação de dificuldades no teste não percebidas por meio de observação direta e na obtenção de explicações mais detalhadas e sugestões do usuário (Haak, de Jong e Schellens, 2003).

Nesta etapa, o usuário é solicitado a relatar seus pensamentos e ações em retrospectiva, enquanto assiste ao vídeo da realização das suas ações. Seus comentários são registrados por meio de gravação de áudio e, posteriormente, utilizados na análise do teste com usuário.

\subsection{Conclusão do Capítulo}

Este capítulo apresentou o método Prototipação Colaborativa de Tangíveis Baseada na Engenharia Semiótica, que combina as abordagens de prototipação e da Engenharia Semiótica no projeto de interfaces tangíveis. Este método incorpora a um método de prototipação previamente existente a perspectiva da Engenharia Semiótica, cujo foco é a comunicabilidade da interface.

O método proposto é composto por três etapas: Prototipação da Forma, Prototipação do Comportamento e Prototipação do Artefato, cada uma com ênfase em aspectos diferentes do projeto. Utiliza requisitos de prototipação pré-definidos que norteiam o desenvolvimento das etapas de prototipação e contêm: informações sobre contexto, perfil de usuários, características e cenários de uso para a realização dos testes. Dentre as características deste método, destacam-se:

- Resulta em um protótipo de alta fidelidade;

- Resulta em uma metamensagem elaborada pelos designers;

- Possibilita a experimentação com diferentes ideias relacionadas à forma do tangível e à interação com o usuário (prototipação); 
- Inclui atividades de projeto de interface com ênfase na comunicabilidade da interface (Engenharia Semiótica);

- É adequado a diferentes contextos de uso e perfis de equipe de projeto;

- É colaborativo, agregando habilidades e conhecimentos individuais, decorrentes dos diferentes competências, formações e experiências dos designers;

- Independe de conhecimento prévio sobre Engenharia Semiótica.

A Prototipação Colaborativa de Tangíveis Baseada na Engenharia Semiótica agrega os benefícios da experimentação continuada proporcionada pela prototipação e as vantagens do foco na comunicabilidade no desenvolvimento do projeto, desta forma apoiando o projeto de interfaces tangíveis. 


\section{5}

\section{Estudo de Caso}

Este capítulo apresenta o estudo de caso referente à aplicação do método Prototipação Colaborativa de Tangíveis, proposto neste trabalho e detalhado no Capítulo 4, no projeto de uma interface tangível. O capítulo inicia com caracterização do estudo de caso, tratando os elementos referentes à sua classificação, planejamento, coleta e análise dos dados. A segunda parte deste capítulo descreve o desenvolvimento do estudo de caso, com o relato da experiência de projeto da interface tangível, e apresenta o conjunto de dados coletados e sua análise. A terceira parte apresenta as reflexões e comentários acerca dos resultados obtidos e as conclusões deste capítulo.

\subsection{Caracterização do Estudo de Caso}

Yin (1994) afirma que "o estudo de caso é uma inquirição empírica que investiga um fenômeno contemporâneo dentro de um contexto da vida real, quando a fronteira entre o fenômeno e o contexto não é claramente evidente e onde múltiplas fontes de evidência são utilizadas", e que este se caracteriza pela "capacidade de lidar com uma completa variedade de evidências - documentos, artefatos, entrevistas e observações". Ainda de acordo com Yin (1994), a preferência pelo uso do Estudo de Caso deve ser dada quando do estudo de eventos contemporâneos, em situações onde os comportamentos relevantes não podem ser manipulados, mas onde é possível se fazer observações diretas e entrevistas sistemáticas.

Tendo em vista o objetivo deste trabalho (investigar se o método proposto contribui para a aquisição e aplicação de conceitos de Engenharia Semiótica no projeto de interfaces tangíveis), esse estudo de caso se configura como uma pesquisa qualitativo-descritiva, cuja finalidade é a avaliação de um método específico à procura dos efeitos e resultados de sua aplicação (Marconi e Lakatos, 2003). O estudo consiste em uma investigação de pesquisa empírica, centrando 
seu objetivo no entendimento da forma como os designers vivenciam a experiência de aplicação do método proposto, ou seja, o processo (prototipação com Engenharia Semiótica) é mais valorizado que o resultado da aplicação do método em si (o protótipo desenvolvido).

Como ocorre em um Estudo de Caso, os dados foram coletados sob condições de ambiente não controlado, isto é: em contexto real. Para a coleta, foram utilizadas múltiplas fontes de dados: observações diretas, documentos e entrevistas, conforme detalhado na Subseção 5.1.2.

\subsubsection{Seleção do caso}

Foi realizado um estudo de caso único, com múltiplas unidades de análise (Yin, 1994), compostas por cada um dos designers participantes do estudo. O foco de investigação em cada unidade de análise foi a aquisição e aplicação de conceitos de Engenharia Semiótica pelo designer utilizando o método proposto no projeto de uma interface tangível.

Tendo em vista a finalidade do estudo de caso, este se baseou no projeto de um tangível com a aplicação do método proposto por um grupo de quatro designers. Os designers partiram de um conjunto de requisitos de prototipação pré-definidos, com base no qual desenvolveram um protótipo de uma interface tangível aplicando o método Prototipação Colaborativa de Tangíveis Baseada na Engenharia Semiótica, proposto no Capítulo 4. O detalhamento do trabalho desenvolvido pelos designers é apresentado na Seção 5.2.

Os participantes selecionados para o estudo de caso são alunos do Departamento de Informática da Pontifícia Universidade Católica do Rio de Janeiro, membros do laboratório LES/SecondLab, envolvidos com o estudo de Computação Ubíqua e desenvolvimento de Interfaces Tangíveis. O perfil dos participantes é apresentado na Tabela 5.

Tabela 5: Perfil dos participantes.

\begin{tabular}{|c|c|c|c|c|c|}
\hline $\begin{array}{c}\text { Partici } \\
\text { pante }\end{array}$ & Sexo & $\begin{array}{c}\text { Idade } \\
\text { (anos) }\end{array}$ & $\begin{array}{c}\text { Formação } \\
\text { Acadêmica }\end{array}$ & $\begin{array}{c}\text { Conhecimento/ } \\
\text { experiência prévia com } \\
\text { implantação de } \\
\text { sistemas de } \\
\text { computação }\end{array}$ & $\begin{array}{c}\text { Conhecimento/ } \\
\text { experiência prévia com } \\
\text { projeto de interfaces } \\
\text { baseado na Engenharia } \\
\text { Semiótica }\end{array}$ \\
\hline D1 & Fem. & 31 & $\begin{array}{l}\text { Doutorado em } \\
\text { Informática } \\
\text { completo }\end{array}$ & $\begin{array}{l}\text { Conhecimento e } \\
\text { experiência de nível } \\
\text { médio. }\end{array}$ & $\begin{array}{l}\text { Conhecimento e } \\
\text { experiência } \\
\text { acadêmicos de nível } \\
\text { básico. }\end{array}$ \\
\hline
\end{tabular}




\begin{tabular}{|c|l|c|l|l|l|}
\hline $\begin{array}{c}\text { Partici } \\
\text { pante }\end{array}$ & Sexo & $\begin{array}{c}\text { Idade } \\
\text { (anos) }\end{array}$ & \multicolumn{1}{|c|}{$\begin{array}{c}\text { Formação } \\
\text { Acadêmica }\end{array}$} & $\begin{array}{c}\text { Conhecimento/ } \\
\text { experiência prévia com } \\
\text { implantação de } \\
\text { sistemas de } \\
\text { computação }\end{array}$ & $\begin{array}{l}\text { Conhecimento/ } \\
\text { experiência prévia com } \\
\text { projeto de interfaces } \\
\text { baseado na Engenharia } \\
\text { Semiótica }\end{array}$ \\
\hline D2 & Mas. & 33 & $\begin{array}{l}\text { Doutorado em } \\
\text { Informática } \\
\text { incompleto }\end{array}$ & $\begin{array}{l}\text { Conhecimento e } \\
\text { experiência de nível } \\
\text { avançado. }\end{array}$ & Nenhum. \\
\hline D3 & Mas. & 32 & $\begin{array}{l}\text { Doutorado em } \\
\text { Informática } \\
\text { incompleto }\end{array}$ & $\begin{array}{l}\text { Conhecimento e } \\
\text { experiência de nível } \\
\text { avançado. }\end{array}$ & $\begin{array}{l}\text { Conhecimento } \\
\text { acadêmico de nível } \\
\text { básico. Nenhuma } \\
\text { experiência. }\end{array}$ \\
\hline D4 & Mas. & 21 & $\begin{array}{l}\text { Graduação em } \\
\text { Engenharia da } \\
\text { Computação } \\
\text { incompleta }\left(4^{\circ}\right. \\
\text { ano) }\end{array}$ & $\begin{array}{l}\text { Conhecimento e } \\
\text { experiência } \\
\text { estritamente } \\
\text { acadêmicos de nível } \\
\text { básico. }\end{array}$ & Nenhum. \\
\hline
\end{tabular}

Os participantes foram selecionados com base nos seguintes pré-requisitos:

- O participante deve possuir conhecimento prático e teórico sobre o desenvolvimento de interfaces de usuários;

- O participante deve possuir conhecimento prático e teórico no uso de uma ou mais plataformas de prototipação para desenvolvimento de interfaces tangíveis (Arduino, MS Gadgeteer, etc.);

- O participante deve possuir experiência no desenvolvimento de interfaces tangíveis com o uso da versão anterior do método Prototipação Colaborativa de Tangíveis, sem a construção da metamensagem do designer; e

- O participante não deve ter experiência prévia com a aplicação do método como atualmente proposto.

Os pré-requisitos (a) e (b) tiveram por objetivo garantir um conjunto mínimo de conhecimento prático e teórico necessário à aplicação do método fora do contexto de aprendizado (Seção 4.5). Os itens (c) e (d) foram incluídos especificamente visando obter dados relacionados especificamente à inclusão da dos conceitos de Engenharia Semiótica como parte do método proposto, partindo da existência de uma experiência prévia do participante com o método de prototipação sem a incorporação da Engenharia Semiótica (c), mas sem experiência anterior com o método aqui proposto. 


\subsubsection{Coleta e análise dos dados}

Tendo como objetivo de estudo a investigação da contribuição do método proposto para a aquisição e a aplicação de conceitos de Engenharia Semiótica, é necessário definir inicialmente: (i) que conceitos serão enfocados, (ii) quais manifestações serão consideradas indícios da aquisição e aplicação destes conceitos pelos participantes, e, consequentemente, serão focos de análise da pesquisa, e (iii) os parâmetros a serem utilizados como base para a análise:

i. Serão considerados no escopo desse estudo os seguintes conceitos de Engenharia Semiótica:

a. O projeto de interfaces deve ter como foco principal a comunicação designers-usuários mediada pela interface;

b. O artefato comunica uma mensagem do designer para os usuários sobre o que o faz, como pode ser utilizado e por quê.

c. A interface comunica ao usuário, durante a interação, a metamensagem do designer sobre o que sabem sobre o usuário, que problemas a interface pode resolver e como interagir com ela.

ii. São considerados indícios da aquisição e aplicação de conceitos pelos participantes neste estudo e focos de análise da pesquisa:

a. Exames de questões do projeto da interface relacionadas a conceitos de Engenharia Semiótica; e

b. O emprego correto de conceitos de Engenharia Semiótica.

iii. Os parâmetros de análise estão relacionados aos conteúdos e foco de análise, como detalhado na Tabela 6.

Tabela 6: Parâmetros de análise.

\begin{tabular}{|l|l|l|}
\hline \multirow{2}{*}{ Conteúdo } & \multicolumn{2}{|c|}{ Foco de Análise } \\
\cline { 2 - 3 } & $\begin{array}{l}\text { a. Exame de questões do } \\
\text { projeto }\end{array}$ & $\begin{array}{l}\text { b. Emprego correto de } \\
\text { conceito }\end{array}$ \\
\hline $\begin{array}{l}\text { a. Foco na } \\
\text { comunicação } \\
\text { designers- } \\
\text { usuários }\end{array}$ & $\begin{array}{l}\text { Parcela da comunicação (oral } \\
\text { ou escrita) dedicada ao exame } \\
\text { de questões de projeto } \\
\text { relacionadas à } \\
\text { comunicabilidade da interface. }\end{array}$ & $\begin{array}{l}\text { Ocorrência de referência direta } \\
\text { ou indireta à mensagem ou } \\
\text { metamensagem com emprego } \\
\text { correto. }\end{array}$ \\
\hline b. Mensagem & \multicolumn{1}{|c|}{$\begin{array}{l}\text { Ocorrência de referência direta } \\
\text { ou indireta à mensagem com } \\
\text { emprego correto. }\end{array}$} \\
\hline
\end{tabular}




\begin{tabular}{|l|l|l|}
\hline \multirow{2}{*}{ Conteúdo } & \multicolumn{2}{|c|}{ Foco de Análise } \\
\cline { 2 - 3 } & $\begin{array}{l}\text { a. Exame de questões do } \\
\text { projeto }\end{array}$ & $\begin{array}{l}\text { b. Emprego correto de } \\
\text { conceito }\end{array}$ \\
\hline c. Metamensagem & \multicolumn{1}{|c|}{$-\begin{array}{l}\text { Ocorrência de referência direta } \\
\text { ou indireta à metamensagem } \\
\text { com emprego correto. }\end{array}$} \\
\hline
\end{tabular}

A pesquisa descritiva "observa, registra, analisa, e correlaciona fatos e fenômenos sem manipulá-los" (Rudio, 1999). Como ocorre em um Estudo de Caso, os dados foram coletados em contexto real. Na presente pesquisa, os dados coletados para o estudo se originaram a partir de três fontes:

1. Observação direta;

2. Documentos produzidos pelos participantes; e

3. Entrevistas presenciais com os participantes.

A observação foi individual (observador único), aberta (observador visível) e não-participante (o observador não se envolve nas atividades ${ }^{23}$ ). A observação foi sistemática (Marconi e Lakatos, 2003), tendo como foco a construção da mensagem do designer e sua relação com o processo de construção do tangível. A observação foi realizada durante os encontros de trabalho do grupo, que ocorreram no laboratório LES/SecondLab da PUC-Rio, e documentada por meio de registro escrito, e, em algumas ocasiões, gravações de áudio ou vídeo.

Os documentos produzidos utilizados como fonte de pesquisa foram os Formulários de Avaliação preenchidos pelos participantes. Estes formulários contêm o registro dos pontos destacados pelos designers na realização dos testes com usuários e que fomentaram as discussões envolvendo a avaliação do tangível.

Para concluir a coleta de dados, foram conduzidas entrevistas semiestruturadas individuais, realizadas presencialmente com cada um dos participantes após a conclusão da aplicação do método. As entrevistas enfocaram dois aspectos principais: o projeto do tangível e a aplicação do método proposto. Um roteiro de itens abertos (e não de perguntas prontas) foi utilizado como base para a realização das entrevistas, com o propósito de proporcionar uma comunicação mais natural entre entrevistado e entrevistador (Nicolaci-da-Costa et

\footnotetext{
${ }^{23}$ A participação da pesquisadora durante o desenvolvimento do tangível se limitou a sua atuação como facilitadora, fornecendo aos participantes orientações e recursos (formulários, templates, insumos, etc.) necessários para a aplicação do método e construção do protótipo.
} 
al., 2004). Todos os itens previstos no roteiro, relacionados a seguir, foram abordados nas entrevistas:

- PARTE 1: Projeto do tangível

- intenção dos designers;

- percepção do público-alvo;

- foco do design;

- intenção vs realização;

- pontos fortes do projeto; e

- sugestões de melhorias.

\section{- PARTE 2: Aplicação do método}

- desenvolvimento das três etapas de prototipação propostas no método;

- trabalho em grupo;

- versão anterior do método de prototipação vs versão atual (com construção da metamensagem);

○ uso dos formulários;

○ modo de avaliações;

○ benefícios percebidos com a inclusão da construção da metamensagem na prototipação;

- dúvidas e dificuldades na utilização do método; e

- sugestões para a melhoria do método.

$\mathrm{Na}$ análise dos dados provenientes da observação, documentos e entrevistas, buscou-se identificar subsídios que possibilitassem estabelecer recorrências ou singularidades relacionadas à aquisição e aplicação de conceitos de Engenharia Semiótica. A validade interna no estudo de caso foi tratada buscando-se o estabelecimento de fortes conexões entre os dados de diferentes fontes através da triangulação (Yin, 1984). Neste estudo, a triangulação das fontes de dados ocorre na conclusão das análises para cada um dos focos definidos.

A fim de auxiliar no refinamento dos procedimentos de coleta e registro de dados, foi realizado um estudo piloto (Yin, 1984), no mesmo local e em condições similares às deste estudo de caso.

\subsection{Desenvolvimento do Estudo de Caso}

Para este estudo, foi proposto ao grupo participante que desenvolvesse um projeto de interface tangível para um convite de uma festa de aniversário. A 
pesquisadora que conduziu este estudo atuou como facilitadora (páginas 46 e 48), orientando o grupo na aplicação do método.

Antes de iniciar a prototipação, os designers foram instruídos acerca das etapas de trabalho e sobre alguns conceitos básicos de Engenharia Semiótica (Seção 4.1.2). Em seguida, receberam para o início do trabalho o seguinte conjunto de pré-requisitos de prototipação, definidos especificamente para este estudo:

\section{- Contexto e Perfil de usuário:}

- Convite para festa de comemoração de aniversário a ser enviado para colegas e amigos.

- Os usuários são os convidados da festa, destinatários dos convites.

- Os usuários têm idade e sexo variados, entre 18 e 40 anos. Têm preferência por convites interativos, alegres e que surpreendam porque os consideram mais divertidos.

- Critérios:

- Ser lúdico e interativo.

- Ser amigável para iniciantes em tecnologia.

- Diretrizes:

- O convite deverá informar o usuário sobre o evento a partir de sua interação com o tangível.

- Cada informação será dada a partir de uma interação distinta.

- As informações a serem disponibilizadas são:

○ Tipo de evento: Festa de aniversário

- Nome da aniversariante: Denise

○ Local: Rua Dr. Odilon Beauclair, n.73, Camboinhas, Niterói

- Data: 17 de novembro de 2014

○ Horário: $21 \mathrm{~h}$.

- O convite também será utilizado para que o convidado confirme ou não sua participação no evento.

\section{- Cenários de Uso:}

- O usuário deve identificar qual o evento, seu local, data e horário interagindo com o convite. Depois, o usuário deverá informar se irá ou não participar do evento. 
Na etapa inicial - Prototipação da Forma -, os designers construíram um protótipo Low-fi em três dimensões. Na opinião o designer D3, “ajuda muito você começar sem embarcar nenhuma tecnologia ou pensar em código, ou em qual o equipamento você vai usar".

O material utilizado para a construção do protótipo Low-fi foi o papel, visando manter a forma do convite o mais semelhante possível aos convites de festa em forma de cartão, comumente utilizados. Quando o cartão é aberto, leds são ligados e uma música de fundo selecionada pelo grupo é tocada. De acordo com relato do designer D4, estas ideias tinham por objetivo "dar uma ideia de festa". A música de fundo escolhida foi "Little Bad Girl" do cantor David Guetta, considerada pelo grupo uma música associada à diversão adulta.

No Low-fi, a parte interna do convite contém a imagem da personagem Mulher-Gato (das histórias de super-herói) em formato pop-up e um fundo que contém imagens de balões, indicando que se trata de uma festa. Os leds ligados estão posicionados dentro desses balões. A personagem Mulher-Gato utiliza uma máscara que é removida quando é deslizada para a lateral, revelando o rosto da personagem e o nome da aniversariante. Segundo o designer D2, "queríamos que a pessoa entendesse que era uma festa à fantasia e por isso colocamos isso ( $a$ máscara) no design". Ao remover a máscara, leds contidos nos olhos da personagem piscam e a música de fundo é substituída pelo popular "Parabéns pra você", para relacionar o convite a aniversário. Este é repetido duas vezes e depois sucedido pela música de fundo.

De acordo com interface proposta pelo grupo nesta primeira etapa de prototipação, para que o usuário obtenha as informações sobre o evento e confirme sua participação, ele deve (Figura 19):

1 Remover a máscara da personagem escolhida e descobrir o nome da aniversariante; a máscara é removida por um mecanismo de deslizamento quando a tira é puxada; na ponta dessa tira encontram-se o ícone 4 e texto "Puxe"; sobre os olhos da personagem encontra-se o nome da aniversariante, revelado apenas quando a máscara é puxada; 
2 Deslizar a tira de papel posicionada na lateral esquerda o cartão, que contém um QR Code ${ }^{24}$ que remete a um link para abertura de aplicativo de pesquisa e visualização de mapas, desta forma indicando a localização do evento; na ponta da tira encontram-se o ícone 4 e o texto "Puxe";

3 Encher o balão inflável de borracha contido no interior do cartão, que tem um QR Code com link para a agenda eletrônica do usuário, que informa a data e horário do evento (usuário opta por incluir ou não o evento em sua agenda); na ponta da tira encontram-se o texto "Me encha";

4 Selecionar um dos QR Codes disponíveis para confirmação de presença no evento que contêm links para páginas do Facebook especialmente criadas para controle de frequência neste evento; a pergunta "Vai?" está posicionada entre os códigos e logo acima das respostas correspondentes, representadas por ícones: $\boldsymbol{\vartheta}$ para resposta positiva e $\mathbf{X}$ para resposta negativa.

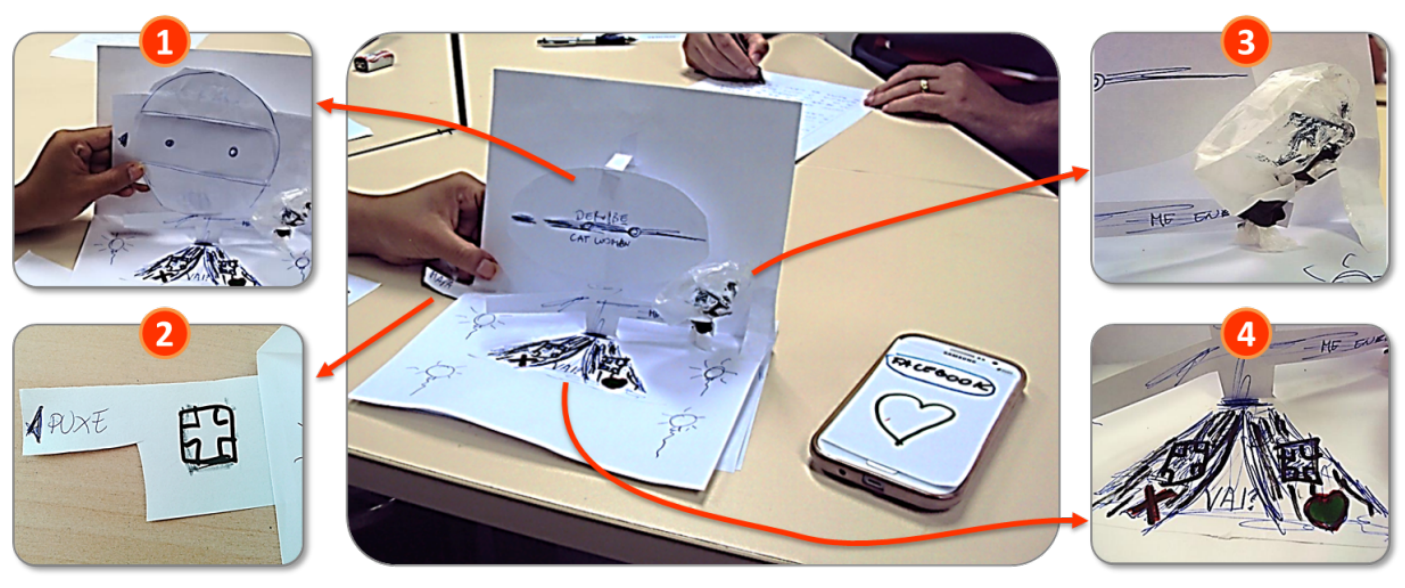

Figura 19: Protótipo Low-fi.

A opção pelo uso de QR Code se deve à intenção do grupo de possibilitar (mas não obrigar) o uso do convite não só como fonte de informação, mas também como auxílio ao usuário no planejamento de sua participação no evento por meio do uso de aplicativos disponíveis para dispositivos móveis (agenda de

${ }^{24}$ O QR Code consiste de um código gráfico 2D que contém informações como textos, links para páginas da internet ou números de telefone. Este código é lido por meio de equipamentos específicos para este tipo de código ou de aplicativos instalados em dispositivos móveis. 
compromissos, visualização de mapas, e rede social). Isto teve por objetivo fazer com que a interação "não ficasse só no cartão, mas que através dos QR Codes você pudesse ter o convite não só no físico como no virtual", segundo a designer D1. Este item não consta como um dos requisitos de prototipação, bem como o tipo de evento (festa à fantasia) e a temática da festa (super-heróis). Estes foram itens incluídos pelo grupo, resultantes do processo de ideação do tangível. Esta extrapolação dos requisitos iniciais é prevista no método de Prototipação Colaborativa de Tangíveis Baseada na Engenharia Semiótica em alguns contextos, como ocorre neste caso.

O Formulário de Metamensagem preenchido pelo grupo durante a construção do protótipo Low-fi (Apêndice B) foi utilizado como subsídio para a fase de avaliação nesta etapa. A avaliação baseou-se na realização de testes com usuário, conforme proposto no método (Seção 4.1). O grupo utilizou o Formulário de Avaliação (Apêndice C) para o registro das observações e conclusões do grupo, que "ajudou a manter as ideias originais do projeto até a construção final do protótipo... (e deste modo) facilita num processo de documentação“ (D4).

O número de testes envolvidos na fase de avaliação não é especificado no método proposto, ficando esta decisão a cargo do grupo. Neste caso, o teste do protótipo Low-fi foi realizado com apenas um usuário. Com base nos resultados desta avaliação, o grupo acordou em não realizar modificações no protótipo e optou por encerrar a fase de avaliação dessa etapa.

$\mathrm{Na}$ etapa de Prototipação do Comportamento, foram desenvolvidos o circuito, a programação e os QR Codes a serem utilizados na construção do tangível na etapa seguinte. O grupo optou pela plataforma Arduino ${ }^{25}$ para a implementação, especificamente os componentes da família Lilypad, por serem de pouca espessura e, portanto, adequados à construção de um tangível no formato de cartão, como proposto no protótipo Low-fi. Nesta etapa, os testes foram relativos às funcionalidades implementadas e não envolveram usuários.

A etapa final, de Prototipação do Artefato, iniciou-se com a seleção dos materiais e imagens a serem empregados na construção do tangível pelos designers. A opção pelo papel pluma ${ }^{26}$ como material básico se deveu à

\footnotetext{
25 Arduino é uma plataforma de prototipação eletrônica de software e hardware opensource (http://arduino.cc).

${ }^{26}$ Placa de isopor laminado coberto com papel de alta gramatura em ambas os lados.
} 
necessidade de embutir no convite os componentes do circuito (microcontrolador, leds, bateria,...), como mostra a Figura 20, e assegurar suficiente durabilidade para a realização dos testes com usuário nessa etapa.
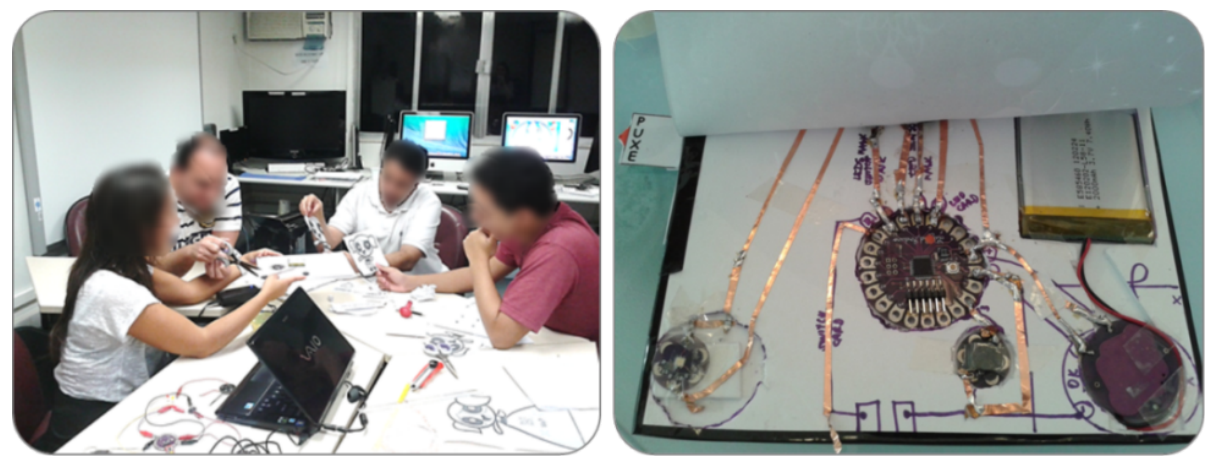

Figura 20: Prototipação do Artefato.

Durante a construção do tangível, algumas ideias propostas na etapa inicial de prototipação para o protótipo Low-fi foram modificadas:

- Em função da solução tecnológica adotada para detectar a remoção da máscara da personagem, optou-se pela abertura da máscara ao invés do mecanismo de deslizamento inicialmente proposto; o nome da aniversariante foi posicionado no verso da máscara;

- Foi incluído o texto "Endereço" na tira de papel deslizante localizada na lateral do cartão, sobre o QR Code para abertura de aplicativo de mapas;

- A ideia inicial de imprimir o QR Code no balão inflável de borracha não pôde ser executada devido à falta de tecnologia disponível para a impressão nesse tipo de material com a precisão necessária para a leitura do código; por este motivo, o QR Code foi impresso em papel e colado na superfície do balão, não sendo mais necessário que este seja inflado para a leitura do código; a mensagem "Me Encha" foi removida;

- Ao invés de utilizar dois códigos para a confirmação de presença, o usuário usa um único QR Code com link para uma página do Facebook que contém uma opção para o usuário confirmar sua participação;

- Devido a dificuldades no uso do componente para leitura de arquivos de áudio, optou-se pela utilização de speaker Arduino (Lilypad Buzzer) e o uso de programação para reproduzir a música selecionada, resultando em uma composição musical baseada na produção de uma única nota de cada vez, sem acordes ou percussão; devido à necessidade de 
programação das notas e pausas neste tipo de solução, o grupo decidiu implementar apenas um trecho da música e repeti-lo indefinidamente;

- Durante a construção da parte interna do cartão, o grupo optou por utilizar imagens prontas, disponíveis na internet; por necessitarem de uma imagem de personagem com uma cabeça grande na qual pudesse ser colocar os leds (nos olhos) e a máscara, a personagem Mulher-Gato, inicialmente proposta, foi substituída pela personagem Lindinha, uma das três heroínas do desenho animado infantil "Meninas SuperPoderosas"; a imagem de fundo, que no protótipo Low-fi continha balões, foi substituída por uma imagem com fundo preto e estrelas, nas quais foram posicionados três leds que são ligados quando o convite é aberto;

- Foram incluídas instruções para uso do QR Code no verso do cartão com o objetivo de orientar usuários que não conheçam ou não saibam utilizar este tipo de código.

Algumas destas modificações podem ser observadas na versão final do convite, apresentada na Figura 21.

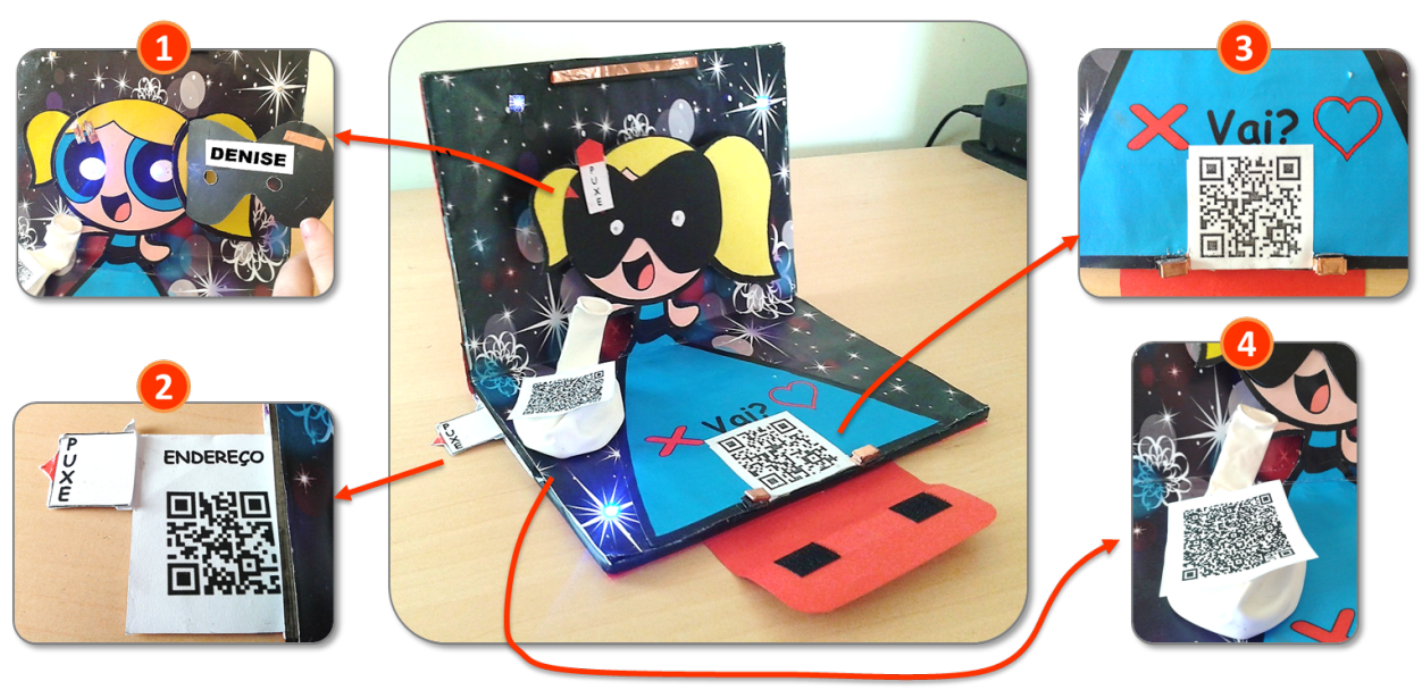

Figura 21: Versão final do protótipo Hi-fi.

A Metamensagem do Designer foi elaborada pela equipe quando da conclusão da construção do protótipo, antes da realização dos testes. Na opinião do designer D4: "quando todo mundo senta pra fazer a metamensagem e acorda aquela metamensagem, traz o grupo de novo pra uma ideia comum". O processo de construção da metamensagem se inicia na primeira etapa de prototipação, com o preenchimento do Formulário de Metamensagem. Este formulário é revisado a 
cada iteração de prototipação nesta etapa inicial, considerando os resultados da avaliação do tangível por meio de testes com usuário, e na conclusão da etapa de Prototipação do Comportamento. ${ }^{27}$ A versão final da mensagem do designer, elaborada pela equipe com base no conteúdo do formulário revisado, foi:

\section{METAMENSAGEM DO DESIGNER}

Esse cartão interativo é como eu entendo que você, convidado da festa da Denise, gostaria de ser convidado para este evento, já que gosta de convites alegres, surpreendentes e divertidos. Nessa festa, você deve ir fantasiado, como sugere o visual do convite, que segue a temática de super-heróis, com a heroína Lindinha das Meninas Super-Poderosas. Ao abrir o cartão, você ouve a música "I Gotta Feeling", que combina com a ocasião. Ao desmascarar a heroína, você descobre o nome da anfitriã da festa, enquanto ouve a música "Parabéns pra você", que indica o tipo de evento. No convite, você encontra QR Codes localizados na lateral do cartão e no balão de encher, que contêm informações sobre endereço, data e horário da festa. Para acessar estas informações, você deve utilizar o seu smartphone e um aplicativo de leitura deste tipo de código. Caso você não saiba utilizar QR Codes, consulte as instruções contidas no verso do cartão. Além de obter informações, ao usar este aplicativo você poderá optar por incluir este evento na sua agenda de compromissos e marcar o local da festa no seu aplicativo de mapas (no Google Maps, por exemplo). Adicionando esse compromisso à sua agenda, é possível utilizar os avisos do seu sistema de agenda para que você seja lembrado sobre o evento. Além de indicar a localização da festa no mapa, o QR Code que contém o endereço, posicionado na lateral do cartão, possibilita que você trace uma rota do seu endereço até o local da festa e utilize (caso tenha) o sistema de navegação do seu smartphone para orientar-se quando estiver se dirigindo para a festa. Um outro QR Code, localizado na saia da Lindinha, deve ser utilizado para você confirmar sua presença. Ele irá remetê-lo a uma página do Facebook específica para esta finalidade. Esperamos que a interatividade do cartão o motive a ir à festa e que o uso dos QR Codes o ajudem a se organizar para lembrar o dia/hora, chegar ao local e confirmar (ou não) sua presença na festa.

Nesta última etapa, foram realizados quatro testes com usuários envolvendo o uso do convite. Todos os usuários cumpriram com sucesso as tarefas propostas no seguinte Cenário de Interação:

27 A única alteração na metamensagem do designer ocorrida após as iterações de prototipação resultou da mudança da música de fundo, que inicialmente era "Little Bad Girl". 
Você recebeu um convite de uma amiga para um evento. Descubra quem o/a convidou, para que evento, e onde e quando vai ser. Para concluir, confirme sua presença.

Os designers foram orientados a utilizar a metamensagem elaborada pelo grupo como base para a avaliação e o Formulário de Avaliação (Apêndice C) para o registro de suas observações e conclusões em cada teste. Na opinião de D3, neste tipo de avaliação, “os formulários ajudam na documentação do projeto, das etapas, e nos logs das propostas; se a gente mudou, não mudou, se a gente acompanhou o que a gente escreveu no início... ajuda como um guia de referência do que a gente foi pensando e o que a gente foi mudando depois" e "a metamensagem ajuda como um guia pra você estar sempre relembrando o que você quis passar pro usuário e na hora do teste... funciona como um guideline e dá pra ver bem claro as que a gente conseguiu passar e as mensagens que a gente não conseguiu",

A cada teste, foram definidas as alterações a serem implementadas na versão seguinte do protótipo, resultando em uma iteração de prototipação por teste. As alterações realizadas são apresentadas na Tabela 7. A possibilidade de iteração proporcionada pela prototipação é um dos pontos fortes do método, de acordo com D3: “eu acho que o método é bom porque é um ciclo constante: você vai fazer, vai testar e vai ver o que você tentou passar, mas não passou e refazer; fazer, testar e refazer, até você fazer uma coisa que funcione".

Tabela 7: Testes com usuários durante a etapa de Prototipação do Artefato.

\begin{tabular}{|c|c|c|}
\hline Usuário & Conclusões do grupo & Alterações \\
\hline $\begin{array}{c}\text { U1 } \\
\text { Sexo masculino, } 30 \\
\text { anos, com } \\
\text { conhecimento prévio } \\
\text { sobre uso do QR Code, } \\
\text { utiliza os aplicativos de } \\
\text { dispositivo móvel } \\
\text { envolvidos no teste. }\end{array}$ & $\begin{array}{l}\text { O usuário achou que se tratava } \\
\text { de um convite para uma festa } \\
\text { infantil por causa da } \\
\text { personagem Lindinha e por } \\
\text { não ter identificado a música } \\
\text { selecionada pelo grupo ("Little } \\
\text { Bad Girl"), que deveria ser } \\
\text { associada a uma festa adulta. } \\
\text { O usuário considerou a música } \\
\text { desagradável (som agudo) e } \\
\text { repetitiva. }\end{array}$ & $\begin{array}{l}\text { Alterar a música para uma } \\
\text { mais conhecida ("I Gotta } \\
\text { Feeling" do conjunto Black } \\
\text { Eyed Peas), mantendo a } \\
\text { personagem. } \\
\text { A música programada deverá } \\
\text { ter uma duração maior para } \\
\text { diminuir o número de } \\
\text { repetições. } \\
\text { Atualizar a metamensagem. }\end{array}$ \\
\hline
\end{tabular}




\begin{tabular}{|c|c|c|}
\hline Usuário & Conclusões do grupo & Alterações \\
\hline & $\begin{array}{l}\text { Não entendeu que se tratava de } \\
\text { uma festa à fantasia. }\end{array}$ & $\begin{array}{l}\text { Incluir informações sobre o } \\
\text { tipo de festa no título do } \\
\text { evento no QR Code } \\
\text { correspondente à agenda e na } \\
\text { página do Facebook de } \\
\text { "Festa da Denise" para } \\
\text { "Festa à Fantasia da Denise", } \\
\text { fornecendo uma informação } \\
\text { direta sobre a natureza da } \\
\text { festa. }\end{array}$ \\
\hline & $\begin{array}{l}\text { Já conhecia QR Codes. Não } \\
\text { teve dificuldade com o uso da } \\
\text { tecnologia. }\end{array}$ & $\begin{array}{l}\text { Manter os QR Codes. } \\
\text { Realizar o próximo teste com } \\
\text { um usuário que não conheça } \\
\text { essa tecnologia. }\end{array}$ \\
\hline \multirow[t]{2}{*}{$\begin{array}{c}\text { U2 } \\
\text { Sexo feminino, } 28 \\
\text { anos, sem } \\
\text { conhecimento prévio } \\
\text { sobre uso de QR Code, } \\
\text { não utiliza os } \\
\text { aplicativos de } \\
\text { dispositivo móvel } \\
\text { envolvidos no teste. }\end{array}$} & $\begin{array}{l}\text { Como a usuária não conhecia o } \\
\text { QR Code, teve dificuldade no } \\
\text { uso dessa tecnologia. As } \\
\text { instruções contidas no verso } \\
\text { do convite não foram } \\
\text { suficientes para que ela } \\
\text { utilizasse este recurso. }\end{array}$ & $\begin{array}{l}\text { Substituir as instruções do } \\
\text { verso por instruções mais } \\
\text { detalhadas. } \\
\text { Realizar o próximo teste com } \\
\text { um usuário que não conheça } \\
\text { essa tecnologia. }\end{array}$ \\
\hline & $\begin{array}{l}\text { Não achou o convite infantil. } \\
\text { Reconheceu a música, mas } \\
\text { comentou que não gostou do } \\
\text { tipo de áudio. }\end{array}$ & $\begin{array}{l}\text { Manter a música atual. } \\
\text { O uso do speaker Arduino } \\
\text { será mantido, não havendo } \\
\text { solução para o problema do } \\
\text { tipo de áudio para este } \\
\text { estudo. }\end{array}$ \\
\hline \multirow[t]{2}{*}{$\begin{array}{c}\text { U3 } \\
\text { Sexo feminino, } 35 \\
\text { anos, sem } \\
\text { conhecimento prévio } \\
\text { sobre uso do QR Code, } \\
\text { utiliza os aplicativos de } \\
\text { dispositivo móvel } \\
\text { envolvidos no teste. }\end{array}$} & $\begin{array}{l}\text { A usuária não conhecia o QR } \\
\text { Code, mas conseguiu utilizar a } \\
\text { tecnologia com o auxílio das } \\
\text { orientações contidas no verso } \\
\text { sem demonstrar dificuldade. } \\
\text { No entanto, levou algum } \\
\text { tempo lendo as orientações. }\end{array}$ & $\begin{array}{l}\text { Alterar as instruções contidas } \\
\text { no verso, tornando-as uma } \\
\text { sequência de passos com } \\
\text { ilustrações. }\end{array}$ \\
\hline & $\begin{array}{l}\text { Não achou o convite infantil. } \\
\text { Reconheceu a música, mas } \\
\text { comentou que a achou } \\
\text { "irritante". }\end{array}$ & $\begin{array}{l}\text { Manter a música atual e o } \\
\text { uso do speaker Arduino. }\end{array}$ \\
\hline $\begin{array}{c}\mathrm{U} 4 \\
\text { Usuário do sexo } \\
\text { masculino, } 36 \text { anos, } \\
\text { com conhecimento } \\
\text { prévio sobre uso do QR } \\
\text { Code, utiliza os } \\
\text { aplicativos de } \\
\text { dispositivo móvel } \\
\text { envolvidos no teste. }\end{array}$ & $\begin{array}{l}\text { Já conhecia QR Codes e } \\
\text { utilizou a tecnologia sem } \\
\text { demonstrar dificuldade. } \\
\text { Não achou o convite infantil. } \\
\text { Reconheceu a música, mas } \\
\text { comentou que achou de baixa } \\
\text { qualidade. }\end{array}$ & $\begin{array}{l}\text { Manter a música atual e o } \\
\text { uso do speaker Arduino. } \\
\text { Encerrar os testes com } \\
\text { usuário. }\end{array}$ \\
\hline
\end{tabular}

As alterações efetuadas pelo grupo resultaram na versão final do protótipo, apresentada na Figura 21. 


\subsection{Resultados}

Os dados coletados foram selecionados, codificados e tabulados em função dos focos de análise de pesquisa considerados neste estudo, descritos na Tabela 6. A seleção dos dados foi efetuada por meio de:

- Observação direta - análise dos signos linguísticos que integram as falas dos participantes ocorridas durante os encontros de trabalho (comunicação oral);

- Documentos produzidos - análise dos signos linguísticos que integram os textos (comunicação escrita) contidos nos Formulários de Avaliação preenchidos pelos participantes durante os testes com usuários nas etapas de Prototipação da Forma e Prototipação do Artefato; e

- Entrevistas - análise dos signos linguísticos que integram as falas dos entrevistados (comunicação oral); dependendo do foco, foram consideradas ambas as partes da entrevista (1 e 2) ou apenas uma delas.

A codificação e tabulação dos dados variaram em função dos focos de análise e parâmetros adotados. As subseções a seguir apresentam a codificação e tabulação dos dados e resultados obtidos para cada foco definido.

\subsubsection{Exame de questões de projeto relacionadas à comunicabilidade da interface}

A investigação sobre o exame de questões de projeto relacionadas à comunicabilidade da interface pelos participantes tem por objetivo obter indícios quanto à aquisição e aplicação dos conceitos de Engenharia Semiótica no projeto de interfaces com foco principal na comunicação designers-usuários mediada pelo sistema. O parâmetro para análise neste caso é a parcela da comunicação (oral ou escrita) dedicada espontaneamente ao exame de questões de projeto relacionadas à comunicabilidade da interface. Quanto maior este percentual, mais tempo a equipe de design dedicou à aplicação destes conceitos no projeto da interface.

A parcela da comunicação dedicada a estas questões é calculada em termos percentuais, a partir da identificação de trechos de comunicação que indiquem relação com o projeto da interface sob a perspectiva de comunicabilidade. A identificação do tema central em cada trecho de comunicação possibilita sua classificação em blocos temáticos com durações de tempo (oral) ou quantidade de frases (escrita) bem definidas. A parcela de tempo/quantidade de frases é 
calculada somando-se a duração/número de frases relacionadas ao tema em questão e dividindo este valor pela a duração total/número total de frases.

Vale ressaltar que no caso da observação direta e documentação os resultados são referentes à comunicação do grupo, uma vez que tanto as discussões como o preenchimento dos formulários foram realizadas em grupo. Como não há interferência do pesquisador nestas atividades, quaisquer exames de questões do projeto relacionadas à comunicabilidade da interface por parte do grupo foram espontâneos. No caso da documentação, tendo em vista que os campos do formulário - "Observações", "Comentários do usuário", "Modificações indicadas" e "Recomendações relativas ao protótipo para iterações ou etapas seguintes" - estão relacionados ao tipo de registro e não fazem referência a conceitos de Engenharia Semiótica, quaisquer registros efetuados pelo grupo relacionados à comunicabilidade foram também espontâneos.

Nota-se com base nos resultados apresentados na Tabela 8 que as maiores parcelas de comunicação dedicadas pelo grupo ao exame de questões estão relacionadas à comunicabilidade da interface concentram-se no início, durante o processo de ideação do tangível (planejamento/Forma), e ao final, com os testes de usuário com o protótipo final (avaliação/Artefato).

Tabela 8: Resultados da observação direta relativos ao exame de questões de projeto relacionadas à comunicabilidade da interface.

\begin{tabular}{|c|c|c|c|c|}
\hline \multirow{2}{*}{ Etapa } & \multicolumn{3}{|c|}{ Percentual de comunicação } & \multirow{2}{*}{ Média } \\
\cline { 2 - 4 } & Planejamento & Construção & Avaliação & \\
\hline $\begin{array}{c}\text { Prototipação da } \\
\text { forma }\end{array}$ & $50 \%$ & $15 \%$ & $37 \%$ & $34 \%$ \\
\hline $\begin{array}{c}\text { Prototipação do } \\
\text { Comportamento }\end{array}$ & -- & -- & $3 \%$ & $1 \%$ \\
\hline $\begin{array}{c}\text { Prototipação do } \\
\text { Artefato }\end{array}$ & $21 \%$ & $11 \%$ & $\begin{array}{c}64 \% \\
\text { (média) }\end{array}$ & $39 \%$ \\
\hline Média & $24 \%$ & $9 \%$ & $34 \%$ & $25 \%$ \\
\hline
\end{tabular}

No planejamento da etapa de Prototipação da Forma, boa parte do trabalho do grupo foi dedicado ao exame de questões relacionadas à comunicabilidade da interface $(50 \%)$. Nesta fase foram também discutidos os aspectos físicos relativos à interação usuário-tangível (abrir cartão, deslizar tira de papel, encher balão,...) e os aspectos tecnológicos envolvidos na implementação do protótipo Hi-fi. No planejamento durante a Prototipação do Artefato, a discussão foi mais voltada 
para questões envolvendo a construção do tangível (seleção de materiais, divisão do trabalho, imagens a serem utilizadas,...), uma vez que as questões relativas à interação usuário-tangível haviam sido discutidas previamente na etapa de planejamento da Prototipação da Forma. Mesmo assim, parte do planejamento (21\%) foi dedicada a questões envolvendo comunicabilidade também nesta etapa.

A maior parcela de comunicação do grupo dedicada à comunicabilidade ocorre durante a etapa de avaliação do protótipo Hi-fi (64\%), quando os designers discutem sobre as questões observadas no teste com o usuário utilizando como base a metamensagem elaborada.

O resultado da fase de avaliação desta etapa é a média dos resultados obtidos nas quatro avaliações, cada uma delas envolvendo um teste com usuário. No caso dos usuários sem conhecimento prévio sobre o uso de QR Codes (U2 e U3), parte da discussão do grupo foi dedicada às dificuldades observadas no uso da tecnologia, especificamente sobre a operação do dispositivo móvel e dos aplicativos. O teste da usuária U2, que dentre os usuários apresentou maior dificuldade no uso desta tecnologia, obteve o menor percentual de exames de questões relacionadas à comunicabilidade da interface (31\%), significativamente menor que as demais avaliações, refletindo a predominância das dificuldades observadas no QR Codes durante o teste. Os testes com os usuários U3 e U4 apresentaram os resultados mais altos, respectivamente $86 \%$ e $95 \%$. É importante destacar que nestes casos o grupo adotou (por iniciativa própria) uma dinâmica na condução da discussão sobre o teste diferente das duas primeiras avaliações, mais focada na metamensagem elaborada. Esta dinâmica envolveu a leitura de um trecho da metamensagem por um dos participantes e sua discussão pelo grupo logo em seguida, desta forma garantindo que todos os pontos da metamensagem fossem abordados. Com esta forma de condução, o foco nas questões de comunicabilidade foi predominante, mesmo no caso de usuário com dificuldade no uso da tecnologia (U3). Pode-se observar o efeito desta mudança ao se comparar os resultados dos usuários U1 (42\%) e U4 (95\%), ambos com domínio do uso da tecnologia, mas com avaliações conduzidas de forma diferente.

No caso da documentação (Tabela 9), na etapa de Prototipação da Forma, o teste com o protótipo Low-fi é simulado, com foco maior nos aspectos de projeto relacionados à forma, não havendo o uso 'real' da tecnologia. Os registros efetuados pelo grupo neste caso deram ênfase à interação do usuário com o 
tangível, que, em parte, envolveram questões relativas à comunicabilidade da interface.

Os resultados referentes à Prototipação do Artefato variaram entre $12 \%$ e $47 \%$. Esta variação se deveu em parte ao uso da tecnologia pelo usuário nos testes com o protótipo Hi-fi. Assim como no caso da observação direta, os usuários U2 e U3 apresentaram os resultados mais baixos, devido a dificuldades no uso da tecnologia. Outro fator que impactou na variação destes resultados foi a falta de uniformidade no preenchimento dos formulários devido à variedade de relatores. Três dos quatro designers se revezaram no papel de observador e, consequentemente, no preenchimento dos formulários, o que resultou em diferentes enfoques de registro e estilos de redação (resumido vs detalhado, descritivo vs reflexivo, ...). O formulário preenchido na Avaliação 3 pela designer D1, por exemplo, enfatizou a descrição das ações do usuário durante o teste em frases curtas (tópicos), enquanto na Avaliação 1 desta mesma fase, o designer D2 registra não só ações do usuário, mas impressões como “... percebeu que o convite é referente a uma festa", empregando frases mais longas e fornecendo mais informações sobre o item registrado. Esta diferença de estilo se reflete nos resultados deste estudo, o que pode ser verificado comparando-se os valores destes exemplos, apresentados na Tabela 9.

Tabela 9: Resultados da análise de documentos relativos ao exame de questões de projeto relacionadas à comunicabilidade da interface.

\begin{tabular}{|c|c|c|c|c|c|c|}
\hline \multirow{3}{*}{$\begin{array}{l}\text { Percentual de } \\
\text { comunicação }\end{array}$} & \multicolumn{5}{|c|}{ Etapa } & \multirow{3}{*}{ Média } \\
\hline & \multirow{2}{*}{\begin{tabular}{|c}
$\begin{array}{c}\text { Prototipação } \\
\text { da forma }\end{array}$ \\
$\begin{array}{c}\text { Avaliação } \\
1\end{array}$ \\
\end{tabular}} & \multicolumn{4}{|c|}{ Prototipação do Artefato } & \\
\hline & & $\begin{array}{c}\text { Avaliação } \\
1\end{array}$ & $\begin{array}{c}\text { Avaliação } \\
2\end{array}$ & $\begin{array}{l}\text { Avaliação } \\
3\end{array}$ & $\begin{array}{c}\text { Avaliação } \\
4\end{array}$ & \\
\hline $\begin{array}{l}\text { Percentual por } \\
\text { avaliação }\end{array}$ & $42 \%$ & $41 \%$ & $31 \%$ & $12 \%$ & $47 \%$ & $35 \%$ \\
\hline $\begin{array}{c}\text { Média por } \\
\text { etapa }\end{array}$ & $42 \%$ & \multicolumn{4}{|c|}{$33 \%$} & $37 \%$ \\
\hline
\end{tabular}

Outro ponto a ser destacado nesta análise refere-se à estrutura dos formulários. A parte inicial do formulário - campos "Observação" e "Comentários do usuário"-, tem por objetivo o registro dos pontos observados durante o teste e foram preenchidos predominantemente com relatos dos acontecimentos ocorridos considerados relevantes para futura discussão. As questões envolvendo a comunicabilidade da interface foram registradas em sua maioria no campo 
"Modificações indicadas" e "Recomendações...", preenchidos após a discussão em grupo.

No caso das entrevistas (Tabela 10), os resultados são individuais e referentes à comunicação entre o participante entrevistado e o entrevistador. No caso deste foco de análise, utilizou-se somente a Parte 1 da entrevista para a seleção de dados, cujo tópico foi o projeto de interface desenvolvido pelo grupo. Como os itens de roteiro relacionados a esta parte da entrevista não envolvem Engenharia Semiótica, quaisquer exames de questões de projeto relacionadas à comunicabilidade da interface por parte do entrevistado foram espontâneos.

Tabela 10: Resultados da entrevista relativos ao exame de questões de projeto relacionadas à comunicabilidade da interface.

\begin{tabular}{|c|c|c|c|c||c|}
\hline & \multicolumn{4}{|c|}{ Participantes } & \multirow{2}{*}{ Média } \\
\cline { 2 - 5 } & D1 & D2 & D3 & D4 & \\
\cline { 2 - 5 } $\begin{array}{c}\text { Percentual de } \\
\text { comunicação }\end{array}$ & $19 \%$ & $57 \%$ & $36 \%$ & $20 \%$ & $33 \%$ \\
\hline
\end{tabular}

Nas análises que consideraram todo o grupo (observação direta e documentação), todos os participantes estiveram simultaneamente envolvidos no exame de questões de projeto relacionadas à comunicabilidade da interface. Nestes casos, não é possível precisar as parcelas individuais de participação nas discussões e no preenchimento de documentação. Por este motivo, o mesmo valor é utilizado para todos os participantes no cálculo dos resultados finais individuais, apresentados na Tabela 11. Observa-se que o designer D2 apresentou o maior resultado, seguido de D3.

Tabela 11: Resultados individuais relativos ao exame de questões de projeto relacionadas à comunicabilidade da interface.

\begin{tabular}{|c|c|c|c|c|}
\hline \multirow{2}{*}{ Fonte } & \multicolumn{4}{|c|}{ Participantes } \\
\cline { 2 - 5 } Observação direta & D1 & D2 & D3 & D4 \\
\hline Documentação & \multicolumn{5}{|c|}{$25 \%$} \\
\hline $\begin{array}{c}\text { Entrevista } \\
\text { Individual }\end{array}$ & $19 \%$ & $57 \%$ & $36 \%$ & $20 \%$ \\
\hline Média & $28 \%$ & $40 \%$ & $33 \%$ & $28 \%$ \\
\hline
\end{tabular}




\subsubsection{Emprego correto de conceitos de Engenharia Semiótica}

A linguagem expressa o pensamento do indivíduo, suas opiniões e seus desejos. O conteúdo da linguagem é o resultado do conhecimento que os indivíduos desenvolvem em relação a pessoas, objetos, eventos e as relações entre eles (Bloom, 1978), e é expresso mediante a seleção de palavras. Tendo em vista a relação entre pensamento e palavra, os parâmetros definidos neste foco de análise têm por finalidade fornecer indícios relativos à aquisição e aplicação de conceitos por meio de referência direta ou indireta aos conceitos de Engenharia Semiótica enfocados no escopo desse estudo: (a) o foco na comunicação designers-usuários mediada pelo sistema, (b) a interface comunica uma mensagem do designer para os usuários e (c) a interface comunica ao usuário a metamensagem do designer.

Os parâmetros para análise no caso deste foco estão relacionados à ocorrência de referência (direta ou indireta) a estes conceitos com emprego correto. $^{28}$ As referências diretas correspondem ao uso de termos específicos (palavras, vocábulos), enquanto a referência indireta corresponde à menção do conceito sem o uso de um termo específico. Em função dos conceitos de Engenharia Semiótica considerados nesse estudo, os termos selecionados ${ }^{29}$ para a análise foram "mensagem" e "metamensagem", como nos exemplos:

- Referência direta à mensagem - "a gente conseguiu passar a mensagem de que era uma festa à fantasia" (D3), "estaria implícito na mensagem do cartão" (D2), "eu tenho minhas dúvidas se ele entendeu a mensagem" (D2);

- Referência indireta à mensagem - "como a gente indica que é uma festa?" (D3), "o que a gente não conseguiu passar pro usuário" (D3), "ela entendeu que era uma festa à fantasia" (D2), "ele percebeu que o convite é referente à Denise" (ficha de avaliação);

- Referência direta à metamensagem - "é o que está na metamensagem" (D4), "mas a gente pode mudar a metamensagem" (D1) e "vamos ver o que está na metamensagem" (D3).

- Referência indireta à metamensagem - "como eu escrevi a mensagem

\footnotetext{
${ }^{28}$ No escopo deste estudo, o emprego correto dos termos se refere exclusivamente à semântica, não considerando a construção gramatical da frase.

${ }^{29}$ Os termos "comunicabilidade" e "comunicação" não serão utilizados nesta análise. O primeiro por não ter sido abordado na aplicação do método e o segundo por não se tratar de um termo específico da Engenharia Semiótica.
} 
(se referindo a metamensagem elaborada pelo grupo), eu quero ver se a pessoa entendeu..." (D1).

O sistema de contagem de ocorrência de referência adotou um mecanismo de cálculo que envolve a anulação de um item correto para cada item incorreto, a fim de também contabilizar o emprego incorreto dos conceitos, que sinaliza ausência de compreensão. Entretanto, é importante destacar que a adoção deste sistema não teve nenhum impacto nos resultados, uma vez que não foi identificada nenhuma ocorrência de emprego incorreto dos conceitos, apenas problemas de construções de frase. Os resultados apresentados a seguir são, portanto, referentes ao emprego correto dos conceitos.

No caso da observação direta e das entrevistas, os resultados são individuais e referentes à comunicação entre os participantes ou entre entrevistado e entrevistador. $\mathrm{Na}$ análise da documentação, os resultados apresentados são relativos ao grupo.

Os resultados da observação direta nas etapas de prototipação são apresentados nas tabelas a seguir (Tabela 12 e Tabela 13). Os resultados relativos à observação direta na etapa de Prototipação do Comportamento foram omitidos por serem nulos, ou seja, não foi identificada nenhuma referência aos termos selecionados. Isto se deu devido ao enfoque dado à etapa na solução tecnológica (programação e circuito).

Tabela 12: Resultados da observação direta relativos ao emprego correto de conceitos de Engenharia Semiótica na etapa de Prototipação da Forma.

\begin{tabular}{|c|c|c|c|c|c|c|c|c|c|c|c|c|c|c|c|c|}
\hline \multirow{3}{*}{ Referência } & \multicolumn{16}{|c|}{ Número de ocorrências na etapa de Prototipação da Forma } \\
\hline & \multicolumn{5}{|c|}{ Planejamento } & \multicolumn{5}{|c|}{ Construção } & \multicolumn{5}{|c|}{ Avaliação } & \multirow[b]{2}{*}{ Total } \\
\hline & D1 & D2 & D3 & D4 & $\begin{array}{l}\text { Sub } \\
\text { total }\end{array}$ & D1 & D2 & D3 & D4 & $\begin{array}{c}\text { Sub } \\
\text { total }\end{array}$ & D1 & D2 & D3 & D4 & $\begin{array}{c}\text { Sub } \\
\text { total }\end{array}$ & \\
\hline $\begin{array}{l}\text { Referência diretaà } \\
\text { mensagem }\end{array}$ & -- & -- & -- & -- & -- & -- & 1 & -- & 1 & 2 & 0 & 2 & 0 & 1 & 3 & 5 \\
\hline $\begin{array}{l}\text { Referência diretaà } \\
\text { metamensagem }\end{array}$ & -- & -- & -- & -- & -- & -- & -- & -- & -- & -- & -- & -- & -- & -- & -- & -- \\
\hline $\begin{array}{l}\text { Referência indireta } \\
\text { à mensagem }\end{array}$ & 3 & 4 & 2 & 2 & 11 & 2 & -- & 2 & 1 & 5 & 2 & 5 & 3 & 2 & 12 & 28 \\
\hline $\begin{array}{l}\text { Referência indireta } \\
\text { à metamensagem }\end{array}$ & -- & -- & -- & -- & -- & -- & -- & -- & -- & -- & -- & -- & -- & -- & -- & -- \\
\hline Total & 3 & 4 & 2 & 2 & 11 & 2 & 1 & 2 & 2 & 7 & 2 & 7 & 3 & 3 & 15 & 33 \\
\hline
\end{tabular}


Tabela 13: Resultados da observação direta relativos ao emprego correto de conceitos de Engenharia Semiótica na etapa de Prototipação do Artefato.

\begin{tabular}{|c|c|c|c|c|c|c|c|c|c|c|c|c|c|c|c|c|}
\hline \multirow{3}{*}{ Referência } & \multicolumn{16}{|c|}{ Número de ocorrências na etapa de Prototipação do Artefato } \\
\hline & \multicolumn{5}{|c|}{ Planejamento } & \multicolumn{5}{|c|}{ Construção } & \multicolumn{5}{|c|}{ Avaliação } & \multirow[b]{2}{*}{ Total } \\
\hline & D1 & D2 & D3 & D4 & \begin{tabular}{|c|} 
Sub \\
total
\end{tabular} & D1 & D2 & D3 & D4 & $\begin{array}{l}\text { Sub } \\
\text { total }\end{array}$ & D1 & D2 & D3 & D4 & \begin{tabular}{|l|} 
Sub \\
total
\end{tabular} & \\
\hline $\begin{array}{l}\text { Referência direta } \\
\text { à mensagem }\end{array}$ & 2 & 3 & 2 & 2 & 9 & 3 & 2 & 1 & 2 & 8 & 10 & 19 & 12 & 13 & 54 & 71 \\
\hline $\begin{array}{l}\text { Referência diretaà } \\
\text { metamensagem }\end{array}$ & -- & -- & 1 & -- & 1 & -- & -- & -- & -- & 0 & 1 & 3 & 7 & 4 & 15 & 16 \\
\hline $\begin{array}{l}\text { Referência indireta } \\
\text { à metamensagem }\end{array}$ & -- & -- & -- & -- & -- & -- & -- & -- & -- & -- & -- & -- & -- & -- & -- & -- \\
\hline $\begin{array}{l}\text { Referência indireta } \\
\text { à metamensagem }\end{array}$ & -- & -- & -- & -- & -- & -- & -- & -- & -- & -- & -- & -- & -- & -- & -- & -- \\
\hline Total & 2 & 4 & 3 & 2 & 11 & 3 & 3 & 1 & 2 & 9 & 11 & 38 & 28 & 19 & 96 & 116 \\
\hline
\end{tabular}

Com relação ao número de ocorrências, é importante ressaltar que o número de horas de observação no caso das etapas de prototipação é o mesmo para todos os participantes, uma vez que as atividades foram realizadas em grupo. Os números de ocorrências são, portanto, relativos ao mesmo período de tempo. No entanto, vale também ressaltar que caraterísticas pessoais relacionadas à personalidade e estilo de comunicação pessoal no contexto de trabalho em grupo provavelmente influenciaram estes resultados. Uma pessoa mais comunicativa, por exemplo, tem maior probabilidade de uso de um termo específico.

$\mathrm{Na}$ análise de documentos (Tabela 14), novamente deve-se salientar a falta de uniformidade no preenchimento dos formulários devido à variedade de relatores como um fator que pode ter influenciado nos resultados obtidos. Independentemente deste fator, observa-se uma concentração maior de menções indiretas à metamensagem, indicando uma maior atenção à questão emissão (“deixar claro", "reforçar a frase”) e percepção (“ele entendeu”, "não está claro") da mensagem. 
Tabela 14: Resultados da análise de documentos relativos ao emprego correto de conceitos de Engenharia Semiótica.

\begin{tabular}{|c|c|c|c|c|c|c|}
\hline \multirow{3}{*}{ Referência } & \multicolumn{6}{|c|}{ Número de ocorrências } \\
\hline & \multirow{2}{*}{$\begin{array}{c}\text { Prototipação } \\
\text { da forma } \\
\begin{array}{c}\text { Avaliação } \\
1\end{array} \\
\end{array}$} & \multicolumn{4}{|c|}{ Prototipação do Artefato } & \multirow[b]{2}{*}{ Total } \\
\hline & & $\begin{array}{c}\text { Avaliação } \\
1\end{array}$ & \begin{tabular}{|c|} 
Avaliação \\
2
\end{tabular} & \begin{tabular}{|c|} 
Avaliação \\
3
\end{tabular} & $\underset{4}{\text { Avaliação }}$ & \\
\hline $\begin{array}{l}\text { Referência diretaà } \\
\text { mensagem }\end{array}$ & 1 & -- & -- & -- & -- & 1 \\
\hline $\begin{array}{l}\text { Referência direta à } \\
\text { metamensagem }\end{array}$ & -- & -- & -- & -- & -- & -- \\
\hline $\begin{array}{l}\text { Referência indireta } \\
\text { à mensagem }\end{array}$ & 4 & 6 & 5 & 1 & 4 & 20 \\
\hline $\begin{array}{l}\text { Referência indireta à } \\
\text { metamensagem }\end{array}$ & -- & -- & -- & -- & -- & -- \\
\hline Total & 5 & & 1 & & & 21 \\
\hline
\end{tabular}

No caso da entrevista, foi necessário criar um mecanismo para diminuir o impacto da variação de sua duração no número de ocorrências. Diferentemente da observação direta e dos formulários, o tempo de comunicação entre entrevistado e entrevistador teve durações variáveis, entre 18 e 31 minutos. Esta variação certamente influenciou os resultados inicialmente obtidos, uma vez que o participante com mais tempo de entrevista, tem maior chance de mencionar algum dos termos selecionados. O designer D2, por exemplo, teve o maior número de ocorrências (49) e o maior tempo de entrevista (31 minutos). No entanto, não é possível comparar este resultado com, por exemplo, o de D1 (7 ocorrências/18 minutos) por causa da diferença de duração das entrevistas. Para viabilizar a comparação destes valores, considerou-se como tempo-padrão o tempo mínimo (18 minutos) e os valores absolutos foram recalculados proporcionalmente, por meio da aplicação de regra de três simples. Os resultados obtidos com este ajuste são apresentados na Tabela 15.

Tabela 15: Resultados da entrevista relativos ao emprego correto de conceitos de Engenharia Semiótica.

\begin{tabular}{|c|c|c|c|c|c|}
\hline \multirow{2}{*}{ Referência } & \multicolumn{5}{|c|}{ Número de ocorrências por participante } \\
\cline { 2 - 6 } & D1 & D2 & D3 & D4 & Total \\
\hline $\begin{array}{c}\text { Referência direta à } \\
\text { mensagem }\end{array}$ & -- & 18 & 5 & -- & 23 \\
\hline $\begin{array}{c}\text { Referência direta à } \\
\text { metamensagem }\end{array}$ & 3 & 2 & 2 & 2 & 9 \\
\hline
\end{tabular}




\begin{tabular}{|c|c|c|c|c|c|}
\hline \multirow{2}{*}{ Referência } & \multicolumn{5}{|c|}{ Número de ocorrências por participante } \\
\cline { 2 - 6 } & D1 & D2 & D3 & D4 & Total \\
\hline $\begin{array}{c}\text { Referência indireta } \\
\text { àmensagem }\end{array}$ & 4 & 8 & 8 & 7 & 27 \\
\hline $\begin{array}{c}\text { Referência indiretaà } \\
\text { metamensagem }\end{array}$ & 1 & -- & -- & -- & 1 \\
\hline Total & 8 & 28 & 15 & 9 & 60 \\
\hline
\end{tabular}

Tanto a observação direta como as entrevistas fornecem dados individuais, mas no caso da documentação, as ocorrências de referência individual não podem ser identificadas. Por este motivo, o resultado na análise dos formulários é dividido pelo grupo ( 21 ocorrências / 4 participantes $\cong 5$ ocorrências / participante), admitindo igualdade no nível de contribuição dos participantes como mostra a Tabela 16. Nota-se nesta tabela que D2 apresentou o maior resultado e D1 o menor.

Tabela 16: Resultados individuais relativos ao emprego correto de conceitos de Engenharia Semiótica.

\begin{tabular}{|c|c|c|c|c|}
\hline \multirow{2}{*}{ Fonte } & \multicolumn{5}{|c|}{ Número de ocorrências por participantes } \\
\cline { 2 - 5 } & D1 & D2 & D3 & D4 \\
\hline Observação direta & 30 & 57 & 40 & 39 \\
\hline Documentação & \multicolumn{5}{|c|}{5} & 9 \\
\hline $\begin{array}{c}\text { Entrevista } \\
\text { Individual }\end{array}$ & 8 & 28 & 15 & 53 \\
\hline Total & 43 & 90 & 60 & \multirow{2}{*}{} \\
\hline
\end{tabular}

\subsection{Conclusão do capítulo}

As seções anteriores deste capítulo apresentam o estudo de caso realizado, sua caracterização, desenvolvimento e os resultados obtidos para cada foco de análise. $\mathrm{Na}$ conclusão deste capítulo, os resultados obtidos para cada foco são analisados em conjunto, visando identificar evidências da aquisição e a aplicação de conceitos de Engenharia Semiótica no projeto de tangíveis com a aplicação do método proposto. Nesta análise, a aquisição dos conceitos e sua aplicação são consideradas separadamente, levando em consideração os resultados individuais para os parâmetros definidos, apresentados na Tabela 17. 
Tabela 17: Resultados individuais para cada parâmetro de análise.

\begin{tabular}{|c|c|c|c|c|}
\hline \multirow{2}{*}{ Parâmetro } & \multicolumn{3}{|c|}{ Participante } \\
\cline { 2 - 5 } & D1 & D2 & D3 & D4 \\
\hline $\begin{array}{c}\text { Percentual de comunicação relativa } \\
\text { ao exame de questões de projeto } \\
\text { relacionadas à comunicabilidade }\end{array}$ & $28 \%$ & $40 \%$ & $33 \%$ & $28 \%$ \\
\hline $\begin{array}{c}\text { Número total de ocorrências de } \\
\text { referências a conceitos de Engenharia } \\
\text { Semiótica }\end{array}$ & 43 & 90 & 60 & 53 \\
\hline
\end{tabular}

Nota-se que há significativa diferença entre os resultados individuais. O designer D2, por exemplo, fez mais do que o dobro de referências aos conceitos e se dedicou três vezes mais ao exame de questões de projeto relacionadas à comunicabilidade do que o designer D1. Esta diferença não está relacionada à aquisição ou aplicação do conceito, mas à sua apropriação, isto é: ao ato de tornar próprio algo (um processo, conceito, ponto de vista,...) de outrem (Wertsch, 1998 apud Haugerud, 2011). O nível de apropriação de um conceito está ligado a motivações, intenções, crenças, atitudes e valores pessoais que fogem ao mérito da aplicação do método proposto. Por este motivo, a questão da apropriação dos conceitos não foi considerada no escopo deste trabalho.

Dois dos designers (D1 e D3) possuíam algum conhecimento inicial sobre Engenharia Semiótica. Como o nível de compreensão e retenção dos conceitos abordados neste estudo não foram testados inicialmente, não é possível determinar se houve ou não contribuição desta experiência de projeto de interface para a aquisição dos conceitos por estes designers. No caso dos demais participantes (D2 e D4), que não possuíam conhecimento inicial sobre Engenharia Semiótica, observa-se que os designers demonstraram a capacidade de empregar os conceitos de forma correta, fazendo referência ao conceito direta ou indiretamente e estabelecendo relações válidas entre estes conceitos e o projeto do tangível. Tomando a capacidade demonstrada como evidência, pode-se afirmar que, no caso dos designers que não possuíam conhecimento inicial, o método contribui para a aquisição de conceitos de Engenharia Semiótica no projeto de interfaces tangíveis.

Com relação à aplicação individual dos conceitos, independente do nível de apropriação, todos os participantes dedicaram uma parcela significativa de tempo da comunicação entre o grupo e com o entrevistador no exame de questões de projeto relacionadas à comunicabilidade (menor valor $=28 \%$ ). 
Um quarto do tempo de trabalho no desenvolvimento do tangível foi empregado no exame de questões relacionadas à comunicabilidade da interface (Tabela 8), sendo que a maior parte deste exame se concentra no início, durante o processo de ideação do tangível e nos testes de usuário com o protótipo final. Nota-se pelos resultados da observação direta que as atividades propostas pelo método que envolvem especificamente a aplicação de conceitos de Engenharia Semiótica (introdução de conceitos, preenchimento do Formulário de Metamensagem, elaboração da metamensagem, avaliações com base no Formulário de Metamensagem e na Metamensagem) refletiram nos valores referentes à parcela de tempo dedicada às questões de comunicabilidade nas ocasiões correspondentes do processo de prototipação, indicando a eficácia destas atividades na promoção da aplicação dos conceitos e, consequentemente, do método proposto.

Considerando que a eficácia do método proposto na promoção da aplicação dos conceitos e que os participantes dedicaram uma parcela significativa de tempo no exame de questões de projeto relacionadas à comunicabilidade $(25 \%)$, concluise que o método proposto contribui para a aplicação de conceitos no projeto de interface tangíveis.

Com a realização deste estudo de caso foi possível alcançar o objetivo principal propostos nesta pesquisa, que é investigar se o método proposto contribui para a incorporação da perspectiva da Engenharia Semiótica ao projeto de interfaces tangíveis. No capítulo a seguir, são tecidas algumas considerações acerca do método e das conclusões apresentadas neste capítulo, e são apresentadas algumas sugestões para trabalhos futuros. 


\section{Considerações finais}

Neste trabalho foram abordadas algumas questões relativas ao projeto de interfaces tangíveis, uma delas é a questão que motivou este estudo: como apoiar os designers no projeto de interfaces tangíveis adotando a abordagem centrada na comunicação proposta pela Engenharia Semiótica? Considerando esta questão, a principal contribuição deste trabalho é oferecer aos designers um método fundamentado na Engenharia Semiótica que apoie o projeto de interfaces tangíveis, sem que os designers necessitem ter conhecimento prévio de conceitos de Engenharia Semiótica. O método, denominado Prototipação Colaborativa de Tangíveis Baseada na Engenharia Semiótica, composto por três etapas Prototipação da Forma, Prototipação do Comportamento e Prototipação do Artefato -, combina as abordagens de prototipação e da Engenharia Semiótica no projeto de interfaces tangíveis.

Este método visa incorporar à abordagem de prototipação a perspectiva centrada na comunicação designer-usuário mediada pela interface no projeto do tangível. Tendo este objetivo em vista, o método foi estruturado de modo a contribuir para a aquisição e aplicação de conceitos de Engenharia Semiótica no projeto da interface ao longo do processo de prototipação. O estudo de caso conduzido comprovou a contribuição do método para a aquisição e aplicação destes conceitos no projeto de interface tangível (Seção 5.4).

Um ponto a ser comentado sobre este resultado é a possibilidade de sua generalização com base no estudo de caso, especialmente no caso de Estudo de Caso Único. César (2005) afirma que "pensa-se num caso geralmente como um único membro de uma dada população e, como tal, fracamente representando a população; assim, o estudo deste caso forneceria fraca base para generalização". Nesse sentido os Estudos de Casos Múltiplos e/ou as replicações de um Estudo de Caso com outras amostras podem indicar o grau de generalização de proposições. A replicação deste caso com outras amostras (participantes) seria também um 
recurso para se minimizar a influência do perfil dos participantes nos resultados, lembrando que o número reduzido de amostras em cada caso é característico das pesquisas qualitativas, como ressalta Leitão (2009):

"O fato de os métodos qualitativos trabalharem com foco restrito e amostra de tamanho reduzido é outra preocupação presente no contexto de IHC. É importante perceber, no entanto, que as pesquisas qualitativas têm foco restrito e amostra reduzida não por limitações de concepção ou execução, mas em função de sua ênfase na análise microscópica e em profundidade da questão de estudo.”

Uma diferente abordagem com relação aos resultados obtidos neste estudo é originada do conceito de Linguagem de Design ${ }^{30}$ (Gibbons et al., 2004):

"Linguagem de Design é um conjunto de abstrações (conceitos) usadas para dar estrutura, propriedades e textura a problemas de design. [...] Linguagens de Design oferecem aos designers uma ferramenta para discutir com maior precisão sobre as decisões de design. [...] O que torna uma linguagem de design distinta da linguagem natural é a sua semântica exclusiva, não compartilhada pela população geral de usuários da linguagem”.

No Design, "as palavras que usamos codificam conceitos especiais ou profissionais que nos auxiliam a explorar um espaço de problema e identificar, refinar e planejar uma solução" (Goodwin, 1994). Segundo Gibbons et al. (2004), os termos de uma linguagem de design denotam objetos, atores, ações, conceitos, tipos de relação, qualidades e propriedades; e seu uso mais comum é na solução conjunta de problemas pelos membros da equipe de design.

A comunicação entre a equipe de designers na construção do projeto foi baseada no uso de uma linguagem compartilhada, com a aplicação de termos de Engenharia Semiótica no projeto de tangíveis, o que configura o uso de uma linguagem de design na qual os termos primitivos são centrados em uma teoria. Gibbons et al. (2004) destaca que, além de melhorar a comunicação entre os designers, o uso de uma linguagem de design possibilita maior orientação da teoria no projeto, o que corrobora os resultados desta pesquisa.

Dentre os benefícios do método relacionados na Seção 4.5, destacam-se a possibilidade de experimentação com diferentes ideias relacionadas ao projeto do tangível (prototipação) e o enfoque na comunicabilidade da interface e a metamensagem resultante (Engenharia Semiótica), que o torna mais adequado à

${ }^{30}$ A noção de linguagem de design aqui adotada difere do termo utilizado por Rheinfrank e Evenson (1996), que dá ênfase na comunicação de designers com usuários. A ênfase aqui é o uso de linguagem de design na comunicação entre os próprios designers. 
aplicação dos métodos de avaliação propostos pela Engenharia Semiótica - MIS e MAC. Alguns outros benefícios do método foram destacados pelos participantes (Apêndice D), dentre eles: o foco dado à comunicabilidade na avaliação do tangível com o uso da metamensagem e a metamensagem como uma forma de documentação do projeto.

Com relação ao método proposto neste trabalho, vislumbram-se algumas oportunidades de desenvolvimento de trabalhos futuros, dentre eles, a investigação de:

- A adaptação deste método para outros tipos de interface (dispositivos móveis, superfícies interativas, realidade aumentada,...);

- Sua utilização em conjunto com os métodos de avaliação MIS e MAC propostos pela Engenharia Semiótica;

- A aplicação deste método em contexto educacional, como parte do método de ensino; e

- A avaliação do valor agregado ao processo de design de interface ou ao produto gerado (protótipo da interface) com a incorporação da aplicação de conceitos da Engenharia Semiótica no processo de prototipação, como proposto pelo método.

Um aspecto importante a ser avaliado futuramente acerca da aplicação do método é o valor agregado ao processo ou produto gerado (protótipo) com a aquisição e aplicação de conceitos da Engenharia Semiótica no projeto de interfaces tangíveis como proposto pelo método.

Os designers "desejam que os usuários de seus artefatos compreendam e vivenciem os benefícios de seu design" (de Souza et al., 2010) e, certamente, se favorecem de métodos que os apoiem no projeto de interfaces. No entanto, o estudo de interfaces tangíveis ainda é uma área pouco explorada em IHC, deixando muitas lacunas a serem preenchidas no tocante a teorias e métodos para o projeto destas interfaces. O trabalho aqui apresentado representa um importante passo inicial no estudo de projeto de interfaces tangíveis ao propor um método baseado na Engenharia Semiótica. 


\section{Referências Bibliográficas}

AGUIAR, Y.; LULA,B.; LIMA, C.; LIMA, G.; GOUVEIA, R. Uso de Protótipos no Processo de Concepção de Interfaces do Usuário. In: CONGRESSO DE PESQUISA E INOVAÇÃO DA REDE NORTE NORDESTE DE EDUCAÇÃO TECNOLÓGICA (CONNEPI'07), 2., 2007, João Pessoa, Brasil. Anais eletrônicos... Disponível em: <http://www.redenet.edu.br/publicacoes/ publicacoes.php?ligacao=2>. Acesso em: 04 mar. 2014.

ARNOWITZ, J.; ARENT, M.; BERGER, N. Effective Prototyping for Software Makers. São Francisco, EUA: Morgan-Kaufmann, 2007. 624 p.

BANGA, M.; TIMPKAA, T. Ubiquitous computing to support co-located clinical teams: Using the semiotics of physical objects in system design. International Journal of Medical Informatics, Amsterdã, v.76, n.1, 2007, p. S58-S64, Jun. 2007.

BARBOSA, S.D.J.; DA SILVA, B.S. Interação Humano-Computador. Rio de Janeiro: Elsevier, 2010. 384 p.

BEAUDOUIN-LAFON, M.; MACKAY, W.E. Prototyping tools and techniques. In: SEARS, A.; JACKO, A. (Eds.), Human-Computer Interaction Handbook: Fundamentals, Evolving Technologies, and Emerging Applications (2 ${ }^{\mathrm{a}}$ Ed.), Boca Raton: CRC Press, 2007, p.1017-1039.

BIM, S. Obstáculos ao ensino dos métodos de avaliação de Engenharia Semiótica. Rio de Janeiro, 2009. 181 p. Tese de doutorado - Departamento de Informática, Pontifícia Universidade Católica do Rio de Janeiro.

BLOOM, L.; LAHEY, M. Language development and language disorders, Nova Iorque: John Wiley \& Sons, 1978.

BONANNI, L.; ISHII, H. Stop-motion prototyping for tangible interfaces. In: INTERNATIONAL CONFERENCE ON TANGIBLE, EMBEDDED AND EMBODIED INTERACTION (TEI'09), 3., 2009, Cambridge, United Kingdom. Proceedings... Cambridge: IEEE, 2009, p.315-316.

BOWMAN, D. A.; KRUIJFF, E.; LA VIOLA JR, J. J.; POUPYREV, I. 3D User Interfaces: Theory and Practice. Boston: Addison-Wesley Professional, 2004, $512 p$.

BRADE, M.; KECK, M.; GRÜNDEL, T.; MÜLLER, M.; GROH, R. Natural Interface Exploration. In: INTERNATIONAL CONFERENCE ON TANGIBLE, EMBEDDED AND EMBODIED INTERACTION (TEI'13), 8., 2014, Monique, Alemanha. Proceedings... Nova Iorque: ACM, 2014, p.427-430.

BUXTON, B. Sketching User Experience: Getting the right Design and the Design Right. São Francisco: Morgan-Kaufmann, 2007. 448 p. 
CARDADOR, D.; UGULINO, W.; VEJA, K.; FILIPPO, D.; RAPOSO, A.; FUKS, H. Uma abordagem sistemática de prototipação colaborativa para a criação de tangíveis. In: SIMPÓSIO BRASILEIRO DE SISTEMAS COLABORATIVOS (SBSC'13), 5., 2013, Manaus, Brasil. Anais... Manaus: SBC, 2013, p.56-63.

CASTRO, A. A. Revisão sistemática e meta-análise. Disponível em: $<$ http://www.metodologia.org/meta1>. Acesso em: 25 fev. 2014.

CESAR, A.M.R.V.C. Método do estudo de caso (case studies) ou método do caso (reaching cases)? Uma análise dos dois métodos no ensino e pesquisa em administração. Revista Eletrônica Mackenzie de Casos (REMAC), São Paulo, v.1, n.1, jul./dez/ 2005. Disponível em: <http://www.mackenzie/fileadmin/ Graduacao/CCSA/remac/jul_dez_05/06.pdf>. Acesso em 03 dez. 2013.

CHANG, A.; GOULDSTONE, J; ZIGELBAUM, J.; ISHII, H. Simplicity in Interaction Design. In: INTERNATIONAL CONFERENCE ON TANGIBLE, EMBEDDED AND EMBODIED INTERACTION (TEI'07), 1., 2007, Baton Rouge, Louisiana. Proceedings... Nova Iorque: ACM, 2007, p.135-138.

CHRISTOU, G.; RITTER, F. E.; JACOB, R. J. K. Codein-A New Notation for GOMS to Handle Evaluations of Reality-Based Interaction Style Interfaces. International Journal of Human-Computer Interaction, v.28, n.3, 2012, p.189-201. Disponível em: <http://www.tandfonline.com/doi/full/10.1080/ 10447318. 2011.581893\#.UyCjdPldUrU>. Acesso em: 05 nov. 2013.

DANESI, M.; PERRON, P. Analysing Cultures: An Introduction and Handbook. Bloomington: Indiana University Press, 1999. 413p.

DE FRANÇA, R.S.; DO AMARAL, H.J.C. Prototipação rápida de aplicação interativa: uma experiência no domínio educacional. In: INTERNATIONAL CONFERENCE ON ENGINEERING AND COMPUTER EDUCATION, 8., 2013, Angola, Luanda. Proceedings... Disponível em: <http://www.copec.org.br/ icece2013/>. Acesso em: 15 jun. 2013.

DE PAULA, M.G. Projeto da interação humano-computador baseado em modelos fundamentados na engenharia semiótica: construção de um modelo de interação. Rio de Janeiro, 2003. 87 p. Dissertação de Mestrado - Departamento de Informática, Pontifícia Universidade Católica do Rio de Janeiro.

DE SOUZA; C.S. Semiotics. In: SOEGAARD, M.; DAM, R.F. (Eds.), The Encyclopedia of Human-Computer Interaction ( $2^{\mathrm{a}} \mathrm{Ed}$.). Aarhus, Denmark: The Interaction Design Foundation, 2013. Disponível em: <http://www.interactiondesign.org/encyclopedia/semiotics_and_human-computer_interaction.html>.

Acesso em: 10 mar 2013.

; LEITÃO, C.F.; PRATES, R.O.; BIM S.A.; DA SILVA, E.J., Can inspection methods generate valid new knowledge in HCI? The case of semiotic inspection. International Journal of Human-Computer Studies, v.68 n.1-2, p.22-40, January, 2010.

; LEITÃO, C.F.; PRATES, R.O.; SILVA, E. The Semiotic Inspection Method. In: SIMPÓSIO BRASILEIROS DE FATORES HUMANOS EM SISTEMAS COMPUTACIONAIS, 5., 2006, Natal, RN. Anais... Nova Iorque: ACM, 2006, p.148-157. 
.The semiotic engineering of human-computer interaction. Cambridge, MA: The MIT Press, 2005. 283 p.

; BARBOSA, S.D.J.; PRATES, R.O. A semiotic engineering approach to user interface design. Knowledge Based Systems, Amsterdã, v.14, n.8, p.461465, 2001.

DÖRING, T.; SYLVESTER, A.; SCHMIDT, A. Exploring material-centered design concepts for tangible interaction. In: ACM SIGCHI CONFERENCE ON HUMAN FACTORS IN COMPUTING SYSTEMS, 30., 2012, Austin, Texas. Extended Abstracts... Nova Iorque: ACM, 2012, 1523-1528 p.

; PFLEGING, B.; KRAY, C; SCHMIDT, A. Design by physical composition for complex tangible user interfaces. In: ACM SIGCHI CONFERENCE ON HUMAN FACTORS IN COMPUTING SYSTEMS, 2010, Atlanta, Georgia. Extended Abstracts... Nova Iorque: ACM, 2010, p.3541-3546.

ECO, U. A Theory of Semiotics. Bloomington: Indiana University Press, 1976.

EDGE, D.; BLACKWELL, A. Correlates of the Cognitive Dimensions for Tangible User Interface. Journal of Visual Languages \& Computing, Amsterdã, v.17, n.4, 2006, p.366-394, ago. 2006.

FALUDI，R. XBee Lilypad. 2008. Disponível em: <http://www.faludi.com/ 2008/06/15/xbee-lilypad>. Acesso em: 10 dez. 2012.

FELTHAM, F. G. Do the blocks rock: a tangible interface for play and exploration. In: CONFERENCE ON COMPUTER-HUMAN INTERACTION: DESIGNING FOR HABITUS AND HABITAT, 20., 2008, Cairns, Austrália. Proceedings... Nova Iorque: ACM, 2008, p.188-194.

FILIPPO, D. Suporte à Coordenação em Sistemas Colaborativos: uma pesquisaação com aprendizes e mediadores atuando em fóruns de discussão de um curso a distância. Rio de Janeiro, 2008. 281p. Tese de Doutorado - Departamento de Informática, Pontifícia Universidade Católica do Rio de Janeiro.

FJELD, M.; MORF, M.; KRUEGER, H. Activity theory and the practice of design: Evaluation of a collaborative tangible user interface. International Journal of Human Resources Development and Management, v.4, n.x, 2004, p.96-116. Disponível em: <http://www.inderscience.com/info/inarticle.php?artid $=4495>$. Acesso em: 10 nov. 2012 .

GIBBONS, A. S.; BOTTURI, L.; BOOT, E.; NELSON, J. Design languages. In: SPECTOR, J.M.; MERRILL, M. D.; ELEN, J., BISHOP, M .J. (Eds.), Handbook of Research for Educational Communications and Technology, $4^{\mathrm{a}}$ ed. Londres: Springer, 2008, p. 633-645.

GIBSON, J.J. The Theory of Affordances (1979). In: GIESEKING, J.J.; MANGOLD, W.; KATZ, C.; LOW, S.; SAEGERT S. (Eds.), The People, Place, and Space Reader. Oxon: Routledge, 2014, p.56-60.

GREENBERG, S.; CARPENDALE, S.; MARQUARDT, N.; BUXTON, B. Sketching User Experiences: The Workbook. Waltham: Morgan Kaufmann Publishers, 2011. 262 p.

GOODWIN, C. Professional vision. American Anthropologist, v.96, n.3, p. 606-633, set.1994. 
HAAK, M.; DE JONG, M.; SCHELLENS, P. J. Retrospective vs. concurrent think-aloud protocols: testing the usability of an online library catalogue. Behaviour \& Information Technology, Londres, v.22, n.5, p. 339-351, set-out. 2003.

HAUGERUD, T. Student Teachers Learning to Teach: The Mastery and Appropriation of Digital Technology. Nordic Journal of Digital Literacy, Oslo, v.6, n.4, p.226-238, nov. 2011.

HSIEH, C.; LIU, I.; YU, N.; CHIANG, Y.; WU, H.; CHEN, Y.; HUNG, Y. Yongzheng emperor's interactive tabletop: seamless multimedia system in a museum context. In: INTERNATIONAL CONFERENCE ON MULTIMEDIA (MM'10), 2010, Firenze, Itália. Proceedings... Nova Iorque: ACM, 2007, p.1453-1456.

ISHII, H. Tangible Bits: Beyond Pixels. In: INTERNATIONAL CONFERENCE ON TANGIBLE, EMBEDDED AND EMBODIED INTERACTION (TEI'08), 2 ., 2008, Bonn, Alemanha. Proceedings... Nova York: ACM, 2008, p.15-25.

; RATTI, C.; PIPER, B.; WANG, Y.; BIDERMAN, A.; BEN-JOSEPH, E. Bringing Clay and Sand into Digital Design - Continuous Tangible user Interfaces. BT Technology Journal, Londres, v.22, n.4, 2004, p.287-299, out. 2004.

; ULLMER, B. Tangible bits: towards seamless interfaces between people, bits and atoms. In: ACM CONFERENCE ON HUMAN FACTORS IN COMPUTING SYSTEMS (CHI'97), 1997, Atlanta, EUA. Proceedings... Nova York: ACM, 1997, p.234-241.

JACOB, R.J.K.; LEANNE, A.G.; HIRSHFIELD, L.M.; HORN M.S.; SHAER; O.; TREACY E.S.; ZIGELBAUM, J. Reality-Based Interaction: A Framework for Post-WIMP Interfaces. In: SIGCHI CONFERENCE ON HUMAN FACTORS IN COMPUTING SYSTEMS (CHI'08), 28., 2008, Florença, Itália. Proceedings... Nova York: ACM, 2008, p.201-210.

JINGYAN, Q.; YAN, G.; HUIWEN, J. TUI interactive product design. In: INTERNATIONAL CONFERENCE ON COMPUTER-AIDED INDUSTRIAL DESIGN \& CONCEPTUAL DESIGN, 10., 2009, Wenzhou, China. Proceedings... Piscataway: IEEE, 2009, p.1455-1458.

KARANA, E.; HEKKERT, P. User-Material-Product Interrelationships in Attributing Meanings. International Journal of Design, v.4, n.3, dez. 2010. Disponível em: <http://www.ijdesign.org>. Acesso em: 10 out. 2013.

KITCHENHAM, B.A.; CHARTERS, S. Guidelines for performing systematic literature reviews in software engineering - A Tertiary Study. Information and Software Technology, Amsterdã, v.52, n.8, p.792-805. Ago. 2010.

KORTUM, P. (Ed.). HIC Beyond the GUI: Design for Haptic, Speech, Olfactory, and Other Nontraditional Interfaces. Burlington: Morgan Kaufmann Publishers, 2008. 462 p.

KRIPPENDORFF, K.; BUTTER, R. Semantics: Meanings and Contexts od Artefacts. Filadélfia: Universidade da Pensilvânia, EUA, Escola para Comunicação Annenberg, 2007. 24p. Disponível em: <http://ijdesign.org/ojs/ index.php/IJDesign/article/view/635/312>. Acesso em: 03 nov. 2013. 
LEITÃO, C.F. Métodos Qualitativos de Pesquisa Científica. Computação Brasil: Interação Humano-Computador no Brasil, Porto Alegre, n.11, 2009, p.22-23, out. 2009.

LIN, J.; THOMSEN, M.; LANDAY, J. A. A Visual Language for Sketching Large and Complex Interactive Designs. In: SIGCHI CONFERENCE ON HUMAN FACTORS IN COMPUTING SYSTEMS (CHI'02), 20., 2002. Minneapolis, EUA. Proceedings... Nova York: ACM, 2002, p.307-314.

MAQUIL, V.; PSIK, T.; WAGNER, I. The ColorTable - A Design Story. In: TANGIBLE, EMBEDDED AND EMBODIED INTERACTION, 2., 2008, Bonn, Alemanha. Proceedings... Nova York: ACM, 2008, p.97-104.

MARCONI, M.A., LAKATOS, E.M. Fundamentos da Metodologia Científica. São Paulo: Atlas, 2003.

MATTOZZI, A. A model for the Semiotic Analysis of Objects. In: VIHMA, S. (Ed.), Design Semiotics in Use. Helsinki: Aalto University Press, 2010.

MENDES, G.A.V.; DE MIRANDA, L.C.; DE MIRANDA, E.E.C.; DA SILVA, L.F. Prototipação de interfaces tangíveis de produtos interativos: estado da arte e desafios da plataforma arduino. In: BRAZILIAN SYMPOSIUM ON HUMAN FACTORS IN COMPUTING SYSTEMS, 11., 1999, Porto Alegre. Proceedings... Nova Iorque: ACM, 2012, p.249-258.

MOURA, H.; CARDADOR, D.; VEGA, K.; UGULINO, W; BARBATO, M.; FUKS, H. Collaborative Museums: An Approach to Co-Design. In: ACM CONFERENCE ON COMPUTER SUPPORTED COOPERATIVE WORK, 2011 (CSCW'11), Hangzhou, China. Proceedings... Nova York: ACM, 2011, p.681684.

NASMAN, J.; CUTLER, B. Evaluation of user interaction with daylighting simulation in a tangible user interface. Automation in Construction, Amsterdã, 2013, v.36, dez. 2013.

NICOLACI-DA-COSTA, A. M.; LEITÃO, C. F.; ROMÃO-DIAS, D. Como conhecer usuários através do Método de Explicitação do Discurso Subjacente (MEDS). In: SIMPÓSIO SOBRE FATORES HUMANOS EM SISTEMAS COMPUTACIONAIS, 6. 2004, Curitiba, Proceedings... Porto Alegre: SBC, 2011, p.47-56.

NIELSEN, J. Usability Engineering. São Francisco: Morgan-Kaufman, 2006. $362 \mathrm{p}$.

PASCHOARELLI, L.C.; SILVA, D.C.; DA SILVA, J.C.P. Metodologia de Design de Instrumentos Manuais: Mock-Ups e Protótipos na Avaliação Ergonômica. In: MENEZES, M.S; PASCHOARELLI, L.C.; MOURA, M. (Orgs.), Metodologia em Design: Inter-relações, São Paulo: Estação das Letras e Cores, 2011. 344 p.

PIRHONEN, A.; MURPHY, E. Designing for the unexpected: the role of creative group work for emerging interaction design paradigms. Visual Communication, Nova Iorque, 2008, v.7, n.3, p.331-344, Ago. 2008.

PRATES, R.O.; BARBOSA, S.D.J. Introdução à Teoria e Prática da Interação Humano Computador fundamentada na Engenharia Semiótica. In: KOWALTOWSKI, T.; BREITMAN, K. (Orgs.). Atualizações em informática 
2007. XXVII Congresso da Sociedade Brasileira de Computação. Jornadas de Atualização em Informática (JAI), JAI/SBC 2007. Julho de 2007.

RATTI, C.; WANG, W.; ISHII, H.; PIPER, B.; FRENCHMAN, D. Tangible User Interfaces (TUIs): A Novel Paradigm for GIS. Transactions in GIS, Nova Jersey, v.8, n.4, p.407-421, out.2004.

RHEINFRANK, J.; EVENSON, S. Design languages. In: WINOGRAD T. (Ed.), Bringing Design To Software. Nova Iorque: ACM Press, 1996, p. 63-85.

RUDIO, F. V. Introdução ao Projeto de Pesquisa Científica. 24 ed. Petrópolis: Editora Vozes, 1999.144 p.

SCHMID, M.; RÜMELIN, S.; RICHTER, H. Empowering Materiality: Inspiring the Design of Tangible Interactions. In: INTERNATIONAL CONFERENCE ON TANGIBLE, EMBEDDED AND EMBODIED INTERACTION (TEI'13), 8., 2014, Monique, Alemanha. Proceedings... Nova Iorque: ACM, 2014, p.91-98.

SCHÖN, D. The Reflective Practitioner: How professionals think in action. Londres: Temple Smith, 1983. 384 p.

SCHRAGE, M. The culture(s) of prototyping. Design Management Journal, Boston, v.4, n.1, p.55-65, nov.1993.

SHAER, O.; JACOB, R. J. K. A specification paradigm for the design and implementation of tangible user interfaces. Transactions on Computer-Human Interaction, Nova Iorque, v.16, n.4, 2009, p.20:1-20:39, nov.2009.

SHARLIN, E.; WATSON, B.; KITAMURA, K.; KISHINO, F.; ITOH, Y. On tangible user interfaces, humans and spatiality. Personal and Ubiquitous Computing, Londres, v.8, n.5, p.338-346, set. 2004.

SILVA, B.S. MoLIC segunda edição: revisão de uma linguagem para modelagem da interação humano-computador. Rio de Janeiro, 2005. 175 p. Dissertação de Mestrado - Departamento de Informática, Pontifícia Universidade Católica do Rio de Janeiro.

SIEFKES, M. The semantics of artefacts: How we give meaning to the things we produce and use. Journal of Interdisciplinary Image Science (IMAGE), Helsinki, n.16, jul. 2012. p.61-91. Disponível em: <http://www.gib.unituebingen.de/image>. Acesso em: 10 dez. 2013.

SNYDER, C. Paper Prototyping: The Fast and Easy Way to Design and Refine User Interfaces. São Francisco: Morgan-Kaufmann, 2003. 408 p.

TEIXEIRA, J. M.; MATOS, L. M.; PERASSI, R. Analise semiótica da imagem de uma cadeira. Estudos Semióticos, São Paulo, v.7, n.2, p. 102-109, nov. 2010.

WEISER, M. The Computer for the 21 st Century. Scientific American, Nova Iorque, v.265, n.3, p.94-104, set. 1991.

WENSVEEN, S. A. G.; DJAJADININGRAT, J. P.; OVERBEEKE, C. J. Interaction frogger: a design framework to couple action and function through feedback and feedforward. In: DESIGNING INTERACTIVE SYSTEMS: PROCESSES, PRACTICES, METHODS, AND TECHNIQUES, 5., 2004, Cambridge, EUA. Proceedings... Nova Iorque: ACM, 2004, p.177-184.

WESTERLUND, B. Form is Function. In: CONFERENCE ON DESIGNING INTERACTIVE SYSTEMS: PROCESSES, PRACTICES, METHODS, AND 
TECHNIQUES, 4., 2002, Londres, Inglaterra. Proceedings... Nova Iorque: ACM, 2002, p.117-124.

WIETHOFF, A.; SCHNEIDER, H.; KÜFNER, J.; ROHS M.; BUTZ, A.; GREENBERG, S. Paperbox - A toolkit for exploring tangible interaction on interactive surfaces. Calgary: Universidade de Calgary, Departamento de Computação, 2013, 10p. Disponível em: <http://grouplab.cpsc.ucalgary.ca/ Publications>. Acesso em: 20 jan. 2013.

; SCHNEIDER, H.; ROHS, M.; BUTZ, A.; GREENBERG, S. Sketch-aTUI: low cost prototyping of tangible interactions using cardboard and conductive ink. In: INTERNATIONAL CONFERENCE ON TANGIBLE, EMBEDDED AND EMBODIED INTERACTION, 6., 2012, Kingston, Canadá. Proceedings... Nova York: ACM, 2012, p.309-312.

; BROLL, G. SoloFind: chains of interactions with a mobile retail experience system. In: ACM CONFERENCE ON HUMAN FACTORS IN COMPUTING SYSTEMS, 2011, Vancouver, Canadá. Extended Abstracts... Nova Iorque: ACM, 2011, p.1303-1308.

WITT, H.; NICOLAI, T.; KENN, H. Designing a wearable user interface for hands-free interaction in maintenance applications. In: INTERNATIONAL CONFERENCE ON PERVASIVE COMPUTING AND \COMMUNICATIONS WORKSHOP (PerCom 2006), 4., 2006, Pisa, Itália. Workshops... Los Alamitos, CA: IEEE, 2006, p.652-655.

YAO, L.; NIIYAMA, R.; OU, J.; FOLLMER, S.; SILVA, C.D.; ISHII, H. PneUI: pneumatically actuated soft composite materials for shape changing interfaces. In: ACM SYMPOSIUM ON USER INTERFACE SOFTWARE AND TECHNOLOGY (UIST'13), 26., 2013, St. Andrews, Escócia. Proceedings... Nova Iorque: ACM, 2013, p.13-22.

; DASGUPTA, S.; CHENG, N.; SPINGARN-KOFF, J.; RUDAKEVYCH, O.; ISHII, H. Rope Revolution: tangible and gestural rope interface for collaborative play. In: INTERNATIONAL CONFERENCE ON ADVANCES IN COMPUTER ENTERTAINMENT TECHNOLOGY, 8. 2011, Lisboa, Portugal. Proceedings... Nova Iorque: ACM, 2011, p.11:1-11:8.

YIN, R. Case Study Research: Design and Methods, $2^{\mathrm{a}}$ ed. Thousand Oaks: SAGE Publications, 1994. 192 p.

YOUNG, E.; GREENLEE, R. Participatory Video Prototyping. In: Posters and Short Talks of the 1992 SIGCHI Conference on Human Factors in Computing Systems (CHI). 1992, Monterey, EUA. Proceedings... Nova Iorque: ACM, 1992, p.28-28. 


\section{Apêndice A}

Nesta seção, são apresentadas na Tabela 18 informações sobre os artigos selecionados na Revisão Sistemática (Seção 2).

Tabela 18: Artigos selecionados na revisão sistemática.

\begin{tabular}{|c|c|c|c|}
\hline Título & Autores & Jornal/Conferência & Ano \\
\hline $\begin{array}{l}\text { 1.Physical query interface for } \\
\text { tangible augmented tagging } \\
\text { and interaction }\end{array}$ & $\begin{array}{l}\text { Dong Woo Seo, Jae } \\
\text { Yeol Lee }\end{array}$ & $\begin{array}{l}\text { Expert Systems with } \\
\text { Applications, v.40, n.6, } \\
\text { mar.2013 }\end{array}$ & 2013 \\
\hline $\begin{array}{l}\text { 2.PneUI: Pneumatically } \\
\text { Actuated Soft Composite } \\
\text { Materials for Shape } \\
\text { Changing Interfaces }\end{array}$ & $\begin{array}{l}\text { Lining Yao, L., } \\
\text { Ryuma, N., Ou,J., } \\
\text { Follmer, S., Della } \\
\text { Silva, C., Ishi, H. }\end{array}$ & $\begin{array}{l}\text { Proceedings of the } 26 \text { th } \\
\text { annual ACM } \\
\text { symposium on User } \\
\text { interface software and } \\
\text { technology (UIST' } 13 \text { ) }\end{array}$ & 2013 \\
\hline $\begin{array}{l}\text { 3. Empowering materiality: } \\
\text { inspiring the design of } \\
\text { tangible interactions }\end{array}$ & $\begin{array}{l}\text { Magdalena Schmid, } \\
\text { Sonja Rümelin, } \\
\text { Hendrik Richter }\end{array}$ & $\begin{array}{l}\text { Proceedings of the } 7 \text { th } \\
\text { International } \\
\text { Conference on Tangible } \\
\text { (TEI '13), Embedded } \\
\text { and Embodied } \\
\text { Interaction, Fev } 2013\end{array}$ & 2013 \\
\hline $\begin{array}{l}\text { 4.Exploring tangible } \\
\text { collaborative distance } \\
\text { learning environments for } \\
\text { the blind and visually } \\
\text { impaired }\end{array}$ & $\begin{array}{l}\text { Muhanad S. Manshad, } \\
\text { Enrico Pontelli, } \\
\text { Shakir J. Manshad }\end{array}$ & $\begin{array}{l}\text { CHI '13 Extended } \\
\text { Abstracts on Human } \\
\text { Factors in Computing } \\
\text { Systems, abr } 2013\end{array}$ & 2013 \\
\hline $\begin{array}{l}\text { 5. To TUI or not to TUI: } \\
\text { Evaluating performance and } \\
\text { preference in tangible vs. } \\
\text { graphical user interfaces }\end{array}$ & $\begin{array}{l}\text { Oren Zuckermann, } \\
\text { Ayelet Gal-Oz, }\end{array}$ & $\begin{array}{l}\text { International Journal of } \\
\text { Human-Computer } \\
\text { Studies, v.71, n.7-8, } \\
\text { jul. } 2013\end{array}$ & 2013 \\
\hline $\begin{array}{l}\text { 6. Towards a more flexible and } \\
\text { creative music mixing } \\
\text { interface }\end{array}$ & $\begin{array}{l}\text { Steven Gelineck, } \\
\text { Morten Büchert, } \\
\text { Jesper Andersen }\end{array}$ & $\begin{array}{l}\text { CHI '13 Extended } \\
\text { Abstracts on Human } \\
\text { Factors in Computing } \\
\text { Systems, abr } 2013\end{array}$ & 2013 \\
\hline $\begin{array}{l}\text { 7. Tangible versus graphical } \\
\text { user interfaces for robot } \\
\text { programming: exploring } \\
\text { cross-age children's } \\
\text { preferences }\end{array}$ & $\begin{array}{l}\text { Theodosios } \\
\text { Sapounidis, Stavros } \\
\text { Demetriadis }\end{array}$ & $\begin{array}{l}\text { Personal and } \\
\text { Ubiquitous Computing, } \\
\text { v.17, n. } 8,2013\end{array}$ & 2013 \\
\hline $\begin{array}{l}\text { 8. Codein-A New Notation } \\
\text { for GOMS to Handle } \\
\text { Evaluations of Reality- } \\
\text { Based Interaction Style } \\
\text { Interfaces }\end{array}$ & $\begin{array}{l}\text { Christou, Georgios; } \\
\text { Ritter, Frank E.; } \\
\text { Jacob, Robert J. K. }\end{array}$ & $\begin{array}{l}\text { International Journal of } \\
\text { Human-Computer } \\
\text { Interaction, v.28, n.3, } \\
2012\end{array}$ & 2012 \\
\hline
\end{tabular}




\begin{tabular}{|c|c|c|c|}
\hline $\begin{array}{c}\text { Título } \\
\end{array}$ & Autores & Jornal/Conferência & Ano \\
\hline $\begin{array}{l}\text { 9.Prototipação de interfaces } \\
\text { tangíveis de produtos } \\
\text { interativos: estado da arte e } \\
\text { desafios da plataforma } \\
\text { arduino }\end{array}$ & $\begin{array}{l}\text { Gabriel Alves } \\
\text { Vasiljevic Mendes, } \\
\text { Leonardo Cunha de } \\
\text { Miranda, Erica } \\
\text { Esteves Cunha de } \\
\text { Miranda, Lyrene } \\
\text { Fernandes da Silva }\end{array}$ & $\begin{array}{l}\text { Proceedings of the 11th } \\
\text { Brazilian Symposium } \\
\text { on Human Factors in } \\
\text { Computing Systems } \\
\text { (IHC '12), } 2012\end{array}$ & 2012 \\
\hline $\begin{array}{l}\text { 10. Exploring material- } \\
\text { centered design concepts for } \\
\text { tangible interaction }\end{array}$ & $\begin{array}{l}\text { Tanja Döring, Axel } \\
\text { Sylvester, Albrecht } \\
\text { Schmidt }\end{array}$ & $\begin{array}{l}\text { Proceedings of the } \\
2012 \text { ACM annual } \\
\text { conference extended } \\
\text { abstracts on Human } \\
\text { Factors in Computing } \\
\text { Systems Extended } \\
\text { Abstracts (CHI EA } \\
\text { '12), mai } 2012\end{array}$ & 2012 \\
\hline $\begin{array}{l}\text { 11. SoloFind: chains of } \\
\text { interactions with a mobile } \\
\text { retail experience system }\end{array}$ & $\begin{array}{l}\text { Alexander Wiethoff, } \\
\text { Gregor Broll }\end{array}$ & $\begin{array}{l}\text { CHI '11 Extended } \\
\text { Abstracts on Human } \\
\text { Factors in Computing } \\
\text { Systems (CHI EA '11), } \\
2011\end{array}$ & 2011 \\
\hline $\begin{array}{l}\text { 12. Material-Centered Design } \\
\text { and Evaluation of Tangible } \\
\text { User Interfaces }\end{array}$ & Döring, Tanja & $\begin{array}{l}\text { 5th International } \\
\text { Conference on } \\
\text { Tangible, Embedded } \\
\text { and Embodied } \\
\text { Interaction (TEI'11), } \\
2011\end{array}$ & 2011 \\
\hline $\begin{array}{l}\text { 13. Rope Revolution: tangible } \\
\text { and gestural rope interface } \\
\text { for collaborative play }\end{array}$ & $\begin{array}{l}\text { Lining Yao, } \\
\text { Sayamindu Dasgupta, } \\
\text { Nadia Cheng, Jason } \\
\text { Spingarn-Koff, Ostap } \\
\text { Rudakevych, Hiroshi } \\
\text { Ishii }\end{array}$ & $\begin{array}{l}\text { Proceedings of the 8th } \\
\text { International } \\
\text { Conference on } \\
\text { Advances in Computer } \\
\text { Entertainment } \\
\text { Technology (ACE '11), } \\
2011\end{array}$ & 2011 \\
\hline $\begin{array}{l}\text { 14. Bosu: a physical } \\
\text { programmable design tool } \\
\text { for transformability with } \\
\text { soft mechanics }\end{array}$ & $\begin{array}{l}\text { Amanda Parkes, } \\
\text { Hiroshi Ishii }\end{array}$ & $\begin{array}{l}\text { Proceedings of the } 8 \text { th } \\
\text { ACM Conference on } \\
\text { Designing Interactive } \\
\text { Systems (DIS'10), abr } \\
2010\end{array}$ & 2010 \\
\hline $\begin{array}{l}\text { 15.Designing for the } \\
\text { unexpected: the role of } \\
\text { creative group work for } \\
\text { emerging interaction } \\
\text { design paradigms }\end{array}$ & $\begin{array}{l}\text { Chun-Ko Hsieh, I- } \\
\text { Ling Liu, Neng-Hao } \\
\text { Yu, Yueh-Hsuan } \\
\text { Chiang, Hsiang-Tao } \\
\text { Wu, Ying-Jui Chen, } \\
\text { Yi-Ping Hung }\end{array}$ & $\begin{array}{l}\text { MM '10: Proceedings } \\
\text { of the international } \\
\text { conference on } \\
\text { Multimedia, p.1453- } \\
1456\end{array}$ & 2010 \\
\hline $\begin{array}{l}\text { 16.Graspables revisited: } \\
\text { multi-touch vs. tangible } \\
\text { input for tabletop displays } \\
\text { in acquisition and } \\
\text { manipulation tasks }\end{array}$ & $\begin{array}{l}\text { Philip Tuddenham, } \\
\text { David Kirk, Shahram } \\
\text { Izadi }\end{array}$ & $\begin{array}{l}\text { Proceedings of the } \\
\text { SIGCHI Conference on } \\
\text { Human Factors in } \\
\text { Computing Systems } \\
\text { (CHI '10), } 2010\end{array}$ & 2010 \\
\hline
\end{tabular}




\begin{tabular}{|c|c|c|c|}
\hline $\begin{array}{c}\text { Título } \\
\end{array}$ & Autores & Jornal/Conferência & Ano \\
\hline $\begin{array}{l}\text { 17. Design by physical } \\
\text { composition for complex } \\
\text { tangible user interfaces }\end{array}$ & $\begin{array}{l}\text { Tanja Döring, Bastian } \\
\text { Pfleging, Christian } \\
\text { Kray, Albrecht } \\
\text { Schmidt }\end{array}$ & $\begin{array}{l}\text { CHI '10 Extended } \\
\text { Abstracts on Human } \\
\text { Factors in Computing } \\
\text { Systems (CHI EA '10), } \\
2010\end{array}$ & 2010 \\
\hline $\begin{array}{l}\text { 18. Stop-motion prototyping } \\
\text { for tangible interfaces }\end{array}$ & $\begin{array}{l}\text { Bonanni, L. and Ishii, } \\
\text { H. }\end{array}$ & $\begin{array}{l}\text { Proceedings of the 3rd } \\
\text { international } \\
\text { Conference on Tangible } \\
\text { and Embedded } \\
\text { interaction (TEI '09), } \\
2009\end{array}$ & 2009 \\
\hline $\begin{array}{l}\text { 19. Activity theory and the } \\
\text { practice of design: } \\
\text { Evaluation of a } \\
\text { collaborative tangible user } \\
\text { interface }\end{array}$ & $\begin{array}{l}\text { Fjeld, M.; Morf, M.; } \\
\text { Krueger, H. }\end{array}$ & $\begin{array}{l}\text { Behavior Research } \\
\text { Methods. Volume: } 41 \\
\text { Issue: } 4 \text { Pages: } 1272- \\
1272\end{array}$ & 2009 \\
\hline $\begin{array}{l}\text { 20. A specification paradigm } \\
\text { for the design and } \\
\text { implementation of tangible } \\
\text { user interfaces }\end{array}$ & $\begin{array}{l}\text { Orit Shaer, Robert } \\
\text { J.K. Jacob }\end{array}$ & $\begin{array}{l}\text { Transactions on } \\
\text { Computer-Human } \\
\text { Interaction (TOCHI) } \\
\text { v.16, n.4, nov. } 2009\end{array}$ & 2009 \\
\hline $\begin{array}{l}\text { 21.TUI interactive product } \\
\text { design }\end{array}$ & $\begin{array}{l}\text { Qin Jingyan; Guan } \\
\text { Yan; Ji Huiwen }\end{array}$ & $\begin{array}{l}\text { Proceedings of the } \\
\text { IEEE 10th International } \\
\text { Conference on } \\
\text { Computer-Aided } \\
\text { Industrial Design \& } \\
\text { Conceptual Design, } \\
2009 .\end{array}$ & 2009 \\
\hline $\begin{array}{l}\text { 22. Designing for the } \\
\text { unexpected: the role of } \\
\text { creative group work for } \\
\text { emerging interaction } \\
\text { design paradigms }\end{array}$ & $\begin{array}{l}\text { Antti Pirhonen e } \\
\text { Emma Murphy }\end{array}$ & $\begin{array}{l}\text { Visual Communication, } \\
\text { Volume: } 7 \text { N. } 3 \\
\text { Páginas: } 331-344 \text {. Aug } \\
2008\end{array}$ & 2008 \\
\hline $\begin{array}{l}\text { 23. Do the blocks rock: a } \\
\text { tangible interface for play } \\
\text { and exploration }\end{array}$ & Frank G. Feltham & $\begin{array}{l}\text { Proceedings of the 20th } \\
\text { Australasian } \\
\text { Conference on } \\
\text { Computer-Human } \\
\text { Interaction: Designing } \\
\text { for Habitus and Habitat } \\
\text { (OZCHI '08), dez. } 2008\end{array}$ & 2008 \\
\hline $\begin{array}{l}\text { 24. Translation and rotation of } \\
\text { virtual objects in } \\
\text { Augmented Reality: A } \\
\text { comparison of interaction } \\
\text { devices }\end{array}$ & $\begin{array}{l}\text { Reifinger, S.; Laquai, } \\
\text { F.; Rigoll, G. }\end{array}$ & $\begin{array}{l}\text { Proceedings of the } \\
\text { IEEE International } \\
\text { Conference on } \\
\text { Systems, Man and } \\
\text { Cybernetics, (SMC } \\
\text { 2008), 2008 }\end{array}$ & 2008 \\
\hline $\begin{array}{l}\text { 25.The ColorTable: a design } \\
\text { story }\end{array}$ & $\begin{array}{l}\text { Valérie Maquil, } \\
\text { Thomas Psik, Ina } \\
\text { Wagner }\end{array}$ & $\begin{array}{l}\text { Proceedings of the } 2 \text { nd } \\
\text { international } \\
\text { conference on Tangible } \\
\text { and embedded } \\
\text { interaction (TEI '08), } \\
2008\end{array}$ & 2008 \\
\hline
\end{tabular}




\begin{tabular}{|c|c|c|c|}
\hline $\begin{array}{c}\text { Título } \\
\end{array}$ & Autores & Jornal/Conferência & Ano \\
\hline $\begin{array}{l}\text { 26. Designing and testing a } \\
\text { tangible interface } \\
\text { prototype }\end{array}$ & $\begin{array}{l}\text { Diana Xu, Janet C } \\
\text { Read, Emanuela } \\
\text { Mazzone, Martin } \\
\text { Brown }\end{array}$ & $\begin{array}{l}\text { Proceedings of the 6th } \\
\text { international } \\
\text { conference on } \\
\text { Interaction design and } \\
\text { children (IDC '07), jun } \\
2007\end{array}$ & 2007 \\
\hline $\begin{array}{l}\text { 27. Towards a new method for } \\
\text { the evaluation of reality } \\
\text { based interaction }\end{array}$ & Georgios Christou & $\begin{array}{l}\text { CHI '07 Extended } \\
\text { Abstracts on Human } \\
\text { Factors in Computing } \\
\text { Systems (CHI EA '07), } \\
2007\end{array}$ & 2007 \\
\hline $\begin{array}{l}\text { 28. Ubiquitous computing to } \\
\text { support co-located clinical } \\
\text { teams: Using the semiotics } \\
\text { of physical objects in } \\
\text { system design }\end{array}$ & $\begin{array}{l}\text { Magnus Banga e } \\
\text { Toomas Timpkaa }\end{array}$ & $\begin{array}{l}\text { International Journal of } \\
\text { Medical Informatics } \\
\text { Volume 76, 1, June } \\
\text { 2007, Pages S58-S64 }\end{array}$ & 2007 \\
\hline $\begin{array}{l}\text { 29. InterCUBE: A study into } \\
\text { merging action and } \\
\text { interaction spaces }\end{array}$ & $\begin{array}{l}\text { Salem, Benjamin; } \\
\text { Peeters, Harold }\end{array}$ & $\begin{array}{l}\text { Proceedings of the } 11 \text { th } \\
\text { IFIP International } \\
\text { Conference on Human- } \\
\text { Computer Interaction, } \\
2007\end{array}$ & 2007 \\
\hline $\begin{array}{l}\text { 30. Correlates of the cognitive } \\
\text { dimensions for tangible } \\
\text { user interface }\end{array}$ & $\begin{array}{l}\text { Darren Edge, Alan } \\
\text { Blackwell }\end{array}$ & $\begin{array}{l}\text { Journal of Visual } \\
\text { Languages \& } \\
\text { Computing, v. 17, n. 4, } \\
\text { ago } 2006\end{array}$ & 2006 \\
\hline $\begin{array}{l}\text { 31. In search for evaluation } \\
\text { methods for children's } \\
\text { tangible technology }\end{array}$ & $\begin{array}{l}\text { Diana Xu, Emanuela } \\
\text { Mazzone, Stuart } \\
\text { MacFarlane }\end{array}$ & $\begin{array}{l}\text { Proceedings of the } \\
2006 \text { conference on } \\
\text { Interaction design and } \\
\text { children (IDC '06), } \\
2006\end{array}$ & 2006 \\
\hline $\begin{array}{l}\text { 32. Exploration and reflection } \\
\text { in interactive art: glass } \\
\text { pond }\end{array}$ & $\begin{array}{l}\text { Jennifer Seevinck, } \\
\text { Linda Candy, Ernest } \\
\text { A. Edmonds }\end{array}$ & $\begin{array}{l}\text { Proceedings of the } 18 \text { th } \\
\text { Australia conference on } \\
\text { Computer-Human } \\
\text { Interaction: Design: } \\
\text { Activities, Artefacts } \\
\text { and Environments } \\
\text { (OZCHI '06), } 2006\end{array}$ & 2006 \\
\hline $\begin{array}{l}\text { 33. Designing a wearable user } \\
\text { interface for hands-free } \\
\text { interaction in maintenance } \\
\text { applications }\end{array}$ & $\begin{array}{l}\text { Witt, H.; Nicolai, T.; } \\
\text { Kenn, H. }\end{array}$ & $\begin{array}{l}\text { Fourth Annual IEEE } \\
\text { International } \\
\text { Conference on } \\
\text { Pervasive Computing } \\
\text { and Communications } \\
\text { Workshops, } 2006\end{array}$ & 2006 \\
\hline $\begin{array}{l}\text { 34. The Webkit tangible user } \\
\text { interface: a case study of } \\
\text { iterative prototyping }\end{array}$ & $\begin{array}{l}\text { Stringer, M.; Rode, } \\
\text { J.A.; Toye, E.F.; } \\
\text { Blackwell, A.F.; } \\
\text { Simpson, A.R. }\end{array}$ & $\begin{array}{l}\text { IEEE Pervasive } \\
\text { Computing, v.4, n.4, } \\
2005\end{array}$ & 2005 \\
\hline $\begin{array}{l}\text { 35. Not just intuitive: } \\
\text { examining the basic } \\
\text { manipulation of tangible } \\
\text { user interfaces }\end{array}$ & Chen-Je Huang & $\begin{array}{l}\text { April } 2004 \text { CHI EA } \\
\text { '04: CHI '04 Extended } \\
\text { Abstracts on Human } \\
\text { Factors in Computing } \\
\text { Systems }\end{array}$ & 2004 \\
\hline
\end{tabular}




\begin{tabular}{|c|c|c|c|}
\hline $\begin{array}{c}\text { Título } \\
\end{array}$ & Autores & Jornal/Conferência & Ano \\
\hline $\begin{array}{l}\text { 36. On tangible user interfaces, } \\
\text { humans and spatiality }\end{array}$ & $\begin{array}{l}\text { Ehud Sharlin, } \\
\text { Benjamin Watson, } \\
\text { Yoshifumi Kitamura, } \\
\text { Fumio Kishino, } \\
\text { Yuichi Itoh } \\
\end{array}$ & $\begin{array}{l}\text { September } 2004 \\
\text { Personal and } \\
\text { Ubiquitous Computing } \\
\text {, Volume } 8 \text { Issue } 5\end{array}$ & 2004 \\
\hline $\begin{array}{l}\text { 37. Bringing Clay and Sand } \\
\text { into Digital Design - } \\
\text { Continuous Tangible user } \\
\text { Interfaces }\end{array}$ & $\begin{array}{l}\text { Ishii, H., Ratti, C., } \\
\text { Piper, B., Wang, Y., } \\
\text { Biderman, A., and } \\
\text { Ben-Joseph, E. }\end{array}$ & $\begin{array}{l}\text { BT Technology } \\
\text { Journal, v.22, n. } 4 \text {, oct. } \\
2004\end{array}$ & 2004 \\
\hline $\begin{array}{l}\text { 38. Interaction frogger: a } \\
\text { design framework to } \\
\text { couple action and function } \\
\text { through feedback and } \\
\text { feedforward }\end{array}$ & $\begin{array}{l}\text { S. A. G. Wensveen, J. } \\
\text { P. Djajadiningrat, C. } \\
\text { J. Overbeeke }\end{array}$ & $\begin{array}{l}\text { Proceedings of the } 5 \text { th } \\
\text { conference on } \\
\text { Designing interactive } \\
\text { systems: processes, } \\
\text { practices, methods, and } \\
\text { techniques (DIS '04), } \\
2004\end{array}$ & 2004 \\
\hline
\end{tabular}




\section{Apêndice $B$}

Nesta seção, é apresentado o Formulário de Metamensagem com as informações preenchidas pelo grupo participante do estudo na etapa de Prototipação da Forma, como descrito na Seção 5.2.

\section{FORMULÁRIO DE METAMENSAGEM}

\begin{tabular}{ll}
$\begin{array}{ll}\text { Quem é o } \\
\text { usuário? }\end{array}$ & Os destinatários do convite de festa de aniversário, entre 18 e \\
\cline { 2 - 2 } $\begin{array}{l}\text { On anos. } \\
\text { Oue ele quer } \\
\text { ou precisa } \\
\text { fazer? }\end{array}$ & \begin{tabular}{l} 
Precisa obter informações para poder ir à festa de aniversário. \\
\cline { 2 - 2 }
\end{tabular} \\
\cline { 2 - 2 } $\begin{array}{l}\text { De que } \\
\text { maneira ele } \\
\text { prefere fazê-lo } \\
\text { e por quê? }\end{array}$ & Prefere interagir e usar ludicamente o convite porque é mais \\
\cline { 2 - 2 } &
\end{tabular}

Qual o sistema É um convite pop-up que usa QR Codes para interagir com o projetado? usuário. Também usa música e leds para chamar a atenção do usuário para o tema da festa (super-heróis).

De que forma Quando o convite é aberto, leds são ligados nos balões ele pode ou deve ser utilizado? (contidos na imagem de fundo) e nos olhos da boneca pop-up. Também é tocada a música "Little Bad Girl". O usuário pode:

- Tirar a máscara que mostra o nome da aniversariante.

- Puxar a parte que mostra o mapa impresso em QR Code que seleciona o Google Maps.

- Soprar o balão com QR Code com o Google Calendar (data e hora).

- Escolher um dos QR Codes para RSVP. 


\section{Apêndice $C$}

Neste anexo se encontra descrito o formulário utilizado como base para as avaliações dos testes de usuário nas etapas de Prototipação da Forma e Prototipação do Artefato.

\section{Formulário de Avaliação}

\section{Protótipo:}

Etapa:

Teste $\mathbf{n}^{0}$ :

\section{Usuário:}

\section{Data:}

\section{Observações}

<registrar as observações do grupo que possam ser relevantes para a discussão sobre o teste>

\section{Comentários do usuário}

$<$ registrar os comentários do usuário que possam ser relevantes para a discussão sobre o teste>

\section{Modificações indicadas}

$<$ relacionar as modificações a serem implementadas na próxima versão do protótipo definidas pelo grupo $>$

\section{Recomendações relativas ao protótipo para iterações ou etapas seguintes}

$<$ relacionar as recomendações relativas ao desenvolvimento do protótipo que sejam relevantes para o desenvolvimento do trabalho de prototipação> 


\section{Apêndice D}

Este anexo apresenta um resumo sobre os comentários dos designers acerca dos benefícios percebidos na incorporação de conceitos da Engenharia Semiótica no projeto de tangíveis, como proposto no método de Prototipação Colaborativa de Tangíveis Baseada na Engenharia Semiótica, relatados durante as entrevistas individuais. A Tabela 19 apresenta trechos dos comentários selecionados.

Tabela 19: Benefícios percebidos pelos participantes.

\begin{tabular}{|c|l|}
\hline Participante & \multicolumn{1}{c|}{ Benefícios relatados } \\
\hline D1 & $\begin{array}{l}\text { "Não percebi muito a diferença. Acho que o processo foi muito parecido } \\
\text { com o que a gente já fez... O uso de formulários (de avaliação) e um } \\
\text { checklist (trechos da metamensagem) possibilita comparar a } \\
\text { metamensagem criada no início com a avaliação ao final." }\end{array}$ \\
\hline "A primeira coisa é a seguinte: como eu escrevi a mensagem \\
(metamensagem), eu quero ver se a pessoa entendeu a mensagem. Eu \\
nunca sequer tinha pensado nisso... O fato de ter um método que diga \\
pra fazer dessa maneira nos coloca atentos à questão da mensagem, se \\
está passando... Eu, particularmente, pra mim foi uma coisa nova que eu \\
não estava acostumado a olhar e pra mim tudo que é novo e me ajuda a \\
entender melhor como o meu usuário vai usar aquela tecnologia, que \\
tipo de problema tem, pra mim é útil. Então foi útil entender a \\
mensagem. Se é a melhor coisa do mundo, se isso prejudica outras \\
coisas que deveriam ser olhadas, eu não sei... Talvez isso esteja \\
mascarando outras coisas, mas, por exemplo, não mascarou a questão da \\
dificuldade tecnológica...
\end{tabular}




\begin{tabular}{|c|l|}
\hline Participante & \multicolumn{1}{c|}{ Benefícios relatados } \\
\hline \multirow{5}{*}{ D4 } & $\begin{array}{l}\text { "Os formulários ajudam na documentação do projeto, das etapas, e nos } \\
\text { logs das propostas. Se a gente mudou, não mudou, se a gente } \\
\text { acompanhou o que a gente escreveu no início. Muita coisa que a gente } \\
\text { escreveu no início depois a gente não fez, a gente mudou na hora. Ajuda } \\
\text { como um guia de referência do que a gente foi pensando e o que a gente } \\
\text { foi mudando depois." }\end{array}$ \\
\hline & $\begin{array}{l}\text { "(Usar a metamensagem na avaliação) Foi muito útil porque conforme a } \\
\text { gente vai construindo perde um pouco da objetividade... como são } \\
\text { muitas ideias, como são muitas soluções pra problemas que vão } \\
\text { aparecendo no caminho, às vezes a gente se esquece um pouco qual era a } \\
\text { proposta original... A avaliação ficou um pouco mais objetiva... Ficou } \\
\text { mais fácil de avaliar o que realmente se entende daquilo que foi } \\
\text { construído." }\end{array}$ \\
\cline { 2 - 3 } \\
$\begin{array}{l}\text { "Quando todo mundo senta pra fazer a metamensagem e acorda aquela } \\
\text { metamensagem, traz o grupo de novo pra uma ideia comum." }\end{array}$ \\
\cline { 2 - 3 } \\
$\begin{array}{l}\text { "O formulário (da metamensagem) ajudou a manter as ideias originais } \\
\text { do projeto até a construção final do protótipo... Se deixasse solto, era } \\
\text { capaz da gente ter seguindo um caminho bem diferente do que tinha sido } \\
\text { proposto pelo grupo no início... Facilita num processo de } \\
\text { documentação." }\end{array}$ \\
\hline
\end{tabular}

Os benefícios relatados podem ser resumidos nos itens relacionados a seguir. Nota-se que os itens 1 a 3 são relativos aos conceitos fundamentais de Engenharia Semiótica em si (foco na comunicabilidade, metamensagem), enquanto os itens 4 a 8 se referem à aplicação destes conceitos no escopo do método proposto (formulário, forma de avaliação da interface):

1. O foco do projeto é comunicabilidade da interface (D2);

2. A metamensagem é um meio de registro das ideias do projeto (D4);

3. O foco da avaliação é a comunicabilidade da interface (D1, D2, D3 e D4);

4. A metamensagem orienta a avaliação dos testes com usuário (D1 e D3);

5. A avaliação com base na metamensagem é mais objetiva (D4);

6. O Formulário de Metamensagem orienta todo o projeto (D2);

7. O Formulário de Metamensagem orienta a avaliação dos testes com usuário (D3);

8. O Formulário de Metamensagem é um meio de documentação do projeto (D3 e D4). 